\title{
ESTUDO DO EFEITO RADIOPROTETOR DO RESVERATROL
}

\author{
CAROLINA DOS SANTOS MORENO
}

Dissertação apresentada como parte dos requisitos para obtenção do Grau de Mestre em Ciências na Área de Tecnologia Nuclear - Aplicações.

Orientador:

Dr. José Roberto Rogero 
INSTITUTO DE PESQUISAS ENERGÉTICAS E NUCLEARES

Autarquia associada à Universidade de São Paulo

\title{
ESTUDO DO EFEITO RADIOPROTETOR DO RESVERATROL
}

\author{
CAROLINA DOS SANTOS MORENO
}

Dissertação apresentada como parte dos requisitos para obtenção do Grau de Mestre em Ciências na Área de Tecnologia Nuclear - Aplicações.

Orientador:

Dr. José Roberto Rogero

São Paulo 
Dedico este trabalho à minha família, em especial à minha mãe e amiga Miriam Ap. Cardoso dos Santos. 


\section{AGRADECIMENTOS}

Ao Dr. José Roberto Rogero, pelo enorme apoio, incentivo, presença em todas as dificuldades, confiança e orientação concedidos ao longo da realização deste trabalho.

À Ms. Sizue O. Rogero, pela preciosa ajuda e apoio na realização e interpretação de dados dos testes biológicos.

Ao Dr. Ademar B. Lugão, pelo acolhimento, proporcionando condições laboratoriais necessárias para a realização deste trabalho.

À Dra. Áurea S. Cruz pelo fornecimento dos materiais biológicos e pelas valiosas sugestões.

À Elizabeth S.R. Somessari e Carlos G. da Silveira pela enorme atenção dispensada durante os processos de irradiação.

Ao Dr. Patrick J. Spencer pelo grande apoio e atenção concedidos.

Ao Roberto M. Leon Filho e Romulo dos S. Moreno pelo incentivo e apoio.

À Renata H. Amaral pelo auxílio no transporte dos materiais biológicos.

À equipe da Seção de Culturas Celulares do Instituto Adolfo Lutz, pela atenção concedida.

Aos colegas de laboratório e de sala de aula, pelo companheirismo.

Ao IPEN/CNEN pela infra-estrutura oferecida. 


\title{
ESTUDO DO EFEITO RADIOPROTETOR DO RESVERATROL
}

\author{
Carolina dos Santos Moreno
}

\section{RESUMO}

Resveratrol (3,4',5-trihidroxiestilbeno), um polifenol pertencente ao grupo de compostos denominados fitoalexinas, é sintetizado por uma ampla variedade de plantas, tais como as videiras, em resposta a infecções fúngicas e a exposição à radiação UV. Nos vinhos este composto está presente em elevadas concentrações, sendo considerado um dos constituintes com maior potencial antioxidante. Esta elevada capacidade de absorver os radicais livres presentes em diversos processos biológicos permite ao resveratrol previnir doenças cardiovasculares e diversos tipos de câncer. O principal objetivo do presente estudo foi determinar in vitro o efeito radioprotetor do resveratrol em cultura celular com auxílio dos testes de citotoxicidade do resveratrol $\left(\mathrm{IC}_{50 \%}\right)$ e da dose letal $50 \%$ da radiação gama $\left(\mathrm{DL}_{50}\right)$. Os estudos in vitro do nível de toxicidade do resveratrol, verificado pelo ensaio de citotoxicidade utilizando-se o método de incorporação do vermelho neutro, e da determinação da dose letal $50 \%\left(\mathrm{DL}_{50}\right)$ da radiação gama, oriunda de uma fonte de Cobalto-60 (Co-60), foram realizados em cultura de células da linhagem NCTC Clone 929 da ATCC. O IC $50 \%$ do resveratrol foi de aproximadamente $50 \mu \mathrm{M} / \mathrm{L}$. A $D_{50}$ da radiação gama apresentou um valor de aproximadamente 354 Gy. Baseando-se nestes resultados biológicos foram realizados estudos do efeito radioprotetor do resveratrol nas mesmas condições experimentais, constatando-se que o resveratrol nas concentrações entre 12,5 $\mu \mathrm{M} / \mathrm{L}$ e $25 \mu \mathrm{M} / \mathrm{L}$ apresentou um efeito radioprotetor mais acentuado. 


\title{
STUDY OF RADIOPROTECTIVE EFFECT OF THE RESVERATROL
}

\author{
Carolina dos Santos Moreno
}

\begin{abstract}
Resveratrol (3,4',5 trihydroxystilbene), a phenolic phytoalexin occurring naturally in a wide variety of plants, such as grapevines, in response to injury as fungal infections and exposure to ultraviolet light. In the wines this compound is present at high levels and is considered one of the higest antioxidant constituents. This high capacity to scavenge the free radicals generated by several biologic processes by resveratrol can provide a prevention of human cardiovascular diseases and several types of cancer. The main objective of this study was to determine the in vitro radioprotective effect of resveratrol in cell culture with the aid of the tests of cytotoxicity of resveratrol $\left(\mathrm{IC}_{50 \%}\right)$ and lethal dose $50 \%$ of gamma radiation $\left(\mathrm{LD}_{50}\right)$. Studies of the level of resveratrol toxicity, found by cytotoxicity test performed by neutral red uptake assay, and lethal dose $50 \%\left(\mathrm{LD}_{50}\right)$ of gamma radiation from source of Cobalt-60 (Co-60) was performed in cell culture NCTC Clone 929 from ATCC. The $\mathrm{IC}_{50 \%}$ of resveratrol was about $50 \mu \mathrm{M} / \mathrm{L}$. The $\mathrm{DL}_{50}$ of gamma radiation showed a value of about 354Gy. On the basis of these biological results, it was performed studies of radioprotective effect of resveratrol on the same experimental conditions, verifying that the resveratrol in concentrations between $12.5 \mu \mathrm{M} / \mathrm{L}$ and $25 \mu \mathrm{M} / \mathrm{L}$ showed a more pronounced radioprotective effect.
\end{abstract}




\section{SUMÁRIO}

\section{Página}

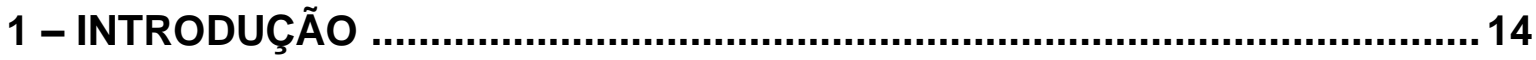

2 - OBJETIVO

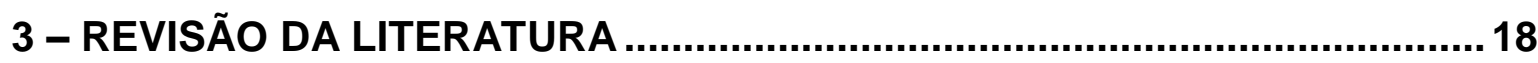

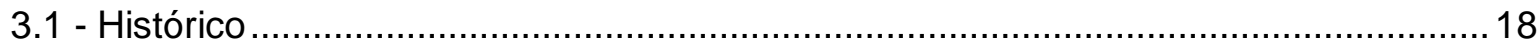

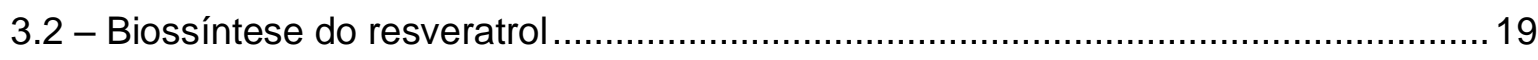

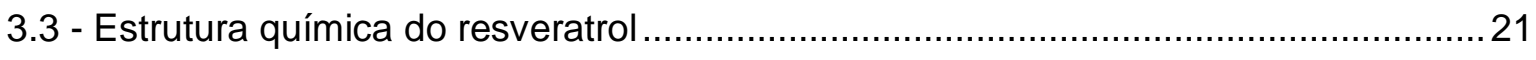

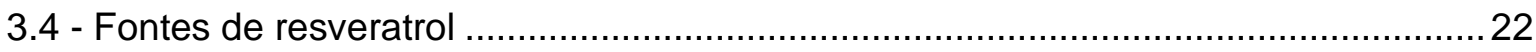

3.5 - Processos de absorção e distribuição do resveratrol pelo organismo vivo ................26

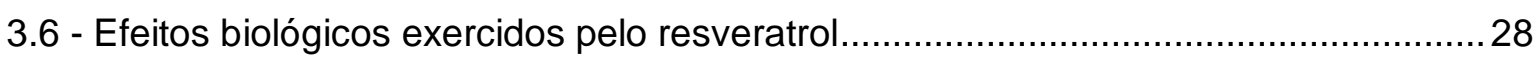

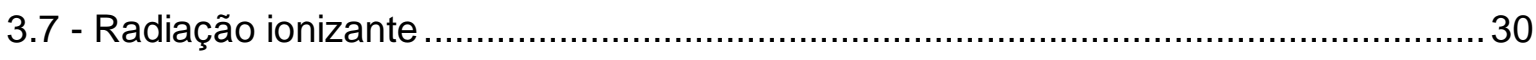

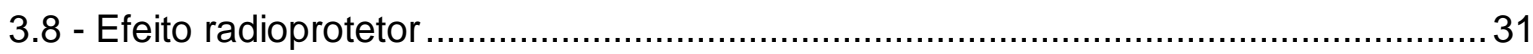

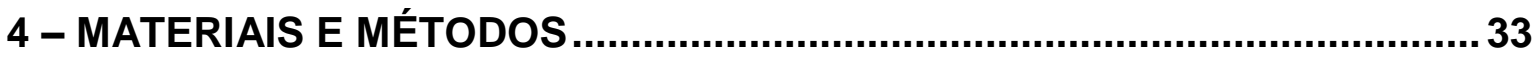

4.1 - Preparo das microplacas de cultura celular ............................................................. 33

4.2 - Determinação in vitro do índice de citotoxicidade $\left(\mathrm{IC}_{50 \%}\right)$ do resveratrol .....................35

4.3 - Determinação in vitro da dose letal $50 \%\left(\mathrm{DL}_{50}\right)$ da radiação gama ........................... 40

4.4 - Determinação in vitro do efeito radioprotetor do resveratrol .......................................4 43

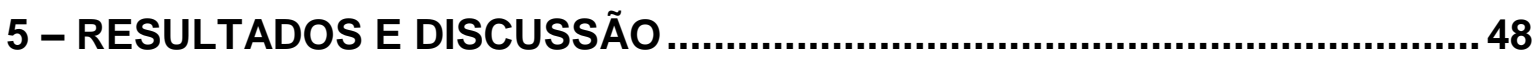

5.1 - Determinação in vitro do índice de citotoxicidade $\left(\mathrm{IC}_{50 \%}\right)$ do resveratrol ....................48

5.2 - Determinação in vitro da dose letal $50 \%\left(\mathrm{DL}_{50}\right)$ da radiação gama ...........................53

5.3 - Determinação in vitro do efeito radioprotetor do resveratrol ......................................63

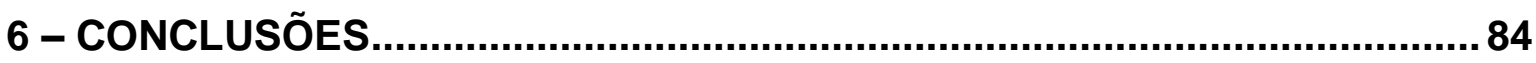

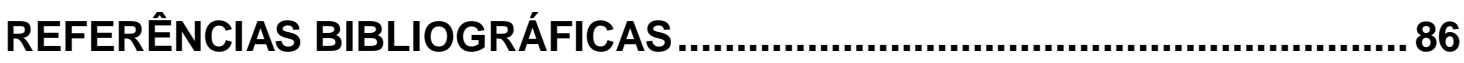




\section{LISTA DE TABELAS}

TABELA 1 - Médias das DO referentes às diferentes concentrações de resveratrol obtidas nos ensaios de citotoxicidade

TABELA 2 - Médias das DO referentes às diferentes concentrações do controle positivo obtidas nos ensaios de citotoxicidade do resveratrol

TABELA 3 - Médias das DO referentes às diferentes concentrações do controle negativo obtidas nos ensaios de citotoxicidade do resveratrol

TABELA 4 - Médias das DO e porcentagens de viabilidade celular referentes ao controle de células dos ensaios de citotoxicidade do resveratrol .... 49

TABELA 5 - Porcentagens de viabilidade celular referentes às diferentes concentrações de resveratrol obtidas no ensaio de citotoxicidade .. 50

TABELA 6 - Porcentagens de viabilidade celular referentes às diferentes concentrações do controle positivo obtidas no ensaio de citotoxicidade do resveratrol . .50

TABELA 7 - Porcentagens de viabilidade celular referentes às diferentes concentrações do controle negativo obtidas no ensaio de citotoxicidade do resveratrol. .51

TABELA 8 - Concentrações do resveratrol e dos extratos dos controles positivo e negativo e suas respectivas porcentagens de viabilidade celular obtidas pela média dos resultados apresentados pelos ensaios 1 e 2 de citotoxicidade do resveratrol. 
TABELA 9 - Médias das DO obtidas nas diferentes doses de radiação gama referentes aos ensaios realizados em cultura celular com densidade de $9,0 \times 10^{4}$ células/poço

TABELA 10 - Porcentagens de viabilidade celular obtidas nas diferentes doses de radiação gama referentes aos ensaios realizados em cultura celular com densidade de $9,0 \times 10^{4}$ células/poço 55

TABELA 11 - Médias das DO obtidas nas diferentes doses de radiação gama referentes aos ensaios do Grupo (A)

TABELA 12 - Médias das DO obtidas nas diferentes doses de radiação gama referentes ao ensaio do Grupo (B) 57

TABELA 13 - Médias das DO obtidas nas diferentes doses de radiação gama referentes aos ensaios do Grupo (C) 58

TABELA 14 - Porcentagens de viabilidade celular obtidas nas diferentes doses de radiação gama referentes aos ensaios do Grupo $(A)$

TABELA 15 - Porcentagens de viabilidade celular obtidas nas diferentes doses de radiação gama referentes ao ensaio do Grupo (B) 59

TABELA 16 - Porcentagens de viabilidade celular obtidas nas diferentes doses de radiação gama referentes aos ensaios do Grupo (C)

TABELA 17 - Médias das porcentagens de viabilidade celular obtidas nas diferentes doses de radiação gama referentes aos três grupos de ensaios 60

TABELA 18 - Médias das DO obtidas no ensaio 1 de radioproteção do resveratrol referente ao Grupo (A) 65 
TABELA 19 - Médias das DO obtidas no ensaio 2 de radioproteção do resveratrol referente ao Grupo (A)

TABELA 20 - Médias das DO obtidas no ensaio 3 de radioproteção do resveratrol referente ao Grupo (A) .66

TABELA 21 - Médias das DO obtidas no ensaio 4 de radioproteção do resveratrol referente ao Grupo (A) .67

TABELA 22 - Médias das DO obtidas no ensaio 5 de radioproteção do resveratrol referente ao Grupo (B) .67

TABELA 23 - Médias das DO obtidas no ensaio 6 de radioproteção do resveratrol referente ao Grupo $(\mathrm{C})$ 68

TABELA 24 - Médias das DO obtidas no ensaio 7 de radioproteção do resveratrol referente ao Grupo (D)

TABELA 25 - Médias das DO obtidas no ensaio 8 de radioproteção do resveratrol referente ao Grupo (D)

TABELA 26 - Porcentagens de viabilidade celular obtidas no ensaio 1 de radioproteção do resveratrol referente ao Grupo (A) .70

TABELA 27 - Porcentagens de viabilidade celular obtidas no ensaio 2 de radioproteção do resveratrol referente ao Grupo $(A)$ .70

TABELA 28 - Porcentagens de viabilidade celular obtidas no ensaio 3 de radioproteção do resveratrol referente ao Grupo (A) 71

TABELA 29 - Porcentagens de viabilidade celular obtidas no ensaio 4 de radioproteção do resveratrol referente ao Grupo (A) 71 
TABELA 30 - Porcentagens de viabilidade celular obtidas no ensaio 5 de radioproteção do resveratrol referente ao Grupo (B) .72

TABELA 31 - Porcentagens de viabilidade celular obtidas no ensaio 6 de radioproteção do resveratrol referente ao Grupo (C) .72

TABELA 32 - Porcentagens de viabilidade celular obtidas no ensaio 7 de radioproteção do resveratrol referente ao Grupo (D) .73

TABELA 33 - Porcentagens de viabilidade celular obtidas no ensaio 8 de radioproteção do resveratrol referente ao Grupo (D) .73

TABELA 34 - Médias das porcentagens de viabilidade celular obtidas no estudo do efeito radioprotetor do resveratrol referentes ao Grupo (A) 74

TABELA 35 - Médias das porcentagens de viabilidade celular obtidas no estudo do efeito radioprotetor do resveratrol referentes ao Grupo (D) .75

TABELA 36 - Médias das DO obtidas no estudo do efeito radioprotetor do resveratrol realizado em cultura de células em uma densidade de $5,0 \times 10^{4}$ células/poço .78

TABELA 37 - Porcentagens de viabilidade celular obtidas no estudo do efeito radioprotetor do resveratrol realizado em cultura de células em uma densidade de $5,0 \times 10^{4}$ células/poço

TABELA 38 - Médias das DO obtidas no estudo do efeito radioprotetor do resveratrol realizado em cultura de células em uma densidade de $2,0 \times 10^{4}$ células/poço 81

TABELA 39 - Porcentagens de viabilidade celular obtidas no estudo do efeito radioprotetor do resveratrol realizado em cultura de células em uma densidade de $2,0 \times 10^{4}$ células/poço .81 


\section{LISTA DE FIGURAS}

FIGURA 1 - Representação esquemática do processo de biossíntese do

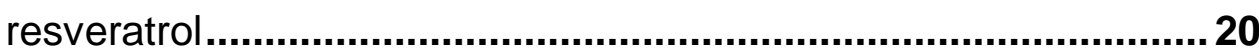

FIGURA 2 - Representação esquemática dos processos de síntese dos compostos derivados do resveratrol...............................................22

FIGURA 3 - Espécies de plantas com elevado potencial de síntese do resveratrol

FIGURA 4 - Fórmulas estruturais do resveratrol e dos estilbenos análogos presentes nos vinhos

FIGURA 5 - Monocamada de células da linhagem NCTC Clone 929, aumento $100 x$

FIGURA 6 - Microplaca de cultura celular contendo a linhagem de células NCTC Clone 929 em cultura

FIGURA 7 - Diluições em série efetuadas no fluxo laminar para a obtenção das soluções de resveratrol em diferentes concentrações 36

FIGURA 8 - Processo de esterilização das soluções de resveratrol 36

FIGURA 9 - Controles positivo e negativo utilizados no ensaio in vitro de citotoxicidade do resveratrol 37 
FIGURA 10 - Representação esquemática da distribuição das soluções de resveratrol, dos controles positivo, negativo e de células, nos poços da microplaca de cultura celular para a realização do teste de citotoxicidade do resveratrol

FIGURA 11 - Processo de lavagem da microplaca com PBS 39

FIGURA 12 - Leitura das DO em espectrofotômetro leitor tipo ELISA 40

FIGURA 13 - Irradiador GammaCell 200 41

FIGURA 14 - Montagem esquemática das fontes de Cobalto-60 contidas no irradiador GammaCell 200

FIGURA 15 - Distribuição das soluções de resveratrol nas microplacas de cultura celular para a determinação in vitro do efeito radioprotetor do composto 44

FIGURA 16 - Microplacas em estufa a $37^{\circ} \mathrm{C}$ e atmosfera com $5 \%$ de $\mathrm{CO}_{2}$ 45

FIGURA 17 - Curvas de viabilidade celular obtidas no ensaio in vitro de citotoxicidade do resveratrol 52

FIGURA 18 - Curva de viabilidade celular obtida no teste in vitro da $\mathrm{DL}_{50}$ da radiação gama referente aos ensaios realizados em cultura celular com densidade de $9,0 \times 10^{4}$ células/poço 56

FIGURA 19 - Curva de viabilidade celular obtida no estudo da $D L_{50}$ da radiação gama referente ao Grupo (A): Irradiação efetuada logo após a substituição do MEM contido nas microplacas por MEM suplementado com $5 \%$ de SFB 61 
FIGURA 20 - Curva de viabilidade celular obtida no estudo da $\mathrm{DL}_{50}$ da radiação gama referente ao Grupo (B): Irradiação efetuada logo após a substituição do MEM contido nas microplacas por PBS

FIGURA 21 - Curva de viabilidade celular obtida no estudo da $\mathrm{DL}_{50}$ da radiação gama referente ao Grupo (C): Irradiação das microplacas sem a substituição do MEM prévia a irradiação

FIGURA 22 - Curvas de viabilidade celular obtidas no estudo do efeito radioprotetor do resveratrol referente ao Grupo (A) .76

FIGURA 23 - Curvas de viabilidade celular obtidas no estudo do efeito radioprotetor do resveratrol referente ao Grupo (B) 76

FIGURA 24 - Curvas de viabilidade celular obtidas no estudo do efeito radioprotetor do resveratrol referente ao Grupo (C) .77

FIGURA 25 - Curvas de viabilidade celular obtidas no estudo do efeito radioprotetor do resveratrol referente ao Grupo (D) .77

FIGURA 26 - Curvas de viabilidade celular obtidas no estudo do efeito radioprotetor do resveratrol realizado em cultura de células em uma densidade de 5,0 $010^{4}$ células/poço 80

FIGURA 27 - Curvas de viabilidade celular obtidas no estudo do efeito radioprotetor do resveratrol realizado em cultura de células em uma densidade de 2,0 $\times 10^{4}$ células/poço 82 


\section{1 - INTRODUÇÃO}

Os indícios da existência do resveratrol remontam à época pré-romana, no entanto os processos de isolamento e caracterização desse composto foram realizados somente a partir do século XX (Pickeleman, 1990).

Resveratrol (3,4',5-trihidroxiestilbeno) é um polifenol pertencente ao conjunto de compostos denominados fitoalexinas (Jeandet et al., 2002). Este polifenol de defesa é sintetizado naturalmente por uma ampla variedade de plantas em resposta a exposição à radiação ultravioleta (UV) ou pelo estresse mecânico produzido pela ação de patógenos, agentes químicos e físicos (VanEtten et al., 1994).

Dentre as plantas que sintetizam o resveratrol, as videiras (Vitis vinifera e Vitis labrusca) são consideradas as espécies de elevada capacidade de síntese do composto (Frémont, 2000).

$\mathrm{Na}$ uva, a síntese do resveratrol ocorre na película do fruto em uma intensidade que reflete o nível de estresse sob o qual a videira é submetida (Pan et al., 2009). Nos vinhos, a concentração desta fitoalexina é relativamente elevada, principalmente no vinho tinto em decorrência do longo processo de maceração realizado durante a prática enológica. Os sucos de uva industrializados são considerados uma boa fonte de resveratrol para os abstêmios, embora a sua concentração seja inferior a dos vinhos (Sautter et al., 2005).

Na natureza, o resveratrol é encontrado nas formas isômeras: trans- e cis-resveratrol (3,4',5-trihidroxi-trans-estilbeno e 3,4',5-trihidroxi-cis-estilbeno) e em diversas formas análogas, dentre elas os isômeros trans- e cis-piceido (transresveratrol 3-O- $\beta$-glucoside e cis-resveratrol 3-O- $\beta$-glucoside). 0 isômero transresveratrol é comercializado no estado sólido e apresenta uma relativa estabilidade molecular, sendo convertido em isômero cis-resveratrol quando exposto a radiação UV (Goldberg et al., 1995b). Os isômeros trans- e cis-piceido apresentam uma estrutura química semelhante ao do resveratrol, porém glicosilada (Pezet et al., 2004). 
As intensas análises de caracterização e quantificação do resveratrol presente nos alimentos e em materiais biológicos evidenciaram as influências exercidas pelo composto em distintas atividades biológicas. Recentemente foi verificada uma tendência dos isômeros cis-resveratrol, trans- e cis-piceido em exercerem efeitos biológicos complementares ao do isômero trans-resveratrol (Leiro et al., 2004; Walle et al., 2004).

Estudos referentes ao metabolismo e aos efeitos biológicos exercidos pelo isômero trans-resveratrol denotam um elevado potencial antioxidante proporcionado pela sua capacidade de absorver os radicais livres presentes no meio (Goldberg et al., 1995b).

A descoberta de novos compostos capazes de proteger as células absorvendo os radicais livres é de grande interesse em diversas áreas da saúde, como a biologia celular, a medicina nuclear e a medicina preventiva, dado que os radicais livres são considerados produtos tóxicos formados tanto por processos fisiológicos decorrentes do envelhecimento celular como pela incidência da radiação ionizante no organismo.

Os efeitos protetores exercidos pelo resveratrol durante o processo de desenvolvimento de determinados danos oxidativos promovem a diminuição da incidência de doenças cardiovasculares (Goldberg et al., 1995a), indução da resposta antiinflamatória (Leonard et al., 2003), prevenção ou inibição de doenças degenerativas (Vingtdeux et al., 2008), prevenção no desenvolvimento de diversos tipos de câncer (Pervaiz, 2004).

Estudos sobre a ação do resveratrol no ciclo celular de diversas linhagens normais e tumorais comprovaram uma tendência das células em permanecerem na fase de síntese (fase S) quando na presença do composto. A fase $S$ do ciclo celular apresenta uma elevada resistência aos efeitos deletérios provindos da incidência da radiação ionizante (Mettler Junior e Upton, 1995; Sgambato et al., 2001).

A radiação gama, radiação ionizante do tipo eletromagnética com elevada energia de penetração, interage com o organismo vivo por reações direta e indireta (Dowd e Tilson, 1999).

A interação direta consiste na incidência da radiação ionizante diretamente em macromoléculas biológicas como o ácido desoxirribonucléico (DNA) e o ácido ribonucléico (RNA). Por sua vez, a interação indireta induz a 
formação dos radicais livres durante a incidência da radiação com as diversas moléculas presentes na interior das células. Dentre elas, a água é considerada a substância com maior probabilidade de interagir com a radiação ionizante, por representar 70 a 85\% do conteúdo celular (Dowd e Tilson, 1999; Mettler Junior e Upton, 1995).

A interação da radiação com as moléculas da água produz os "produtos primários da radiólise da água", cujos componentes são extremamente reativos e capazes de desencadear inúmeras reações tóxicas no interior das células (Getoff, 1996):

$$
\mathrm{H}_{2} \mathrm{O}+\text { radiação }=\mathrm{OH}^{\cdot}+\mathrm{H}^{+}+\mathrm{H}_{2}+\text { é}_{\mathrm{aq}}+\mathrm{H}_{2} \mathrm{O}_{2}+\mathrm{H}_{3} \mathrm{O}^{+}
$$

Desde os primeiros estudos referentes aos efeitos benéficos do resveratrol à saúde, constantes esforços têm sido despendidos na tentativa de desvendar as propriedades biológicas do composto em processos fisiológicos e patológicos para avaliar o seu potencial clínico.

As propriedades inerentes ao resveratrol como a baixa atividade tóxica intrínseca (Sgambato et al., 2001), potente atividade antioxidante (Leonard et al., 2003), relativa estabilidade molecular (Trela e Waterhouse, 1996) e a capacidade de inibir o crescimento de diversas linhagens celulares tumorais (Pervaiz, 2004; Whyte et al., 2007) tornam relevante e de grande contribuição científica o estudo do seu efeito radioprotetor.

O estudo in vitro do efeito radioprotetor do resveratrol é inédito na literatura, na qual consta apenas uma recente publicação (Carsten et al., 2008) referente a atividade radioprotetora in vivo do resveratrol. 


\section{2- OBJETIVO}

Este trabalho visou a determinação in vitro do efeito radioprotetor do resveratrol em cultura celular de tecido conectivo de camundongo exposta à radiação gama proveniente de uma fonte de Cobalto-60.

Para atingir o objetivo, foram realizados os seguintes testes:

- Teste in vitro de citotoxicidade do resveratrol;

- Teste in vitro da dose letal $50 \%$ da radiação gama em cultura celular;

- Avaliação in vitro das concentrações não tóxicas do resveratrol frente às diferentes doses de radiação gama para a determinação do efeito radioprotetor do resveratrol. 


\section{3 - REVISÃO DA LITERATURA}

\section{1- Histórico}

A uva é uma das frutas mais antigas e mais difundidas no mundo. Estudos arqueológicos e paleobotânicos estimam que as práticas do cultivo da videira e da produção de vinho remontam da época pré-romana sendo procedentes das regiões meridionais do extremo ocidente peninsular; regiões estas, caracterizadas por possuírem acentuadas tradições de contato e intercâmbios com o mundo mediterrâneo (Fabião, 1998).

O primeiro registro escrito referente ao uso medicinal do vinho provém do Antigo Egito, na cidade de Nippur, sendo procedente de anos anteriores a 2000 a.C. Nele há referências que na Suméria, unguentos eram misturados ao vinho para combater as doenças de pele. Outros registros datados de anos posteriores relatam o uso do vinho no tratamento primário das doenças agudas e crônicas existentes na época (Pickeleman, 1990).

Na Grécia Antiga, Homero descreveu na llíada e na Odisséia (850 a.C. apud Pickeleman, 1990) o valor do uso local e sistêmico do vinho no tratamento dos ferimentos de guerra, e Hipócrates (460-370 a.C. apud Béliveau e Gingras, 2007; Pickeleman, 1990) relatou em sua "História da Medicina" as propriedades terapêuticas da bebida quando administrada em dosagens adequadas.

Na Idade Média (século $\mathrm{V}$ ao século XV), as supostas propriedades curativas, energizante, rejuvenescedora, estimulante do apetite e promovedora da higienização dos dentes, tornaram os vinhos aromatizados com ervas parte integrantes da prática médica (Béliveau e Gingras, 2007; Pickeleman, 1990).

Do século XVII ao XIX o vinho foi universalmente descrito como agente promotor de bem estar físico e emocional, tendo intensificada a sua prática na medicina européia (Béliveau e Gingras, 2007; Pickeleman, 1990).

A partir do século $X X$, os indícios sobre os efeitos benéficos do vinho à saúde foram comprovados por estudos epidemiológicos, os quais constataram uma correlação inversa entre o consumo moderado de vinho e a incidência de 
doenças cardiovasculares, fenômeno este denominado "Paradoxo Francês" (Béliveau e Gingras, 2007; Sun et al., 2002).

Os franceses possuem hábitos considerados fatores de alto risco para o desenvolvimento de cardiopatias, como o consumo exacerbado de gordura animal, tabagismo em demasia e sedentarismo, porém exibem uma baixa incidência de distúrbios cardiovasculares devido ao consumo regular e moderado de vinho tinto durante as refeições (Béliveau e Gingras, 2007; Sun et al., 2002).

Segundo a Organização Mundial de Saúde (WHO, 2004), nos anos de 1961 a 2000, o consumo mundial de vinho permaneceu constante em decorrência do equilíbrio entre a leve redução do consumo por países tradicionalmente apreciadores da bebida e o discreto aumento em outras culturas, tendo-se estimado um consumo mundial médio de 1,3 litros de vinho por adulto ao ano. Em recente publicação (WHO, 2009), a OMS enfatiza os efeitos benéficos à saúde exercidos pelo etanol, presente em bebidas alcoólicas, quando consumido moderadamente.

No vinho, o efeito cardioprotetor também está associado à presença de compostos pertencentes à classe dos polifenóis (Goldberg et al., 1995a; WHO, 2009). Dentre os polifenóis contidos no vinho, o resveratrol $(3,4,5$ trihidroxiestilbeno) é considerado o composto fenólico de maior eficácia biológica (Frémont, 2000; Soleas et al., 1997).

Devido às perspectivas de amplos benefícios à saúde, nos últimos anos o resveratrol tornou-se alvo de intensos estudos.

\section{2- Biossíntese do resveratrol}

O resveratrol (3,4',5-trihidroxiestilbeno) é uma fitoalexina pertencente à restrita família estilbeno (Jeandet et al., 2002). Fitoalexinas são compostos antimicrobianos de baixo peso molecular, cuja síntese é naturalmente desencadeada por diversas espécies de plantas em situações de estresse, sendo um mecanismo de auto defesa contra diversos predadores, patógenos, agentes químico e físico (VanEtten et al., 1994).

A biossíntese do resveratrol (FIG.1) é desencadeada por um sinal químico, gerado pelo estresse, que induz o aumento da expressão do gene estibeno sintetase, o qual promove o acúmulo de mRNA estilbeno sintetase, responsável pela formação da enzima estilbeno sintetase. Por sua vez, esta 
enzima catalisa a reação entre uma molécula de $p$-coumaroyl-CoA e três moléculas de malonyl-CoA, substratos estes presentes nas plantas, originando o resveratrol na área afetada (Jeandet et al., 2002; Schröder et al., 1988; Schöppner e Kindl, 1984).

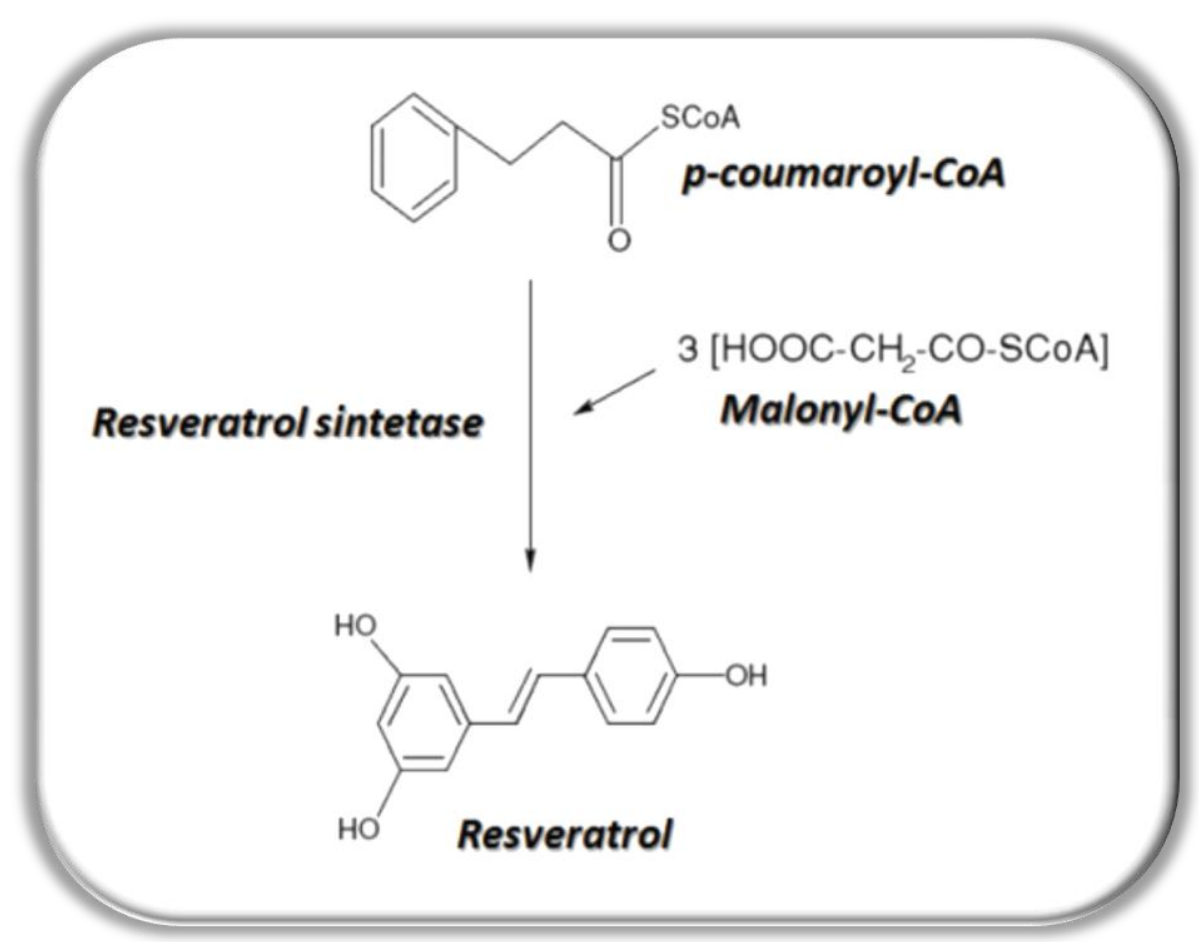

FIGURA 1 - Representação esquemática do processo de biossíntese do resveratrol

Em condições fisiológicas, a enzima estilbeno sintetase está presente em baixas concentrações na parede celular das plantas e em menor proporção, nos cloroplastos situados na película do fruto em desenvolvimento. Um acúmulo progressivo da enzima na película do fruto é observado ao longo do seu desenvolvimento (Pan et al., 2009).

$\mathrm{Na}$ uva, o resveratrol é sintetizado na película do fruto em concentrações que dependem tanto do tipo, intensidade e durabilidade do estresse sob o qual se encontra a videira durante a fase frutífera, como do estágio de desenvolvimento do fruto (Pan et al., 2009). O estresse pode ser ocasionado por fatores bióticos como ferimentos na uva decorrentes da ação fúngica, principalmente pela espécie Botrytis cinéria, e por fatores abióticos, como 
exposição à radiação ultravioleta emitida pelo sol (Adrian et al., 2000; DouilletBreuil et al., 1999) e agentes químicos (Adrian et al., 1996). Logo, são de extrema relevância para a obtenção de elevadas concentrações de resveratrol, as condições da viticultura, a origem geográfica, os fatores ambientais no vinhedo e as variedades da uva (Goldberg et al., 1995b).

\section{3- Estrutura química do resveratrol}

O resveratrol é constituído por dois anéis aromáticos unidos por uma ponte de metileno $\left(-\mathrm{CH}_{2}-\right.$ ) (Soleas et al., 1997). Na natureza, esta geometria molecular é a base estrutural de diferentes compostos, sendo diferenciados quanto ao número e a posição das hidroxilas; substituição dessas hidroxilas por diferentes radicais como os açúcares $\left[\left(\mathrm{CH}_{2} \mathrm{O}\right)_{n}\right]$, metil $\left(-\mathrm{CH}_{3}\right)$, grupo metoxila $\left(\mathrm{CH}_{3} \mathrm{O}-\right)$; formação de dímeros, trímeros ou extensos polímeros e o isomerismo (isômeros geométricos trans e cis) (Soleas et al., 1997).

Atualmente, consta na literatura uma ampla descrição desses compostos, sendo enfatizadas as formas isômeras trans- e cis- resveratrol $\left(3,4^{\prime}, 5\right.$ trihidroxi-trans-estilbeno e 3,4',5-trihidroxi-cis-estilbeno); trans- e cis-piceido (trans-resveratrol 3-O- $\beta$-glucosideo e cis-resveratrol 3-O- $\beta$-glucosideo) e viniferins (trans-viniferins).

As formas isômeras trans- e cis-resveratrol são relativamente estáveis. A conversão do isômero trans- em cis-resveratrol resulta da exposição à radiação UV, já o processo inverso ocorre em soluções de $\mathrm{pH}$ ácido $(\mathrm{pH}=1)$ (Trela e Waterhouse, 1996). Exposições à radiação UV e a soluções de pH elevado $(\mathrm{pH}=10)$ promovem a degradação dos dois isômeros, sendo a estabilidade alcançada quando mantidos em soluções de pH neutro, para cis-resveratrol, e em $\mathrm{pH}$ ácido, para trans-resveratrol, ambas sob o abrigo da luz (Trela e Waterhouse, 1996).

Como o isômero cis-resveratrol não é comercializado devido a sua instabilidade na forma sólida e o isômero trans-resveratrol é viabilizado comercialmente, através da conversão pela radiação UV do isômero transresveratrol, a forma cis é facilmente obtida (Goldberg et al., 1995b).

O piceido é oriundo do processo de glicosilação que acomete a molécula de resveratrol (Pezet et al., 2004). A glicosilação compreende na inclusão de uma molécula de glicose na estrutura química do resveratrol, 
tornando-a mais resistente aos processos de oxidação e degradação enzimática (Pezet et al., 2004).

Os compostos viniferins são formados pelo processo de dimerização oxidativa a partir da molécula de resveratrol (Jeandet et al., 2002; Pezet et al., 2004).

A FIG. 2 ilustra esquematicamente as formas estruturais do resveratrol e dos compostos análogos ao composto, cujas modificações químicas observadas são resultantes das reações de glicosilação e oxidação.

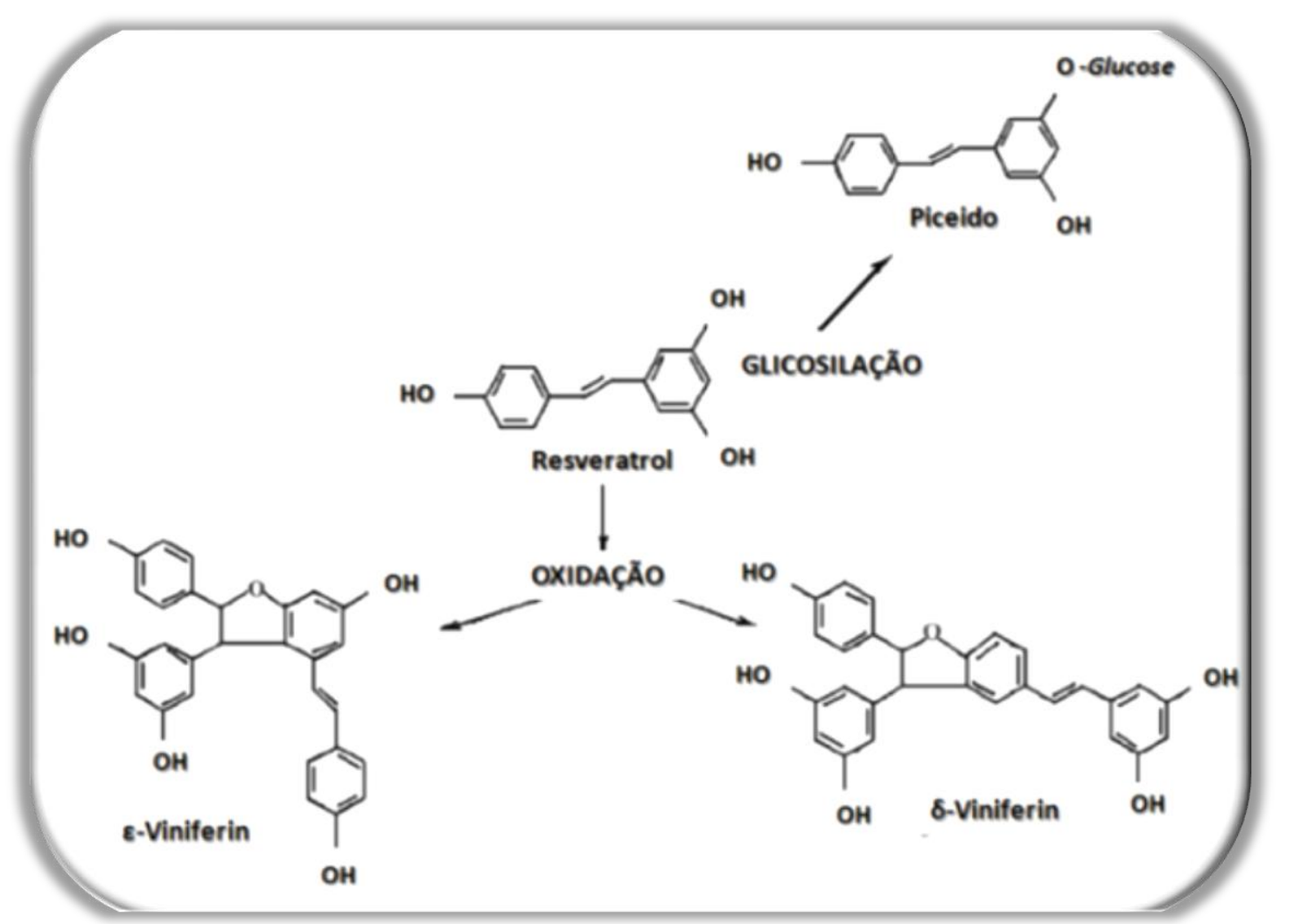

FIGURA 2 - Representação esquemática dos processos de síntese dos compostos derivados do resveratrol.

\section{4- Fontes de resveratrol}

Estudos pioneiros sobre o resveratrol abordaram mais intensamente as propriedades do isômero trans-resveratrol devido às dificuldades encontradas na detecção e quantificação do isômero cis-resveratrol e dos compostos de estruturas químicas derivadas do resveratrol (Frémont, 2000). Com o crescente 
desenvolvimento e adaptações das metodologias foi possível isolar e caracterizar esses compostos nas amostras de plantas (Careri et al., 2003), nos produtos alimentícios (Goldberg et al., 1994; Souto et al., 2001) e em materiais biológicos após a administração de alimentos e soluções com elevado teor de resveratrol (Walle et al., 2004).

Aproximadamente 72 espécies de plantas distribuídas em 31 gêneros e 12 famílias foram descritas como capazes de sintetizar naturalmente o resveratrol (Jang et al., 1997). Dentre essas plantas destacam-se, por seus reconhecidos efeitos terapêuticos, o amendoim (Arachis hypogacea, Fabaceae) (Chukwumah et al., 2009), o eucalipto (Eucalyptus wandoo, Myrtaceae) (Hathway e Seakins, 1959); Kon-jo-kon (Polygonum cuspidatum) (Du et al., 2007) e a uva (Vitis vinifera e Vitis labrusca,Vitaceae) (Douillet-Breuil et al., 1999; Frémont, 2000).

A FIG. 3 ilustra algumas espécies de plantas com reconhecida capacidade de sintetizar naturalmente o resveratrol. 


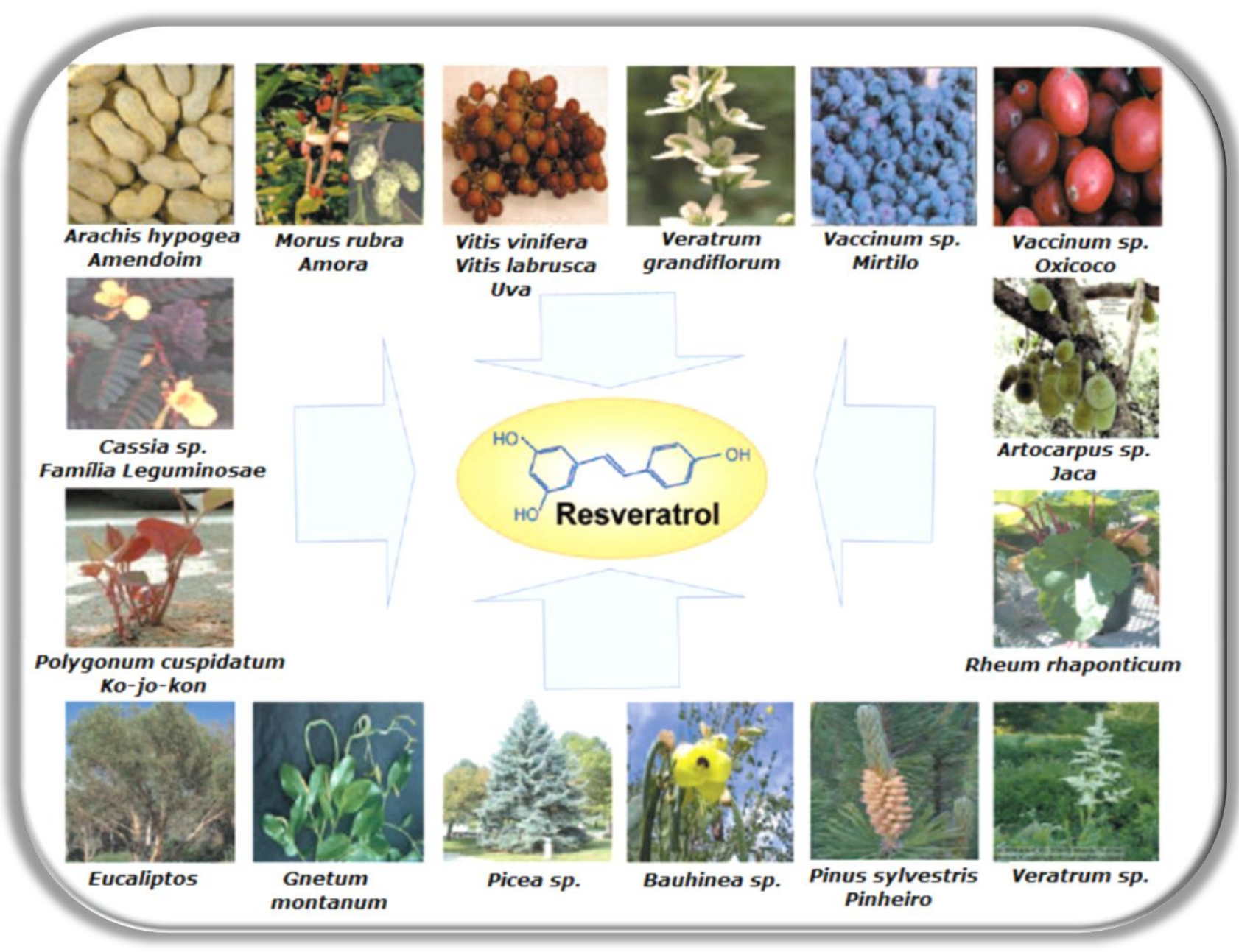

FIGURA 3 - Espécies de plantas com elevado potencial de síntese do resveratrol.

As espécies de videiras Vitis vinifera e Vitis labrusca possuem a maior capacidade de sintetizar o resveratrol (Frémont, 2000) destacando-se as variedades Pinot Noir, Merlot e Cabernet Sauvignon (Goldberg et al., 1995b; Romero-Pérez et al., 2001). Assim, as uvas e os seus produtos industrializados são considerados importantes fontes alimentícias do composto (Pan et al., 2009).

Nas análises realizadas em diferentes amostras de uva, o resveratrol apresentou maior concentração na película do fruto $(27,5 \mu \mathrm{g} / \mathrm{g})$, sendo que no bagaço da uva, constituído de caules, cascas e sementes após a extração do sumo, apresentou uma menor concentração $(6,0 \mu \mathrm{g} / \mathrm{g})$ (Careri et al., 2003). A análise da película do fruto detectou, em ordem decrescente de concentrações, os compostos: trans-resveratrol, trans- e cis- piceido, não sendo constatada a presença do isômero cis-resveratrol (Romero-Pérez et al., 2001). 
Nos vinhos, o resveratrol é encontrado em níveis relativamente elevados, principalmente nos vinhos tintos, cujos valores observados $(0,82$ a 5,75 $\mathrm{mg} / \mathrm{L}$ ) decorrem do longo processo de maceração na presença das cascas e sementes da uva (Souto et al., 2001). Nos vinhos brancos os níveis de resveratrol são inferiores a 1,8 mg/L devido a ausência do contato da casca da uva ao mosto (Frémont, 2000; Romero-Pérez et al., 1996). Já os vinhos rosés, por resultarem da mistura dos vinhos tintos e brancos ou serem produzidos com um tempo de maceração inferior ao dos vinhos tintos, possuem níveis de resveratrol intermediários, sendo de aproximadamente 2,15 mg/L (Frémont, 2000; RomeroPérez et al., 1996).

Assim como a prática enológica é importante para a obtenção do resveratrol, o processo de estocagem da bebida é um fator preponderante para a conservação dos elevados níveis do composto contido nos vinhos, pois o armazenamento da bebida em recipientes hermeticamente fechados e em locais escuros previnem a oxidação da molécula pela ação do oxigênio e a degradação pelos raios do sol, respectivamente (Douillet-Breuil et al., 1999; Celotti et al., 1996).

Nos vinhos de diferentes origens geográficas foram detectados: transe cis-resveratrol, trans- e cis-piceido; trans-astringina; $\epsilon$-viniferin e $\delta$-viniferin (Lima et al., 1999; Vitrac et al., 2005). A quantificação desses estilbenos nos diferentes vinhos evidenciou um equilíbrio entre as alterações das concentrações desses compostos, sugerindo que tanto o resveratrol como os seus derivados são sujeitos as mesmas variáveis (Goldberg et al., 1995b).

A FIG. 4 ilustra esquematicamente a estrutura química do resveratrol e dos seus derivados contidos nos vinhos. 
<smiles>Oc1ccc(/C=C/c2ccc(O)cc2)cc1</smiles>

Trans-resveratrol<smiles>Oc1ccc(/C=C\c2ccc(O)cc2)cc1</smiles>

Cis-resveratrol<smiles>O=[N+]([O-])Oc1cc(O)cc(/C=C\c2ccc(O)cc2)c1</smiles>

\section{Cis-resveratrol-3-O-glucoside (Cis-pideido)}

Trans-resveratrol-3-O-glucoside (Trans-pideido)<smiles></smiles>

Resveratrol trans-dehydrodimer (trans- $\delta$-viniferin)<smiles>CC(C)C=Cc1cccc2c1C(c1cc(O)cc(O)c1)C(c1ccc(O)cc1)C2</smiles>

Trans- $\varepsilon$ - viniferin<smiles>COc1cc(O)cc(/C=C/c2ccc(O)c(O)c2)c1</smiles>

Trans-astringina

FIGURA 4 - Fórmulas estruturais do resveratrol e dos estilbenos análogos presentes nos vinhos

Os demais produtos industrializados derivados da uva como os sucos, geléias e as gelatinas apresentaram concentrações de resveratrol inferiores a $0,15 \mathrm{mg} / \mathrm{L}$ (Goldberg et al., 1994).

Os sucos de uva de origem brasileira são considerados uma boa fonte do composto para os abstêmios, pois apresentaram concentrações relativamente elevadas (0,19 a 0,90 mg/L) (Sautter et al., 2005).

\section{5- Processos de absorção e distribuição do resveratrol pelo organismo vivo}

Com a presença do resveratrol e de seus derivados em uma ampla variedade de alimentos e bebidas, considerável atenção tem sido dispensada ao 
percurso desses compostos nos organismos vivos, enfatizando-se os seus mecanismos de ação.

Um recente estudo em seres humanos, submetidos à administração oral e intravenosa de resveratrol, constatou que aproximadamente $70 \%$ do composto são absorvidos pelo organismo. Dessa porcentagem, uma ínfima parte permanece na circulação sistêmica em sua forma inalterada, sendo predominante a presença dos metabólitos formados pelos processos de sulfatação e glicosilação (Walle et al., 2004).

O processo de sulfatação consiste numa rápida reação entre 0 resveratrol e o sulfato originando o metabólito trans-resveratrol-3-sulfato; enquanto a glicosilação ocorre em menor intensidade e é responsável pela formação do metabólito trans-resveratrol-3-O-glucoronide através da reação do resveratrol com o ácido glicurônico (Walle et al., 2004; Yu et al., 2002).

O processo de distribuição do resveratrol pelos tecidos é realizado pela difusão trans-epitelial (transporte passivo) e pelo processo mediado por uma proteína carreadora (Jannin et al., 2004; Walle et al., 2004). Ambos os processos são facilitados pela característica lipossolúvel do composto e pela elevada afinidade à proteína albumina (Jannin et al., 2004).

A excreção do resveratrol e de seus metabólitos é eficazmente exercida com o auxílio dos líquidos biológicos como a bile e a urina (Vitrac et al., 2003; Wang et al., 2008).

Em cobaias, constatou-se que após a administração oral ou intravenosa, o resveratrol tende a ser rapidamente eliminado da circulação sanguínea (Chen et al., 2007) se depositando em diferentes órgãos, tais como: estômago, intestino delgado - duodeno, intestino grosso - cólon, fígado, baço, rim, coração, pulmão, cérebro e testículo, cuja ordem citada obedece aos níveis decrescentes das concentrações detectadas (Vitrac et al., 2003; Wang et al., 2008). No cólon e no baço, observou-se uma significativa atividade do resveratrol, enquanto que no coração, testículos e no cérebro essa atividade foi considerada moderada (Vitrac et al., 2003).

Apesar dos constantes esforços despendidos na tentativa de obter conhecimentos in vivo sobre a absorção, metabolismo e distribuição do resveratrol nos diversos tecidos, os estudos encontram dificuldades na detecção e quantificação do composto devido à sua rápida absorção pelo intestino, limitada 
estabilidade dos metabólitos, ampla distribuição pelos órgãos após a ingestão e rápida eliminação (Leonard et al., 2003). Assim, para que as conclusões sobre o impacto na saúde humana proporcionado pelas dietas com elevado teor de resveratrol sejam obtidas, é necessário desenvolver estudos mais minuciosos e aprofundados (Frémont, 2000).

Atualmente, há fortes evidências que o resveratrol acumulado nas células epiteliais ao longo do trato gastrintestinal, juntamente com os metabólitos formados, promove benefícios à saúde (Walle et al., 2004). Similarmente, o isômero cis possui atividades biológicas complementares ao do isômero trans, embora sejam consideradas de menor intensidade (Leiro et al., 2004).

\section{6- Efeitos biológicos exercidos pelo resveratrol}

A intensidade dos efeitos biológicos proporcionados pelo resveratrol está intimamente relacionada à conformação estrutural do composto sendo a disposição do grupo fenol, apresentada pela molécula do isômero transresveratrol, o fator essencial para o desenvolvimento da sua atividade antioxidante (Leonard et al., 2003).

A atividade antioxidante decorre da capacidade do composto em se ligar aos radicais livres presentes no meio celular.

Os radicais livres são produtos resultantes do metabolismo celular, considerados como iniciadores de processos oxidativos devido a sua capacidade de desencadear reações envolvidas em distintos processos patológicos em decorrência do seu aumento e/ou diminuição de antioxidantes (Leonard et al., 2003). Assim, a capacidade antioxidante do resveratrol é um importante mecanismo de prevenção ou inibição de determinados estresse oxidativos que acometem diversas linhagens celulares (Sgambato et al., 2001).

Dentre os efeitos proporcionados pela atividade antioxidante do resveratrol, a cardioproteção foi amplamente estudada por resultar de uma variedade de efeitos antioxidantes exercidos pelo composto, tais como a prevenção da oxidação de lipoproteínas de baixa densidade (LDL) (Leonard et al., 2003), inibição da agregação plaquetária (Olas et al., 2002), atividades de vaso relaxamento e vaso dilatação (Naderali, 2009), proteção do endotélio vascular contra disfunções e malefícios decorrentes de dietas inadequadas (Chaves et al., 
2009), atividade estrogênica (Gehm et al., 1997) e redução da obesidade (Naderali, 2009).

Extensos estudos sobre a atuação do resveratrol no combate ao HIV-1 (Heredia et al., 2000), inibição das lesões induzidas pelo Herpes dos tipos 1 e 2 (Docherty et al., 1999; Docherty et al., 2004), inibição do crescimento de Helicobacter pylori (Mahady et al., 2003) e controle dos processos inflamatórios (Olas et al., 2002; Leonard et al., 2003) constam na literatura.

Atualmente, um dos campos de pesquisa de notável interesse científico é o aumento da longevidade com melhora na qualidade de vida. A capacidade do resveratrol em diminuir a incidência ou amenizar os danos decorrentes das doenças degenerativas resultantes do envelhecimento celular e orgânico, tais como a doença de Alzheimer (Vingtdeux et al., 2008) e as isquemias cerebrais (Choi et al., 2007) são extensamente abordadas pela literatura.

O resveratrol também apresenta capacidade de suprimir, in vitro e in vivo, a proliferação de linhagens tumorais de diversos órgãos como o crânio (Miloso et al., 1999), mama (El-Mowafy e Alkhalaf, 2003), pulmão (Whyte et al., 2007), estômago (Atten et al., 2001), fígado (Bishayee e Dhir, 2009), pâncreas (Golkar et al., 2007), próstata (Lin et al., 2002), ovário (Opipari Junior et al., 2004), cólon (Sgambato et al., 2001), pele (Asensi et al., 2002), incluindo as leucemias e os linfomas (Wieder et al., 2001).

Dentre os complexos mecanismos de inibição do crescimento tumoral promovidos pelo resveratrol, são destacados: ativação da apoptose (Wieder et al., 2001), atividade antioxidante (Leonard et al., 2003), sincronização das células em determinada fase do ciclo celular (Sgambato et al., 2001) e alteração das principais etapas da carcinogênese (Pervaiz, 2004).

O ciclo celular de uma célula em proliferação é caracterizado pelos períodos de replicação e divisão do DNA, sendo representado por um círculo subdividido em quatro fases: $M, G_{1}, S$ e $G_{2}$. A fase $M$ representa a etapa de mitose celular, $\mathrm{G}_{1}$ indica o período entre o término da divisão e o início da síntese de DNA, a fase $S$ refere-se à síntese de DNA, e $G_{2}$ inicia-se com a síntese de proteínas e RNA necessários para a divisão que ocorrerá na fase de mitose. Um período $G_{0}$ pode ser incluído entre as fases $M / G_{1}$ para representar o estado quiescente da célula (Metter e Upton, 1995). 
Estudos sobre o ciclo celular de linhagens normais e tumorais constataram que o resveratrol tende a alterar a distribuição das células nas fases, observando-se geralmente uma predominância da fase $S$ associada a uma diminuição das fases $G_{2} / M$ e em menor frequência, das fases $G_{0} / G_{1}$ (Sgambato et al., 2001).

A carcinogênese é um processo de múltiplas etapas que envolvem primeiramente a mutação (Iniciação), seguida pelo desenvolvimento dessa mutação na célula e seqüencialmente em uma sub-população, estabelecendo-se o fenótipo neoplásico (Diferenciação/Promoção) e por fim, o crescimento tumoral (Progressão) (Pervaiz, 2004). A busca por agentes químicos capazes de interromper essas complexas etapas, impedindo a aquisição do fenótipo anormal, evidenciou alguns dos inúmeros mecanismos de ação do resveratrol atuantes na prevenção e no controle das neoplasias já instaladas.

\section{7- Radiação ionizante}

A radiação ionizante é definida como a energia propagada capaz de deslocar um ou mais elétrons da molécula (Fajardo et al., 2001). Nos organismos vivos, a incidência dessa radiação promove danos às células por mecanismos específicos, como as interações por ação direta e indireta da radiação com o meio celular (Dowd e Tilson, 1999).

A interação direta consiste na incidência da radiação ionizante diretamente nas macromoléculas biológicas como o ácido desoxirribonucléico (DNA) e o ácido ribonucléico (RNA). Essa interação promove danos que podem ser fatais à célula. As lesões no DNA que não induzem a morte celular, devido aos mecanismos fisiológicos de reparação celular, podem ser transmitidas para as gerações de células futuras, iniciando-se o processo de neoplasia celular (Dowd e Tilson, 1999).

$\mathrm{Na}$ ação indireta ocorrem sucessivas interações da radiação incidente com as diversas moléculas presentes no interior celular, destacando-se a água e o oxigênio (Dowd e Tilson, 1999). Essa interação é mais freqüente que a interação direta, devido à abundância de água presente no meio celular (Mettler Junior e Upton, 1995).

A primeira etapa da ação indireta da radiação gama é o processo da radiólise da água. Neste processo, são gerados espécies reativas primárias $\left(\mathrm{OH}^{*}\right.$, 
éaq, $\left.\mathrm{H}^{+}\right)$e produtos moleculares $\left(\mathrm{H}_{2}, \mathrm{H}_{2} \mathrm{O}_{2}\right)$, denominados "produtos primários da radiólise da água". Altamente reativos, os produtos primários interagem com as moléculas presentes no meio ou sofrem recombinações, desencadeando uma série de reações tóxicas para as células que promovem alterações químicas e biológicas (Fajardo et al., 2001; Getoff, 1996).

A radiólise da água é um processo contínuo que pode ser representado pela equação:

$$
\mathrm{H}_{2} \mathrm{O}+\text { radiação }=3,2 \mathrm{OH}^{\bullet}+0,6 \mathrm{H}^{+}+0,7 \mathrm{H}_{2} \mathrm{O}_{2}+2,7 \text { é}_{\mathrm{aq}}+0,45 \mathrm{H}_{2}+0,45 \mathrm{H}_{3} \mathrm{O}^{+}
$$

A radiação gama, radiação ionizante do tipo eletromagnética com elevada energia de penetração, interage mais frequentemente com os organismos vivos pela ação indireta (Mettler Junior e Upton).

Em diversos experimentos realizados com células em cultura evidenciaram que a sensibilidade à radiação ionizante depende da fase do ciclo celular em que as células se encontram quando irradiadas (Mettler Junior e Upton, 1995). Em geral, a maioria das células pluricelulares é considerada mais sensível durante a fase de mitose, devido à descondensação cromossômica, e mais resistente no período tardio da fase de síntese (Mettler Junior e Upton, 1995). Logo, uma mesma linhagem celular pode apresentar diferenças quanto à sensibilidade à radiação devido à distribuição das células nas diferentes fases do ciclo celular (Mettler Junior e Upton, 1995).

\section{8- Efeito radioprotetor}

Em 2008, Carsten et al. publicaram um estudo inédito sobre o efeito radioprotetor do resveratrol in vivo. Esse trabalho foi realizado em camundongos distribuídos em quatro grupos para estudo: Grupo 1) camundongos que não receberam o resveratrol; Grupo 2) camundongos tratados com o resveratrol (100 $\mathrm{mg} / \mathrm{Kg} / \mathrm{dia}$ ); Grupo 3) camundongos submetidos a radiação gama em dose única de 3 Gy; Grupo 4) camundongos tratados previamente com o resveratrol (100 $\mathrm{mg} / \mathrm{Kg} / \mathrm{dia}$ ) e posteriormente, submetidos à dose única de radiação gama (3 Gy). A avaliação dos danos proporcionados pela radiação foi realizada pela análise das células da medula óssea dos animais. Nela, constatou-se uma significativa redução na incidência de aberrações cromossômicas nos grupos de animais 
tratados com o resveratrol quando comparados ao grupo que somente foi submetido à radiação, sem o prévio tratamento.

Os compostos com potencial radioprotetor possuem elevada capacidade de prevenir os diferentes danos ocasionados pela interação dos radicais livres com os constituintes das células. Para se obter a eficácia da radioproteção, é necessário que os agentes radioprotetores estejam presentes no interior das células no momento ou logo após a irradiação, pois o mecanismo de ação desses compostos é a captura dos radicais livres presentes no meio celular (Fajardo et al., 2001).

Como os compostos radioprotetores apresentam significativos efeitos colaterais, limitando ou impossibilitando a sua utilidade terapêutica (Fajardo et al., 2001; Mettler Junior e Upton, 1995), os estudos que visam à descoberta de compostos com potencial radioprotetor e baixa atividade tóxica intrínseca são de grande contribuição científica e clínica. 


\section{4- MATERIAIS E MÉTODOS}

Os ensaios biológicos foram realizados em cultura de células de tecido conectivo de camundongo, NCTC Clone 929, do American Type Culture Collection (ATCC CCL1) fornecida pela Seção de Culturas Celulares do Instituto Adolfo Lutz, SP.

O resveratrol (Resvetrol ${ }^{\circledR}$ ) foi adquirido da empresa Attivos Magistrais, Grupo Pharmacopéia, SP. Tal empresa atesta o produto, Resvetrol ${ }^{\circledR}$, como sendo a forma trans pura padronizada, $100 \%$ ativa.

O meio de cultura, meio mínimo de Eagle (MEM), foi fornecido pela Seção de Culturas Celulares do Instituto Adolfo Lutz, SP. Todos os reagentes químicos utilizados foram de grau PA e adquiridos da Merck ou da Carlo Erba.

A radiação gama foi proveniente de uma fonte de Cobalto-60, GammaCell 200 (Atomic Energy of Canada Limited - Ottawa, Canadá), localizado no Centro de Tecnologia das Radiações (CTR) do Instituto de Pesquisas Energéticas e Nucleares / Comissão Nacional de Energia Nuclear (IPEN/CNEN), SP.

A balança analítica (BP121S, Sartorius), a estufa incubadora de $\mathrm{CO}_{2}$ (CB150, Binder), o fluxo laminar (classe 100, Filtracom), o freezer (Compacto 100, Cônsul), o espectrofotômetro para ensaios imunoenzimáticos (RC Sunrise, Tecan), as vidrarias e os instrumentos de laboratório foram utilizados no Centro de Química e Meio Ambiente (CQMA) - IPEN/CNEN, SP.

\section{1- Preparo da cultura celular nas microplacas}

O processo de preparo da cultura celular nas microplacas foi realizado pela Seção de Culturas Celulares do Instituto Adolfo Lutz como descrito a seguir.

As células da linhagem NCTC Clone 929 foram cultivadas em garrafa de cultura celular utilizando-se MEM suplementado com $10 \%$ de soro fetal bovino (SFB), 0,1 mM de aminoácidos não essenciais e 1,0 mM de piruvato de sódio e permaneceram em estufa a $37^{\circ} \mathrm{C}$ até a formação da monocamada celular. Não foram adicionados antibióticos ao meio de cultura celular. 
Em prosseguimento, a cultura celular foi tratada com tripsina $0,20 \% \mathrm{e}$ solução de EDTA 0,02\% para a dispersão da monocamada celular.

Após o destaque das células, com o auxílio do hemocitômero (câmara de contagem de Neubauer), as células foram contadas e a suspensão celular, acertada em concentrações adequadas para cada ensaio a ser realizado. Um volume de $0,2 \mathrm{~mL}$ da suspensão celular obtida foi distribuído em cada orifício da microplaca de cultura celular de 96 poços de fundo chato.

A seguir, as microplacas foram incubadas por 24 horas em estufa a $37^{\circ} \mathrm{C}$ e atmosfera úmida com $5 \%$ de $\mathrm{CO}_{2}$ para a formação e a adesão da monocamada celular nos poços (FIG. 5).

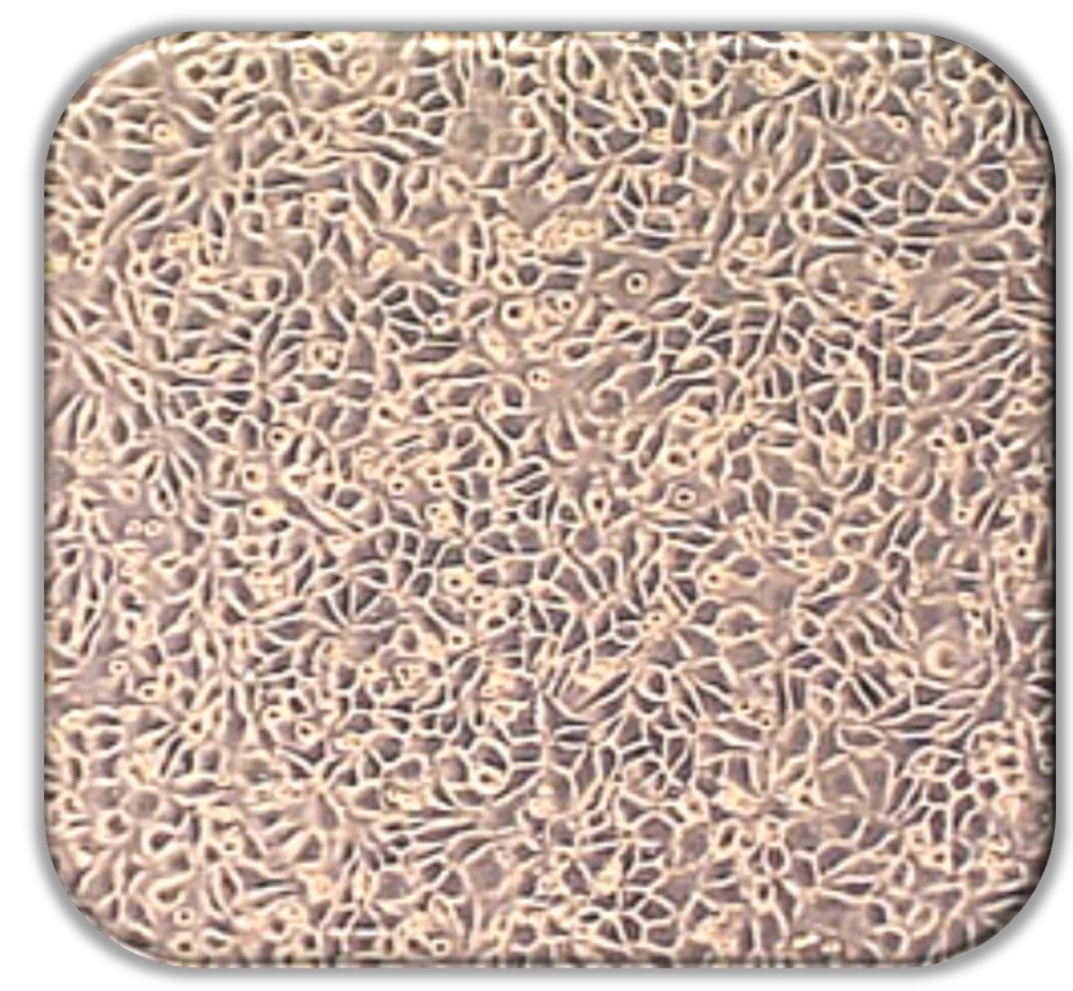

FIGURA 5 - Monocamada de células da linhagem NCTC Clone 929, aumento 100 x. Fonte: http://www.devicelink.com/mddi/index.html

A FIG. 6 ilustra uma microplaca de cultura celular de 96 poços contendo a suspensão celular no interior dos orifícios. 


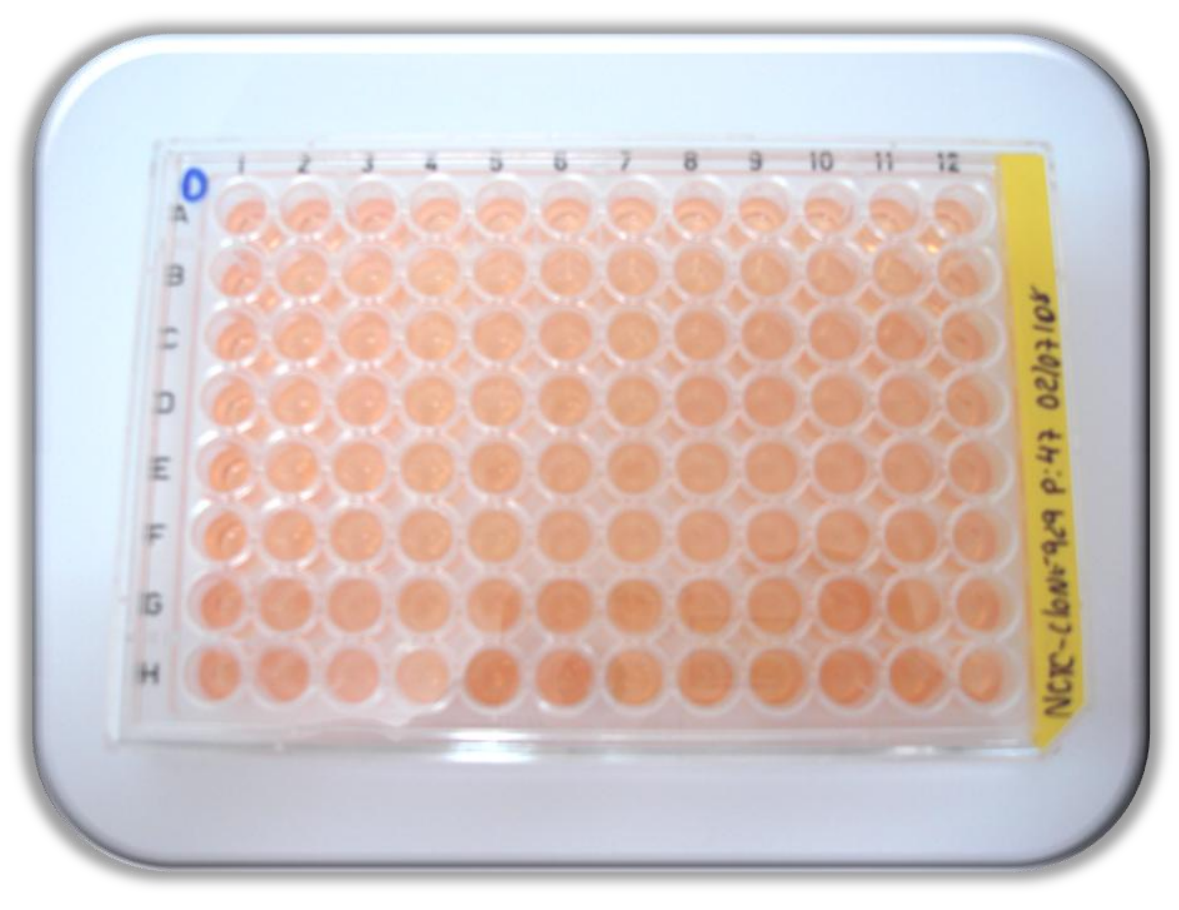

FIGURA 6 - Microplaca de cultura celular

\section{2- Determinação in vitro do índice de citotoxicidade $\left(\mathrm{IC}_{50 \%}\right)$ do resveratrol}

Para verificar o nível de toxicidade do resveratrol, foi realizado in vitro o teste de citotoxicidade pelo método de incorporação do corante vermelho neutro em conformidade com as normas internacionais (ISO 10993-5, 1999) e a metodologia descrita na literatura (Rogero et al., 2003).

Este estudo foi realizado na linhagem celular NCTC Clone 929 do ATCC distribuída em microplacas de 96 poços a uma densidade de $7,0 \times 10^{4}$ células/poço, cujo preparo decorreu como descrito no item 4.1.

Inicialmente, uma solução alcoólica de resveratrol na concentração de $1,0 \times 10^{4} \mu \mathrm{M} / \mathrm{L}$ foi preparada. A partir dessa solução, foram realizadas cinco diluições seriadas em MEM com 5\% de SFB, obtendo-se as concentrações de: 250, 125, 62,5, 31,25 e 15,63 $\mu \mathrm{M} / \mathrm{L}$ (FIG. 7). Estas soluções foram submetidas a um processo de esterilização, passando-as por um sistema de membranas contendo poros de 0,22 $\mu \mathrm{m}$ de diâmetro (FIG. 8). 


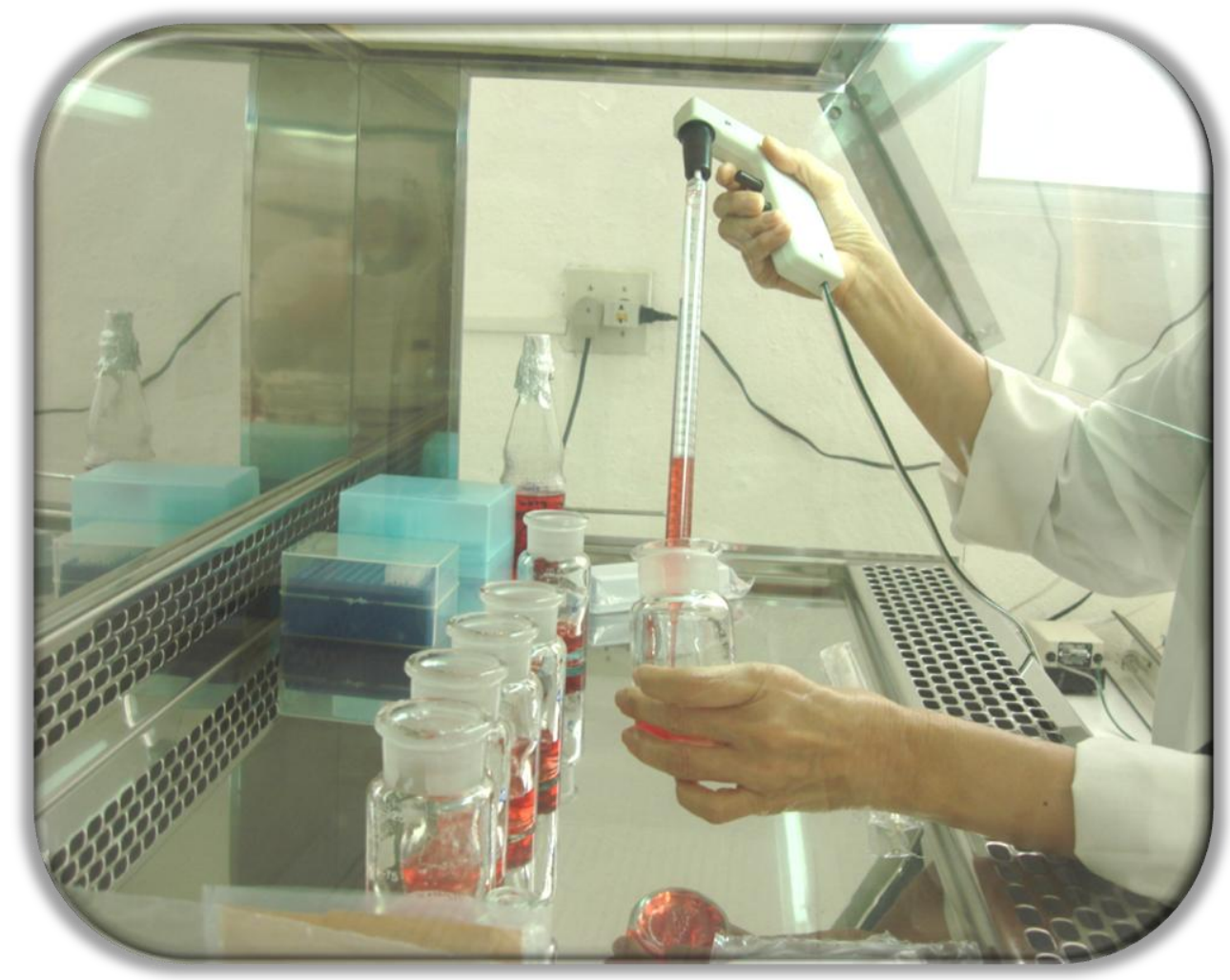

FIGURA 7 - Diluições em série efetuadas no fluxo laminar para a obtenção das soluções de diferentes concentrações de resveratrol

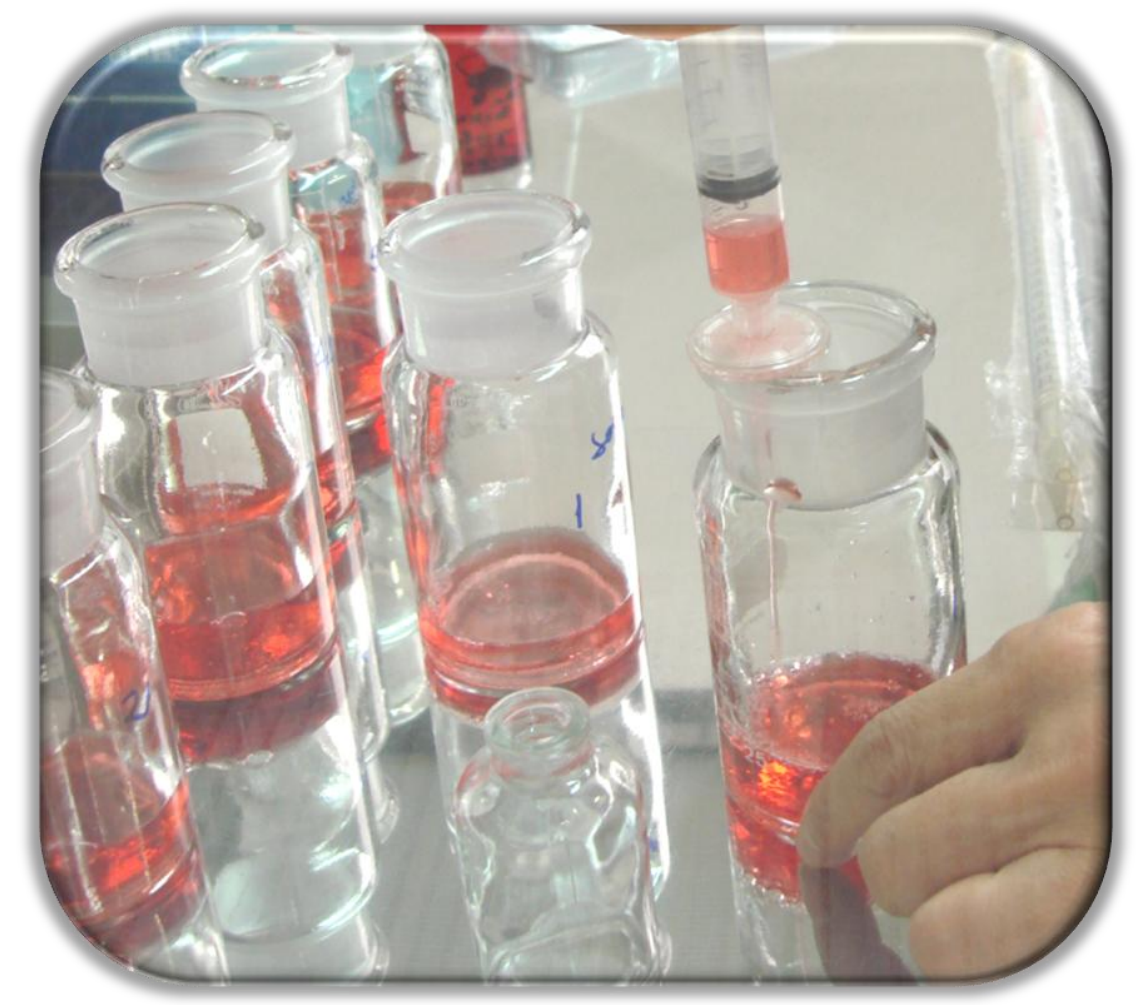

FIGURA 8 - Processo de esterilização das soluções de resveratrol 
O extrato do controle negativo foi preparado pela imersão de policloreto de vinila (PVC atóxico) em MEM, na proporção de $1 \mathrm{~cm}^{2}$ de área superficial por $\mathrm{mL}$ de meio de cultura, permanecendo em estufa durante 24 horas a $37^{\circ} \mathrm{C}$.

Os controles positivo (solução de fenol $0,02 \%$ ) e negativo (extrato de vinila - PVC atóxico) foram submetidos ao mesmo procedimento de diluição seriada realizado com o resveratrol, sendo avaliados nas concentrações de: 100, $50,25,12,5$ e $6,25 \%$.

A FIG.9 ilustra os controles positivo e negativo utilizados no ensaio in vitro de citotoxicidade do resveratrol.

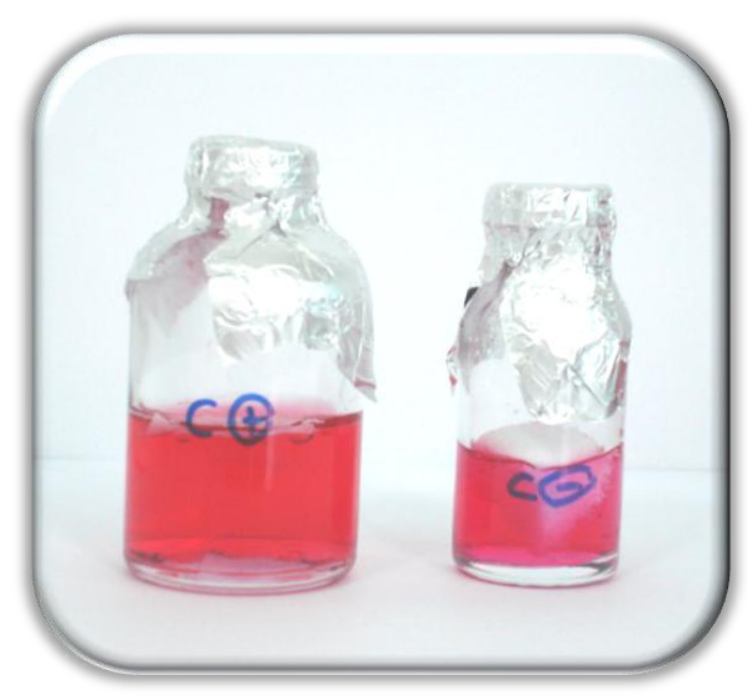

FIGURA 9 - Controle positivo (solução de fenol 0,02\%) e controle negativo (extrato de PVC atóxico) utilizados no ensaio in vitro de citotoxicidade do resveratrol

Após o descarte do meio de cultura contido na microplaca, um volume de $0,2 \mathrm{~mL}$ de cada solução da amostra e dos controles foi depositado nos poços contendo a cultura celular. Como controle de células, foi adicionado em triplicata um volume de $0,2 \mathrm{~mL}$ de MEM com $5 \%$ de SFB.

A FIG. 10 ilustra esquematicamente a distribuição das soluções na microplaca. 


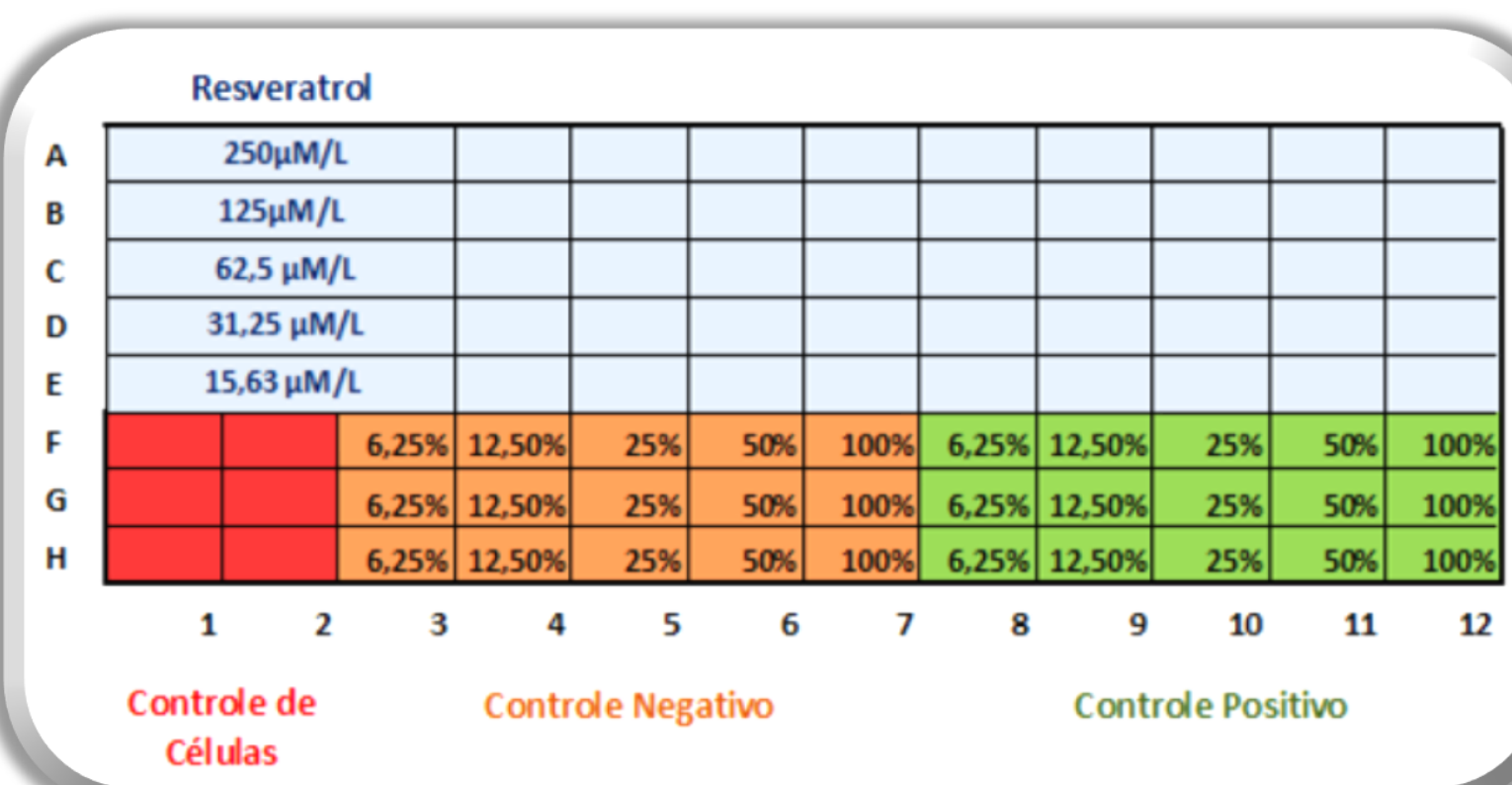

Figura 10 - Representação esquemática da distribuição das soluções de resveratrol, dos controles positivo e negativo e do MEM com 5\% de SFB, nos poços da microplaca de cultura celular para a realização do teste de citotoxicidade do resveratrol

Visando a verificação da reprodutibilidade deste teste biológico, foram realizados dois ensaios. No primeiro ensaio, a distribuição de cada diluição do resveratrol foi realizada em triplicata; já no segundo ensaio, cada solução de resveratrol foi depositada em doze poços.

Concluída a distribuição das soluções, a microplaca foi mantida por 24 horas em estufa a $37^{\circ} \mathrm{C}$ e atmosfera úmida com $5 \%$ de $\mathrm{CO}_{2}$.

Os procedimentos de preparo das soluções e de distribuição das mesmas na microplaca constituem a fase asséptica do ensaio. Para tal, os procedimentos foram realizados em laboratório esterilizado por luz UV e a manipulação da microplaca e do material estéril foi efetuado no fluxo laminar.

Decorrida às 24 horas de incubação, as soluções contidas na microplaca foram substituídas por $0,2 \mathrm{~mL}$ de solução de vermelho neutro em MEM $(50 \mu \mathrm{g} / \mathrm{mL})$ e a microplaca foi incubada por 3 horas. Esse período de incubação foi necessário para a incorporação do corante pelas células vivas.

Logo após, a microplaca foi lavada duas vezes com a solução salina tamponada com fosfato (PBS) e em seguida com $0,2 \mathrm{~mL}$ de solução aquosa de 
cloreto de cálcio $1 \%$ em formaldeído $0,5 \%$ (1:100) para remover o corante não incorporado pelas células (FIG. 11).

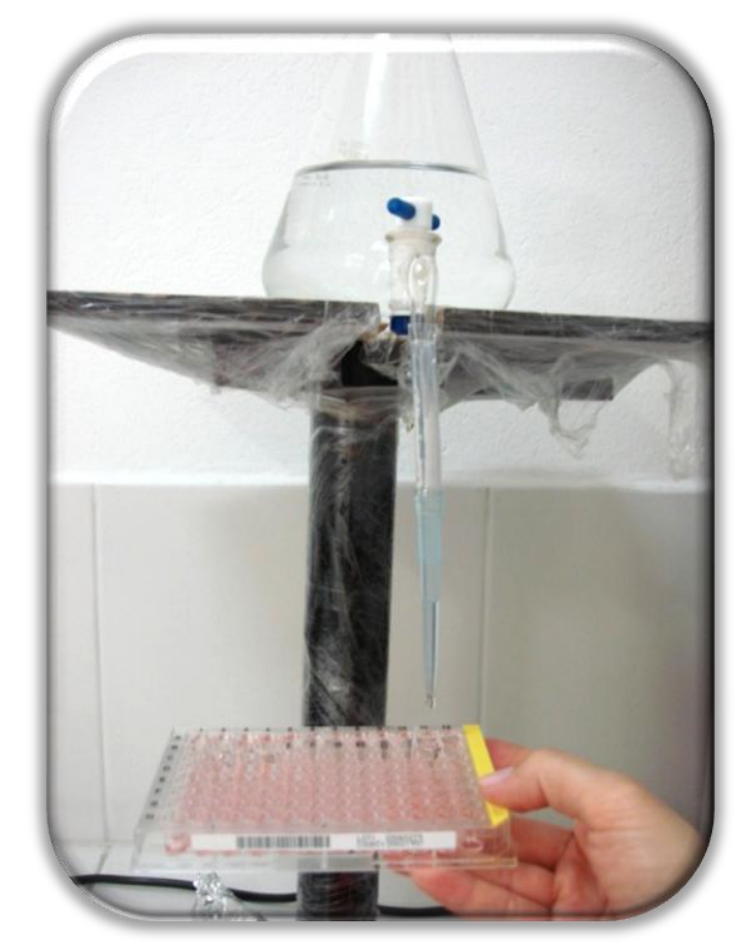

FIGURA 11 - Processo de lavagem da microplaca com PBS

Um volume de $0,2 \mathrm{~mL}$ da solução de extração constituída de ácido acético glacial $0,2 \%$ em etanol (1:1) foi adicionado em cada poço após o processo de lavagem. Como a solução de extração é responsável pela lise da membrana celular ocasionando a liberação do corante contido no interior das células vivas, a quantidade de corante liberada torna-se diretamente proporcional ao número de células sobreviventes após o processo de contato direto com os solutos.

Em prosseguimento, a microplaca foi agitada por 10 minutos e submetida à leitura de densidade óptica (DO) em espectrofotômetro equipado com filtro de $540 \mathrm{~nm}$ (FIG. 12). 


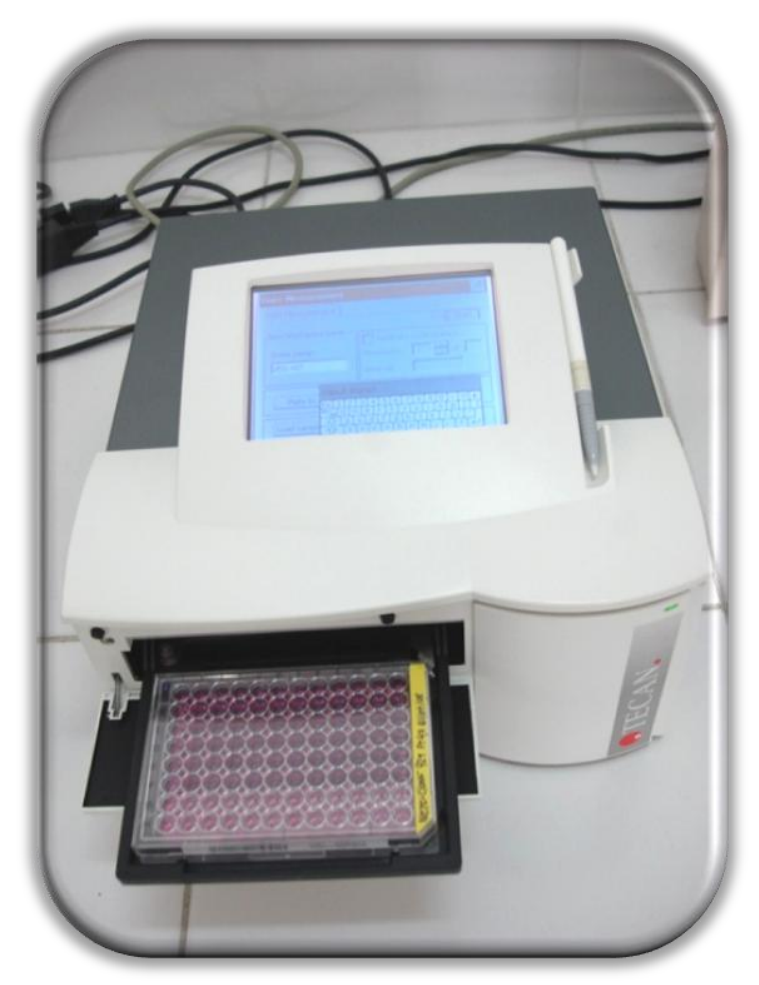

FIGURA 12 - Leitura das DO em espectrofotômetro leitor tipo ELISA

\section{3- Determinação in vitro da dose letal $50 \%\left(\mathrm{DL}_{50}\right)$ da radiação gama}

Visando a obtenção da faixa de dose de radiação a ser utilizada no teste para a determinação do efeito radioprotetor do resveratrol, realizou-se o ensaio in vitro da dose letal $50 \%$ da radiação gama.

Os primeiros ensaios executados para a obtenção da $\mathrm{DL}_{50}$ utilizaram microplacas de 96 poços contendo a cultura celular NCTC Clone 929 em uma densidade de $9,0 \times 10^{4}$ células/poço, preparadas como descrito no item 4.1. Devido ao número exacerbado de células observado após o processamento desses primeiros ensaios, a cultura celular foi utilizada numa densidade inferior $\left(7,0 \times 10^{4}\right.$ células/poço) nos ensaios posteriores.

Inicialmente, as microplacas, contendo a monocamada de células aderidas no interior dos poços, foram submetidas à radiação gama provinda de uma fonte de Cobalto-60 nas doses de 0, 150, 250, 300, 500, 750 e 1000 Gy com uma taxa de dose de 2,75 a 2,44 kGy/hora. A variação da taxa de dose observada corresponde ao decaimento radioativo ocorrido ao longo do período em que foram realizados os ensaios da $\mathrm{DL}_{50}$. 
Para se obter as doses de radiação gama requeridas ao ensaio, foi necessário calcular o tempo de permanência das microplacas no interior do irradiador. Para tal, utilizou-se o valor da taxa de dose correspondente ao mês em que foi realizado cada ensaio. A equação utilizada para este cálculo foi:

\section{Tempo de exposição das microplacas $=$ Dose requerida $/$ Taxa de Dose}

O irradiador GammaCell 200 (FIG. 13 e 14) contém fontes radioativas de Cobalto-60 encapsuladas e blindadas em um contêiner. A disposição planejada dessas fontes no interior do irradiador é o fator essencial para a eficiência e a uniformidade da dose.

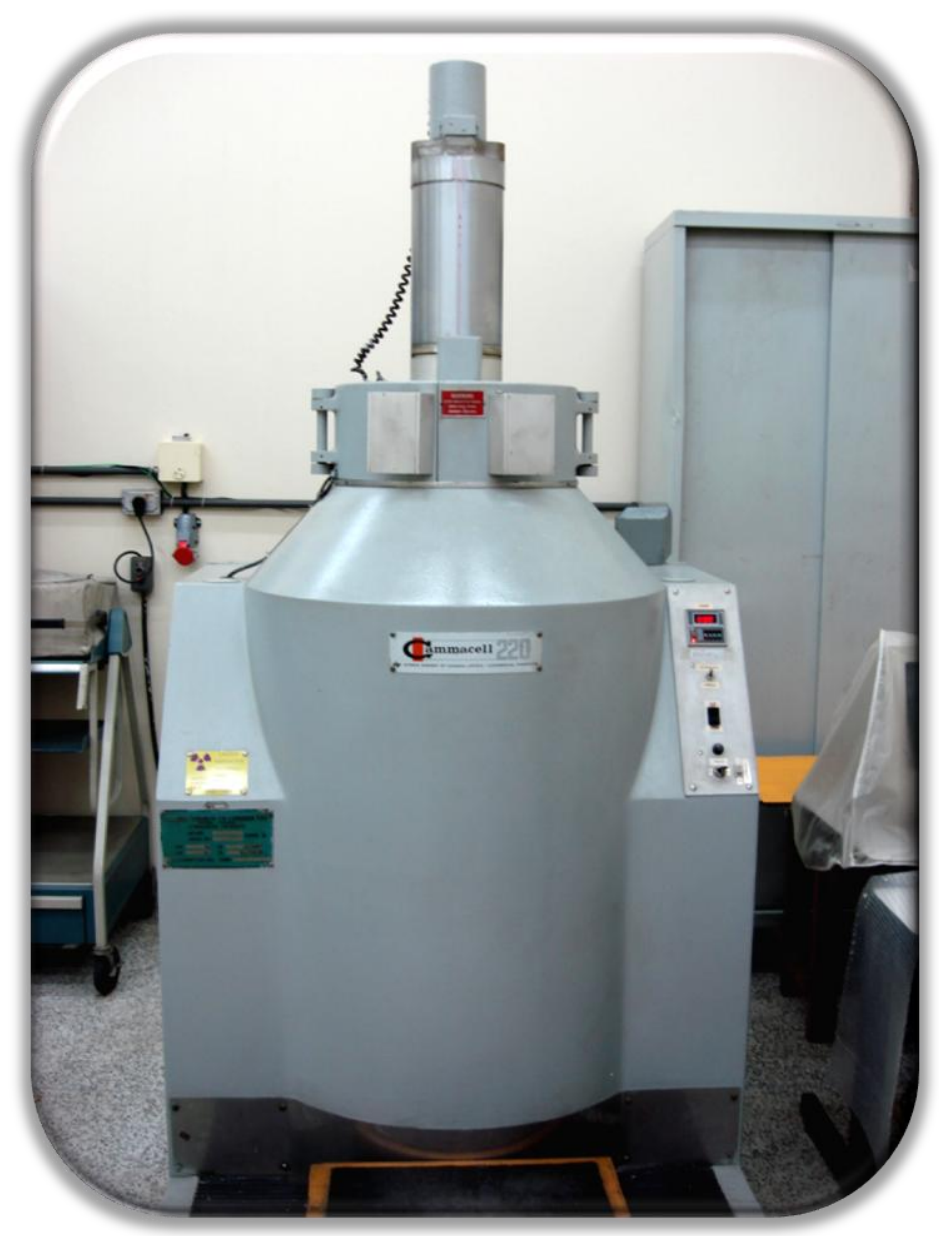

FIGURA 13 - Irradiador GammaCell 200 


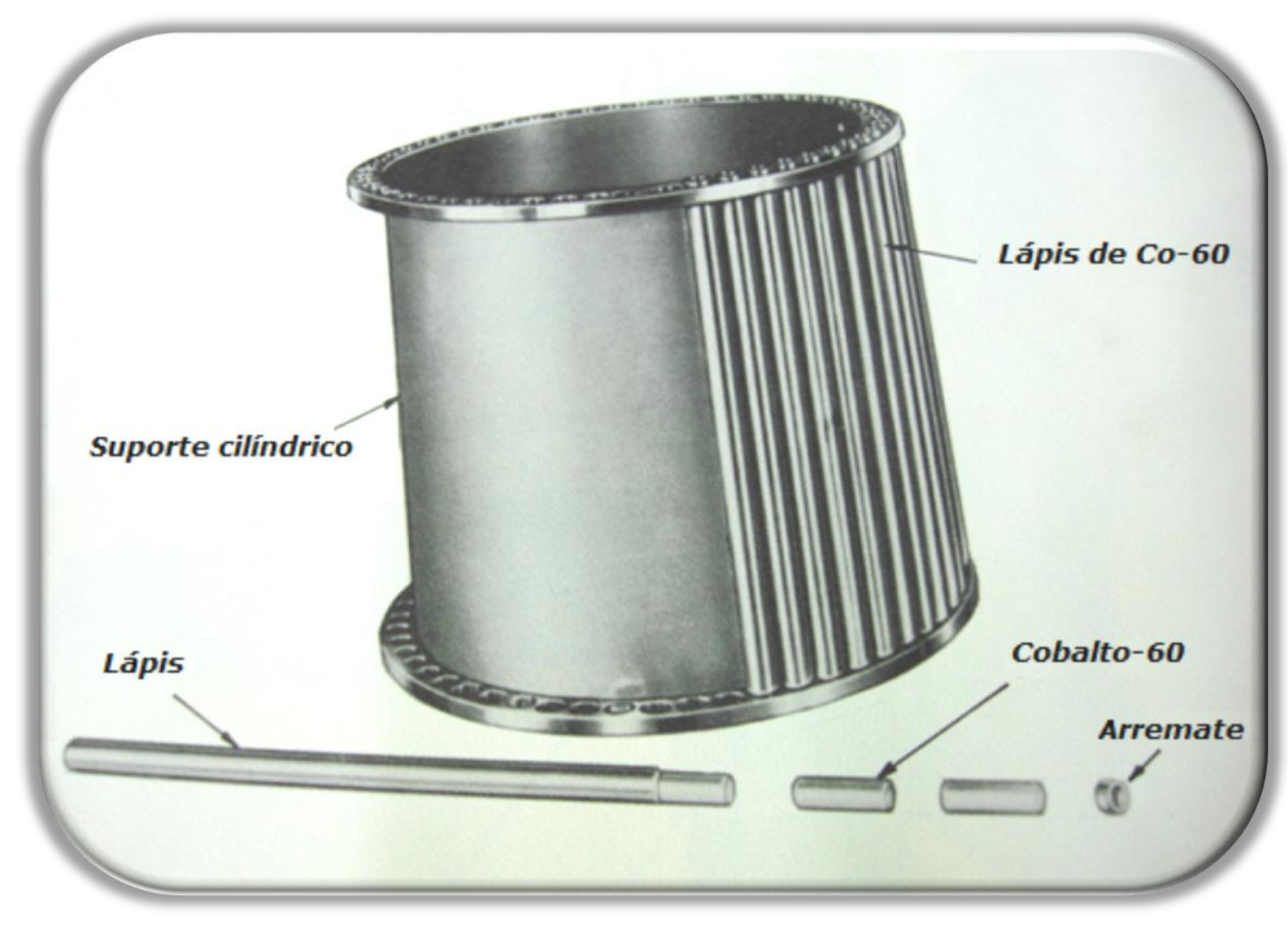

FIGURA 14 - Montagem esquemática das fontes de Cobalto-60 contidas no irradiador GammaCell 200

O controle de células do ensaio foi representado pela microplaca não irradiada, a qual permaneceu protegida da luz e em temperatura ambiente durante o período de irradiação das demais.

Na tentativa de verificar uma possível interferência do MEM contido nas microplacas durante 0 processo de irradiação da cultura celular, foram executadas três metodologias que diferem entre si apenas com relação ao meio no qual a cultura celular foi irradiada, sendo apresentadas em três grupos:

- Grupo (A): cultura celular irradiada logo após a substituição do MEM contido nas microplacas por MEM fresco suplementado com 5\% de SFB;

- Grupo (B): cultura celular irradiada logo após a substituição do MEM contido nas microplacas por PBS;

- Grupo (C): cultura celular irradiada com o MEM já contido nas microplacas.

Após a irradiação, o meio de cultura contido nas microplacas foi substituído por MEM fresco suplementado com 5\% de SFB e as mesmas foram incubadas por 24 horas em estufa a $37^{\circ} \mathrm{C}$ e atmosfera úmida com $5 \%$ de $\mathrm{CO}_{2}$. 
Os procedimentos descritos acima constituem a fase asséptica do ensaio. Para tal, a esterilização do laboratório com luz UV e a utilização do fluxo laminar durante a manipulação das microplacas e dos materiais esterilizados, foram imprescindíveis.

Em seqüência, os procedimentos de incorporação do corante vermelho neutro, lavagem das células e leitura das densidades ópticas decorreram como descritos no item 4.2 .

Visando a verificação da metodologia, foram efetuados, em períodos diferentes, dois ensaios do Grupo (A), um ensaio do Grupo (B) e três ensaios do Grupo (C). O número de ensaios realizados foi estipulado em decorrência da necessidade encontrada ao longo do estudo.

\section{4- Determinação in vitro do efeito radioprotetor do resveratrol}

O efeito radioprotetor do resveratrol foi verificado em cultura de célula da linhagem NCTC Clone 929 do ATCC distribuída em microplacas de 96 poços a uma densidade de 2,0 × $10^{4}$ células/poço, preparadas como descrito no item 4.1.

Neste teste biológico foram utilizadas soluções de resveratrol em concentrações inferiores ao $\mathrm{IC}_{50 \%}$ obtido no teste in vitro de citotoxicidade, descrito no item 4.2. Para tal, uma solução alcoólica de resveratrol na concentração inicial de $1,0 \times 10^{4} \mu \mathrm{M} / \mathrm{L}$ foi preparada e, efetuando-se diluições em MEM contendo 5\% de SFB, soluções nas concentrações de 30, 25, 12,5, e 6,25 $\mu \mathrm{M} / \mathrm{L}$ foram obtidas. A esterilização destas soluções foi realizada com auxílio de um sistema de membranas contendo poros de 0,22 $\mu \mathrm{m}$ de diâmetro.

Um volume de 0,2 $\mathrm{mL}$ das soluções de resveratrol foi distribuído nos poços das microplacas contendo as células aderidas, depositando-se em cada microplaca apenas uma concentração de resveratrol (FIG. 15). As microplacas que representaram a concentração de $0 \mu \mathrm{M} / \mathrm{L}$ de resveratrol receberam apenas MEM com $5 \%$ de SFB. 


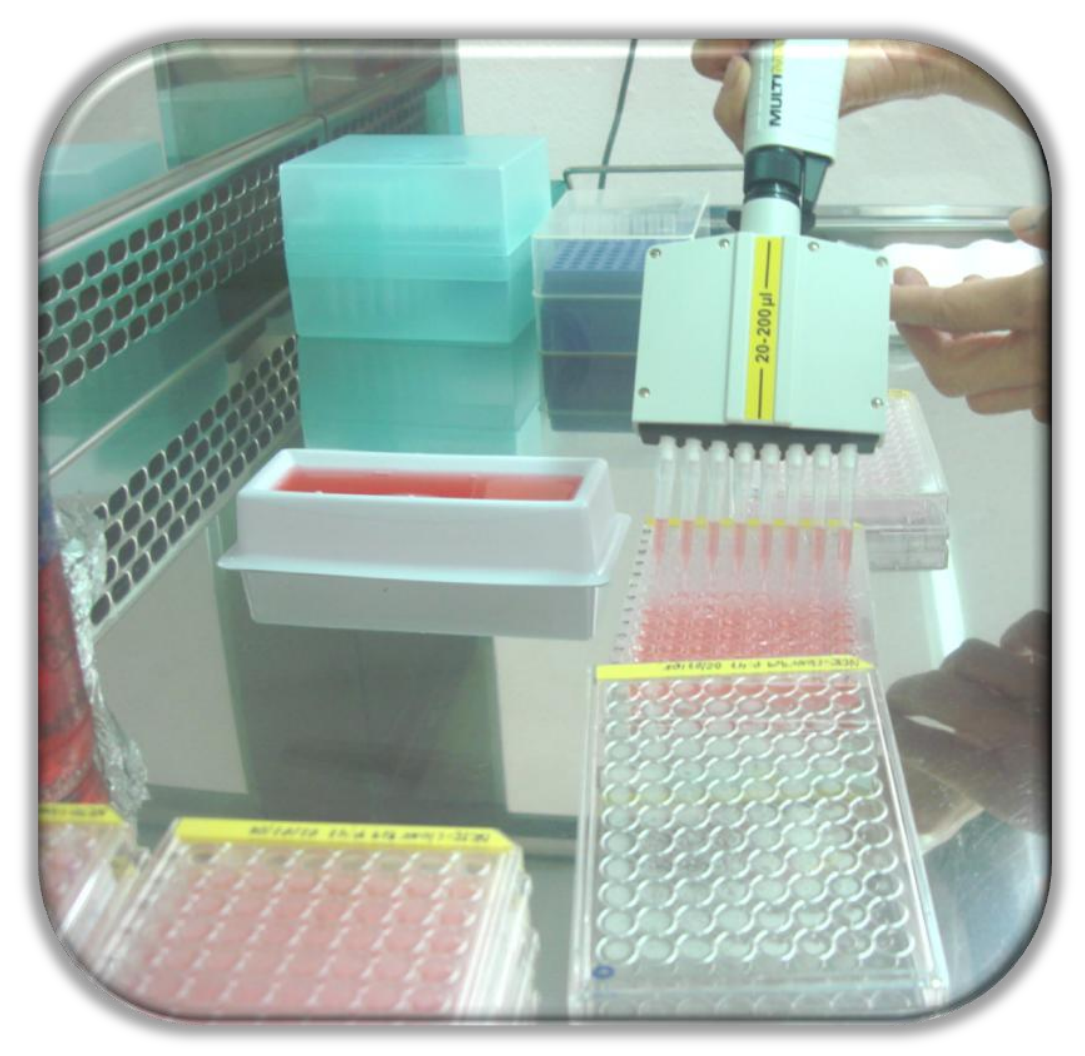

FIGURA 15 - Distribuição da solução de resveratrol na microplaca de cultura celular visando à determinação in vitro do efeito radioprotetor do composto

Concluída a distribuição das soluções nos poços, as microplacas foram incubadas por 24 horas a $37^{\circ} \mathrm{C}$ em atmosfera úmida contendo $5 \%$ de $\mathrm{CO}_{2}$. Esse período de incubação foi necessário para a incorporação do resveratrol pelas células em cultura.

Decorrido este período, as microplacas foram submetidas a doses únicas de radiação gama. A faixa de dose foi estabelecida pelo valor da $D L_{50}$ obtido no ensaio in vitro da dose letal $50 \%$ da radiação gama descrito no item 4.3.

As doses de radiação gama utilizadas neste ensaio foram de 300, 500 e 800 Gy com taxa de dose de 2,28 kGy/hora. As microplacas não irradiadas (0 Gy) permaneceram protegidas da luz e em temperatura ambiente durante 0 período de irradiação das demais microplacas.

O tempo de permanência das microplacas no interior do irradiador GammaCell 200, para a obtenção da dose de radiação necessária ao ensaio, foi calculado pela equação descrita no item 4.3. 
Após a irradiação, o meio de cultura de todas as microplacas foi substituído por MEM fresco suplementado com $5 \%$ de SFB e as mesmas foram incubadas por 24 horas em estufa a $37^{\circ} \mathrm{C}$ e atmosfera úmida com $5 \%$ de $\mathrm{CO}_{2}$ (FIG. 16) finalizando a fase asséptica do ensaio.

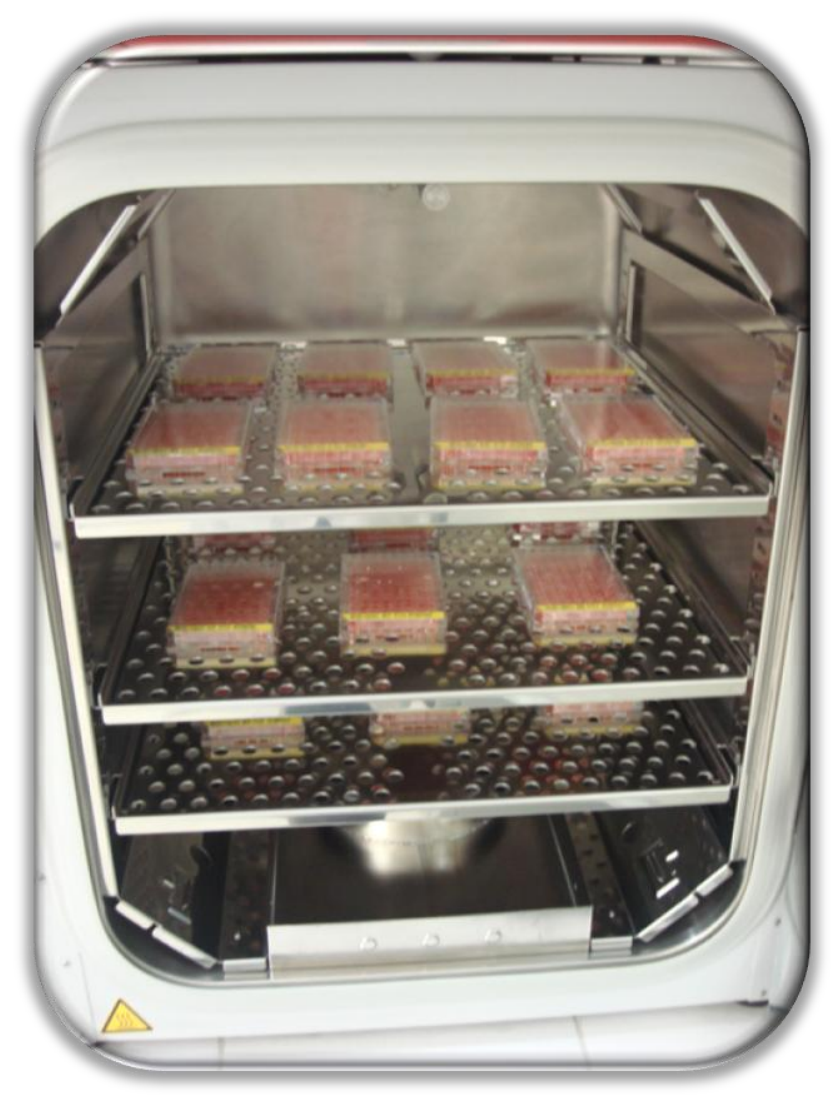

FIGURA 16 - Microplacas em estufa a $37^{\circ} \mathrm{C}$ e atmosfera úmida com $5 \%$ de $\mathrm{CO}_{2}$

Em seqüência, os procedimentos de incorporação do corante vermelho neutro, lavagem das células e leitura das densidades ópticas decorreram como descritos no item 4.2.

A metodologia descrita acima foi obtida após efetuar alguns ajustes na técnica dos primeiros ensaios realizados para a verificação do efeito radioprotetor do resveratrol.

Inicialmente, os ensaios de radioproteção do resveratrol foram realizados em microplacas contendo cultura celular numa densidade semelhante à utilizada nos testes de $\mathrm{IC}_{50 \%}$ do resveratrol e da $\mathrm{DL}_{50}$ da radiação gama 


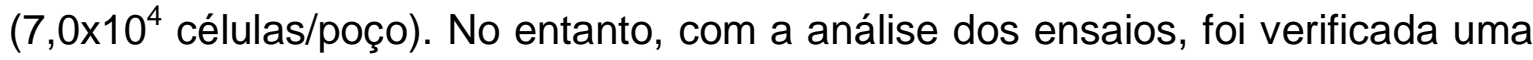
incoerência nos valores de viabilidade celular obtidos nas microplacas irradiadas sem a prévia exposição ao resveratrol $(0 \mu \mathrm{M} / \mathrm{L}$ de resveratrol), observando-se uma curva de viabilidade celular com um perfil diferente ao apresentado pelo teste da $\mathrm{DL}_{50}$ da radiação gama.

$\mathrm{Na}$ tentativa de eliminar o fator responsável por essa incoerência e verificar a reprodutibilidade do teste, foram efetuados oito ensaios em períodos diferentes. Esses ensaios foram realizados com alterações metodológicas restritas apenas ao processo de distribuição das soluções nos poços das microplacas, ao meio contido na microplaca durante a irradiação e ao processo de irradiação, sendo totalizados quatro grupos de estudo:

- Grupo (A): constitui os primeiros ensaios efetuados para determinar o efeito radioprotetor do resveratrol;

- Distribuição das soluções de resveratrol nas microplacas: em triplicata;

- Meio contido na microplaca durante a irradiação: soluções de resveratrol.

- Grupo (B):

- Distribuição das soluções de resveratrol nas microplacas: em triplicata;

- Meio contido na microplaca durante a irradiação: PBS.

- Grupo (C):

- Distribuição das soluções de resveratrol nas microplacas: em triplicata;

- Meio contido na microplaca durante a irradiação: soluções de resveratrol;

- Processo de irradiação das microplacas: individualizado.

- Grupo (D):

- Distribuição das soluções de resveratrol nas microplacas: uma concentração de resveratrol em cada microplaca;

- Meio contido na microplaca durante a irradiação: soluções de resveratrol.

No entanto, a incoerência nos valores de viabilidade celular persistiu nestes quatro grupos de ensaios analisados.

Visando o aperfeiçoamento da metodologia, foram realizados mais três ensaios alterando-se a densidade da cultura celular. 
Na primeira tentativa, microplacas com cultura celular numa densidade de 5,0 $\times 10^{4}$ células/poço foram utilizadas e os resultados foram semelhantes aos obtidos nos ensaios anteriormente realizados com 7,0 × 10 ${ }^{4}$ células/poço.

Numa nova análise, a densidade celular foi alterada para $2,0 \times 10^{4}$ células/poço e os resultados foram satisfatórios. 


\section{5- RESULTADOS E DISCUSSÃO}

\section{1- Determinação in vitro do índice de citotoxicidade $\left(\mathrm{IC}_{50 \%}\right)$ do resveratrol}

No estudo da toxicidade do resveratrol, a DO obtida de cada poço da microplaca foi transcrita para o programa "Microsoft Office Excel" visando o cálculo dos valores médios das DO e seus respectivos desvios padrão, cujos valores representam os efeitos celulares promovidos durante o período de contato direto do resveratrol e dos extratos dos controles positivo e negativo com a cultura celular, e o cálculo das porcentagens de viabilidade celular efetuado em relação ao controle de células do ensaio.

Os valores da TAB. 1 expressam as médias das DO apresentadas pelas microplacas submetidas a diferentes concentrações de resveratrol durante os ensaios in vitro de citotoxicidade do composto.

TABELA 1 - Médias das DO referentes às diferentes concentrações de resveratrol obtidas nos ensaios de citotoxicidade

Concentração de Resveratrol ( $\mu \mathrm{M} / \mathrm{L})$

$\begin{array}{lllll}15,65 & 31,25 & 62,5 & 125 & 250\end{array}$
Ensaio $1 \quad 0,62 \pm 0,07$
$0,64 \pm 0,08$
$0,21 \pm 0,02$
$0,03 \pm 0,00$
$0,00 \pm 0,00$
Ensaio $2 \quad 0,51 \pm 0,03$
$0,57 \pm 0,04 \quad 0,20 \pm 0,02$
$0,16 \pm 0,03$
$0,01 \pm 0,00$

Os controles positivo e negativo são importantes para a verificação da eficácia do ensaio in vitro de citotoxicidade. Os dados das TAB. 2 e 3 representam as médias das DO referentes aos controles positivo e negativo, respectivamente. 
TABELA 2 - Médias das DO referentes às diferentes concentrações do controle positivo obtidas nos ensaios de citotoxicidade do resveratrol

Concentração do Controle Positivo (\%)

$\begin{array}{lllll}6,25 & 12,5 & 25 & 50 & 100\end{array}$
Ensaio $1 \quad 0,68 \pm 0,09$
$0,56 \pm 0,03$
$0,58 \pm 0,10$
$0,27 \pm 0,01$
$0,00 \pm 0,00$
Ensaio $2 \quad 0,58 \pm 0,03$
$0,55 \pm 0,02$
$0,58 \pm 0,04$
$0,62 \pm 0,10$
$0,02 \pm 0,00$

TABELA 3 - Médias das DO referentes às diferentes concentrações do controle negativo obtidas nos ensaios de citotoxicidade do resveratrol

\begin{tabular}{cccccc}
\hline \multicolumn{5}{c}{ Concentração do Controle Negativo (\%) } \\
\cline { 2 - 6 } & 6,25 & 12,5 & 25 & 50 & 100 \\
\hline Ensaio1 & $0,71 \pm 0,10$ & $0,66 \pm 0,11$ & $0,73 \pm 0,07$ & $0,77 \pm 0,09$ & $0,61 \pm 0,06$ \\
Ensaio2 & $0,51 \pm 0,08$ & $0,52 \pm 0,04$ & $0,56 \pm 0,03$ & $0,58 \pm 0,07$ & $0,53 \pm 0,02$ \\
\hline
\end{tabular}

O controle de células do ensaio in vitro de citotoxicidade representa $100 \%$ de viabilidade celular. Os valores médios das DO, assim como as porcentagens de viabilidade celular obtidos pelo controle de células dos ensaios de citotoxicidade do resveratrol estão expressos na TAB. 4.

TABELA 4 - Médias das DO e porcentagens de viabilidade celular referentes ao controle de células dos ensaios de citotoxicidade do resveratrol

\begin{tabular}{lcc}
\hline & Ensaio 1 & Ensaio 2 \\
\hline Média das Do & $0,70 \pm 0,12$ & $0,49 \pm 0,08$ \\
Viabilidade Celular (\%) & $100,00 \pm 17,66$ & $100,00 \pm 16,52$ \\
\hline
\end{tabular}


Com a média das DO determinada para cada concentração do resveratrol e dos extratos dos controles positivo e negativo, foi possível calcular as porcentagens de viabilidade celular pela equação:

\section{$\%$ Viabilidade Celular $=\left(\mathrm{DO}_{\mathrm{SL}} \times 100\right) / \mathrm{DO}_{\mathrm{CC}}$}

Onde, $\mathrm{DO}_{\mathrm{SL}}$ representa o valor médio das DO de cada diluição do resveratrol e dos extratos dos controles positivo e negativo e $\mathrm{DO}_{\mathrm{CC}}$, o valor médio das DO apresentado pelo controle de células.

Os valores de viabilidade celular obtidos pela exposição direta da cultura de células às soluções de resveratrol e aos controles positivo e negativo estão registrados nas TAB. 5, 6 e 7, respectivamente.

TABELA 5 - Porcentagens de viabilidade celular referentes às diferentes concentrações de resveratrol obtidas no ensaio de citotoxicidade

Concentração de Resveratrol ( $\mu \mathrm{M} / \mathrm{L})$

$\begin{array}{lllll}15,63 & 31,25 & 62,5 & 125 & 250\end{array}$

Ensaio $1 \quad 88,31 \pm 11,98 \quad 90,55 \pm 12,10 \quad 30,12 \pm 7,00 \quad 4,18 \pm 5,21 \quad 0,62 \pm 13,32$

Ensaio $2 \quad 103,65 \pm 6,28 \quad 115,26 \pm 7,22 \quad 15,80 \pm 10,96 \quad 2,43 \pm 10,52 \quad 1,51 \pm 8,95$

TABELA 6 - Porcentagens de viabilidade celular referentes às diferentes concentrações do controle positivo obtidas no ensaio de citotoxicidade do resveratrol

Concentração do Controle Positivo (\%)

$\begin{array}{lllll}6,25 & 12,5 & 25 & 50 & 100\end{array}$

Ensaio $1 \quad 96,20 \pm 13,71 \quad 79,63 \pm 5,13 \quad 82,95 \pm 16,85 \quad 38,70 \pm 5,26 \quad 0,50 \pm 20,02$

Ensaio $2 \quad 116,90 \pm 4,78 \quad 111,90 \pm 3,27 \quad 117,72 \pm 6,13 \quad 126,37 \pm 15,35 \quad 3,35 \pm 12,86$ 
TABELA 7 - Porcentagens de viabilidade celular referentes às diferentes concentrações do controle negativo obtidas no ensaio de citotoxicidade do resveratrol

\section{Concentração do Controle Negativo (\%)}

$\begin{array}{lllll}6,25 & 12,5 & 25 & 50 & 100\end{array}$

Ensaio1 $100,38 \pm 13,68 \quad 93,73 \pm 17,11 \quad 104,61 \pm 9,33 \quad 109,40 \pm 11,28 \quad 86,33 \pm 9,11$

Ensaio2 $\quad 104,12 \pm 14,90 \quad 104,80 \pm 7,24 \quad 113,39 \pm 5,13 \quad 116,57 \pm 11,56 \quad 108,32 \pm 3,51$

Para a estimativa do $\mathrm{IC}_{50 \%}$, foram calculados os valores médios das porcentagens de viabilidade celular obtidas nos ensaios 1 e 2 de citotoxicidade do resveratrol (TAB. 8).

TABELA 8 - Concentrações do resveratrol e dos extratos dos controles positivo e negativo e suas respectivas porcentagens de viabilidade celular obtidas pela média dos resultados apresentados pelos ensaios 1 e 2 de citotoxicidade do resveratrol

\begin{tabular}{ccccc}
\hline \multirow{2}{*}{ Diluição (\%) } & \multirow{2}{*}{$\begin{array}{c}\text { Concentração do } \\
\text { resveratrol }(\mu \mathrm{M} / \mathrm{L})\end{array}$} & \multirow{2}{*}{ Resveratrol } & \multicolumn{2}{c}{ Controles } \\
\cline { 3 - 5 } & & & Positivo & Negativo \\
\hline 6,25 & 15,63 & $95,98 \pm 9,13$ & $106,55 \pm 9,25$ & $102,25 \pm 14,29$ \\
12,5 & 31,25 & $102,91 \pm 9,66$ & $95,77 \pm 4,20$ & $99,27 \pm 12,18$ \\
25 & 62,5 & $22,96 \pm 8,98$ & $100,34 \pm 11,49$ & $109,00 \pm 7,23$ \\
50 & 125 & $3,31 \pm 7,87$ & $82,54 \pm 10,31$ & $112,99 \pm 11,42$ \\
100 & 250 & $1,07 \pm 11,14$ & $1,93 \pm 16,44$ & $97,33 \pm 6,31$ \\
\hline
\end{tabular}

O índice de citotoxicidade $\left(\mathrm{IC}_{50 \%}\right)$ indica a concentração do soluto que reduz em $50 \%$ a viabilidade da população celular utilizada no ensaio. Para a sua 
estimativa, os dados da TAB. 8 foram projetados em gráfico com a viabilidade celular (\%) em função das concentrações do resveratrol e dos extratos dos controles positivo e negativo (\%).

A FIG. 17 ilustra as curvas de viabilidade celular obtidas no ensaio in vitro de citotoxicidade do resveratrol.

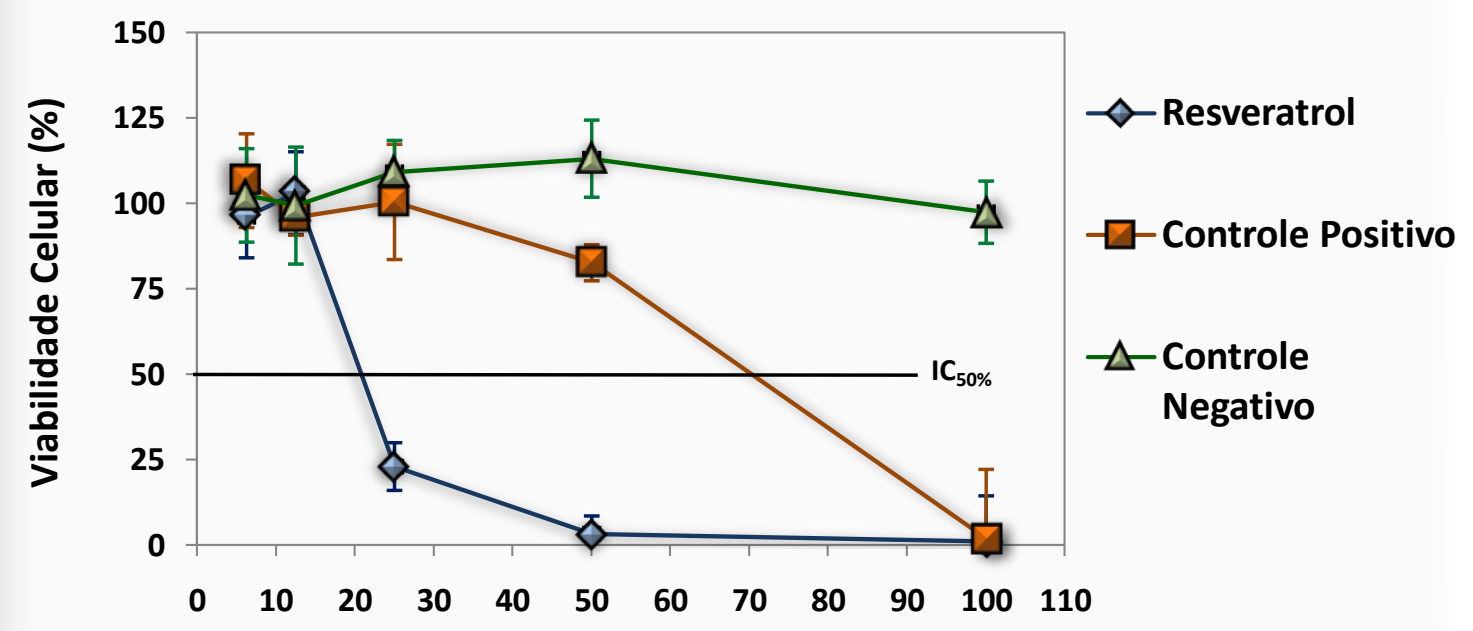

Concentração do Resveratrol e dos Extratos (\%)

FIGURA 17 - Curvas de viabilidade celular obtidas no ensaio in vitro de citotoxicidade do resveratrol

Na análise gráfica da toxicidade dos compostos é verificada a posição das curvas de viabilidade celular em relação à linha do $\mathrm{IC}_{50 \%}$.

O composto, cuja curva de viabilidade celular se projeta acima da linha do $\mathrm{IC}_{50 \%}$, é considerado não tóxico, como verificado no controle negativo. Já o composto que exibe uma curva de viabilidade celular abaixo ou transpondo a linha do $\mathrm{IC}_{50 \%}$, é considerado tóxico.

O $I C_{50 \%}$ é estimado na intersecção entre a linha do $I_{50 \%}$ e a curva de viabilidade celular obtida em gráfico. Logo, o controle positivo apresentou um $\mathrm{IC}_{50 \%}$ de aproximadamente $70 \%$. 
A curva de viabilidade celular do resveratrol demonstrou um perfil semelhante ao do controle positivo, sendo obtido um $\mathrm{IC}_{50 \%}$ de aproximadamente $20 \%$, valor este correspondente à concentração de $50 \mu \mathrm{M} / \mathrm{L}$.

O IC $\mathrm{I}_{50 \%}$ obtido neste ensaio encontra-se em conformidade com os valores relatados pela literatura, 20-100 $\mu \mathrm{M} / \mathrm{L}$ (Sgambato et al., 2001).

Este teste biológico proporcionou a estimava de uma faixa de concentração do resveratrol adequada ao estudo para a determinação da atividade radioprotetora do composto.

\section{2- Determinação in vitro da dose letal $50 \%\left(\mathrm{DL}_{50}\right)$ da radiação gama}

O teste biológico da dose letal $50 \%$ da radiação gama $\left(\mathrm{DL}_{50}\right)$ foi realizado para definir a dose de radiação que promove $50 \%$ de morte celular da população utilizada no ensaio.

Os valores das densidades ópticas (DO) obtidas nos ensaios da $\mathrm{DL}_{50}$ foram transcritos para o programa "Microsoft Office Excel", permitindo o cálculo das médias das DO, cujos valores representam os efeitos celulares promovidos pela ação da radiação gama, assim como as porcentagens de viabilidade celular em relação ao controle de células do ensaio.

O controle de células consiste na microplaca não submetida à radiação gama, representando $100 \%$ de sobrevida celular.

A porcentagem de viabilidade celular proporcionada pelas diferentes doses de radiação gama foi calculada pela equação:

\section{$\%$ Viabilidade Celular $=\left(\mathrm{DO}_{\mathrm{MI}} \times 100\right) / \mathrm{DO}_{\mathrm{CC}}$}

Onde, $\mathrm{DO}_{\mathrm{MI}}$ : Densidade óptica das microplacas irradiadas; $\mathrm{DO}_{\mathrm{CC}}$ : Densidade óptica do controle de células do ensaio.

Os dois primeiros ensaios de $\mathrm{DL}_{50}$ foram realizados em cultura celular numa densidade de 9,0 × $10^{4}$ células/poço, cujos valores médios de DO obtidos estão expressos na TAB. 9. 
TABELA 9 - Médias das DO obtidas nas diferentes doses de radiação gama referentes aos ensaios realizados em cultura celular com densidade de $9,0 \times 10^{4}$ células/poço

\begin{tabular}{ccc}
\hline \multirow{2}{*}{$\begin{array}{c}\text { Dose de Radiação Gama } \\
\text { (Gy) }\end{array}$} & Ensaios \\
\cline { 2 - 3 } 0 & $0,55 \pm 0,08$ & Ensaio 2 \\
10 & $0,44 \pm 0,07$ & $0,387 \pm 0,07$ \\
10 & $0,34 \pm 0,07$ & $/$ \\
30 & $0,42 \pm 0,05$ & $/$ \\
50 & $0,39 \pm 0,05$ & $/$ \\
75 & $0,39 \pm 0,08$ & \\
200 & $/$ & $0,43 \pm 0,08$ \\
400 & $/$ & $0,29 \pm 0,04$
\end{tabular}

Com base nos dados da TAB. 9, as porcentagens de viabilidade celular foram calculadas (TAB. 10). 
TABELA 10 - Porcentagens de viabilidade celular obtidas nas diferentes doses de radiação gama referentes aos ensaios realizados em cultura celular com densidade de $9,0 \times 10^{4}$ células/poço

\begin{tabular}{ccc}
\hline \multirow{2}{*}{$\begin{array}{c}\text { Dose de Radiação Gama } \\
\text { (Gy) }\end{array}$} & \multicolumn{2}{c}{ Ensaios } \\
\cline { 2 - 3 } 0 & $100,00 \pm 13,96$ & Ensaio 2 \\
10 & $79,64 \pm 15,40$ & $/$ \\
10 & $61,90 \pm 19,14$ & $/$ \\
30 & $76,14 \pm 11,13$ & $/$ \\
50 & $71,33 \pm 12,80$ & $/$ \\
75 & $71,58 \pm 20,03$ & $/$ \\
200 & $/$ & $112,16 \pm 18,67$ \\
400 & $/$ & $74,08 \pm 13,74$
\end{tabular}

Projetando-se os valores da TAB. 10 em gráfico, sendo traçado a porcentagem de viabilidade celular em função das doses de radiação gama, obteve-se as primeiras tentativas de estimar a $\mathrm{DL}_{50}$ da radiação gama (FIG. 18). 


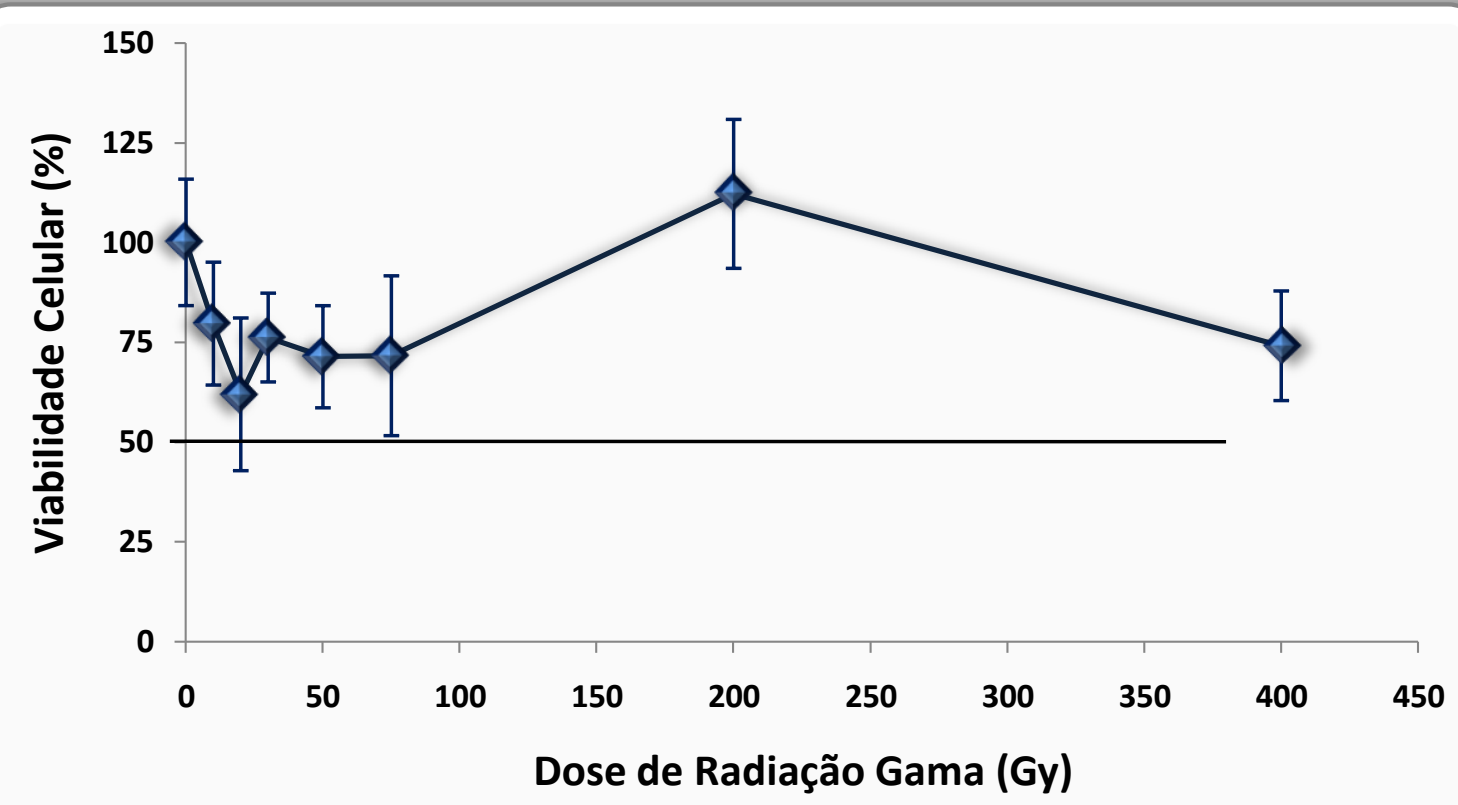

FIGURA 18 - Curva de viabilidade celular obtida no teste in vitro da $\mathrm{DL}_{50}$ da radiação gama referente aos ensaios realizados em cultura celular com densidade de $9,0 \times 10^{4}$ células/poço

Pela análise gráfica da curva de viabilidade celular apresentada na FIG. 18, observou-se que na faixa de dose de radiação gama utilizada nos dois primeiros ensaios da $\mathrm{DL}_{50}$ todos os valores de viabilidade celular foram superiores ou próximos a $50 \%$, não se obtendo a morte da metade da população celular analisada. Este fato foi justificado pelo elevado número de células da cultura celular.

Visando uma nova tentativa para a obtenção da $\mathrm{DL}_{50}$, foram realizados ensaios em cultura celular com densidade de $7,0 \times 10^{4}$ células/poço, cuja metodologia foi executada em três grupos que diferem entre si apenas com relação ao meio no qual a cultura celular foi irradiada, sendo eles:

- Grupo (A), cultura celular irradiada logo após a substituição do MEM contido nas microplacas por MEM suplementado com $5 \%$ de SFB;

- Grupo (B), cultura celular irradiada logo após a substituição do MEM contido nas microplacas por PBS;

- Grupo (C), cultura celular irradiada com o MEM já contido nas microplacas. 
Os valores médios das DO obtidos nos ensaios dos grupos (A), (B) e (C) estão expressos nas TAB. 11, 12 e 13, respectivamente.

TABELA 11 - Médias das DO obtidas nas diferentes doses de radiação gama referentes aos ensaios do Grupo $(A)$

\begin{tabular}{cccccccc}
\hline $\begin{array}{c}\text { Grupo } \\
\text { (A) }\end{array}$ & \multicolumn{7}{l}{ Dose de Radiação Gama (Gy) } \\
\cline { 2 - 8 } & 0 & 150 & 250 & 300 & 500 & 750 & 1000 \\
\hline Ensaio 1 & $0,41 \pm 0,06$ & $0,35 \pm 0,03$ & $/$ & $0,35 \pm 0,06$ & $0,26 \pm 0,05$ & $/$ & $/$ \\
Ensaio 2 & $0,49 \pm 0,08$ & $/$ & $0,29 \pm 0,06$ & $/$ & $0,14 \pm 0,02$ & $0,14 \pm 0,02$ & $0,16 \pm 0,03$
\end{tabular}

Grupo (A): Cultura celular irradiada logo após a substituição do MEM contido nas microplacas por MEM suplementado com $5 \%$ de SFB.

TABELA 12 - Médias das DO obtidas nas diferentes doses de radiação gama referentes ao ensaio do Grupo (B)

\begin{tabular}{cccccc}
\hline \multirow{2}{*}{ Grupo (B) } & \multicolumn{6}{l}{ Dose de Radiação Gama (Gy) } \\
\cline { 2 - 6 } & 0 & 250 & 500 & 750 & 1000 \\
\hline Ensaio 3 & $0,49 \pm 0,07$ & $0,28 \pm 0,06$ & $0,12 \pm 0,02$ & $0,08 \pm 0,01$ & $0,04 \pm 0,01$
\end{tabular}

Grupo (B): Cultura celular irradiada logo após a substituição do MEM contido nas microplacas por PBS. 
TABELA 13 - Médias das DO obtidas nas diferentes doses de radiação gama referentes aos ensaios do Grupo (C)

\begin{tabular}{cccccc}
\hline \multirow{6}{*}{ Grupo (C) } & \multicolumn{6}{l}{ Dose de Radiação Gama (Gy) } \\
\cline { 2 - 6 } & $\mathbf{0}$ & 250 & 500 & 750 & 1000 \\
\hline Ensaio 4 & $0,39 \pm 0,07$ & $0,30 \pm 0,05$ & $0,09 \pm 0,02$ & $0,06 \pm 0,01$ & $0,05 \pm 0,01$ \\
Ensaio 5 & $0,40 \pm 0,07$ & $0,22 \pm 0,04$ & $0,16 \pm 0,03$ & $/$ & $/$ \\
\hline
\end{tabular}

Grupo (C): Cultura celular irradiada com o MEM já contido nas microplacas.

Efetuando-se o cálculo das porcentagens de viabilidade celular em relação ao controle de células, foram obtidos os valores apresentados nas TAB. 14,15 e 16.

TABELA 14 - Porcentagens de viabilidade celular obtidas nas diferentes doses de radiação gama referentes aos ensaios do Grupo $(A)$

\begin{tabular}{|c|c|c|c|c|c|c|c|}
\hline \multirow{2}{*}{ Grupo (A) } & \multicolumn{7}{|c|}{ Dose de Radiação Gama (Gy) } \\
\hline & 0 & 150 & 250 & 300 & 500 & 750 & 1000 \\
\hline Ensaio 1 & $\begin{array}{r}100,00 \\
\pm 15,44\end{array}$ & $\begin{array}{l}83,91 \\
\pm 9,19\end{array}$ & I & $\begin{array}{c}85,51 \\
\pm 15,74\end{array}$ & $\begin{array}{c}62,93 \\
\pm 20,40\end{array}$ & l & / \\
\hline Ensaio 2 & $\begin{array}{r}100,00 \\
\pm 16,87\end{array}$ & / & $\begin{array}{c}59,26 \\
\pm 19,88\end{array}$ & / & $\begin{array}{c}29,14 \\
\pm 12,24\end{array}$ & $\begin{array}{c}28,59 \\
\pm 16,26\end{array}$ & $\begin{array}{r}31,38 \\
\pm 19,19\end{array}$ \\
\hline
\end{tabular}

Grupo (A): Cultura celular irradiada logo após a substituição do MEM contido nas microplacas por MEM suplementado com $5 \%$ de SFB. 
TABELA 15 - Porcentagens de viabilidade celular obtidas nas diferentes doses de radiação gama referentes ao ensaio do Grupo (B)

\begin{tabular}{cccccc}
\hline \multirow{6}{*}{ Grupo (B) } & \multicolumn{5}{l}{ Dose de Radiação Gama (Gy) } \\
\cline { 2 - 6 } & 0 & 250 & 500 & 750 & 1000 \\
\hline \multirow{2}{*}{ Ensaio 3 } & $100 \pm 14,45$ & $57,65 \pm 19,96$ & $24,40 \pm 14,57$ & $17,11 \pm 14,35$ & $8,01 \pm 18,82$
\end{tabular}

Grupo (B): Cultura celular irradiada logo após a substituição do MEM contido nas microplacas por PBS.

TABELA 16 - Porcentagens de viabilidade celular obtidas nas diferentes doses de radiação gama referentes aos ensaios do Grupo (C)

\begin{tabular}{|c|c|c|c|c|c|}
\hline \multirow{2}{*}{$\begin{array}{c}\text { Grupo } \\
\text { (C) }\end{array}$} & \multicolumn{5}{|c|}{ Dose de Radiação Gama (Gy) } \\
\hline & 0 & 250 & 500 & 750 & 1000 \\
\hline Ensaio 4 & $100,00 \pm 16,55$ & $75,69 \pm 17,85$ & $23,72 \pm 19,82$ & $16,22 \pm 20,45$ & $13,80 \pm 19,99$ \\
\hline Ensaio 5 & $100,00 \pm 17,43$ & $54,00 \pm 20,38$ & $39,71 \pm 15,57$ & l & / \\
\hline
\end{tabular}

Grupo (C): Cultura celular irradiada com o MEM já contido nas microplacas.

Os resultados expressos na TAB. 17 indicam os valores médios de viabilidade celular calculados para cada grupo de ensaios. 
TABELA 17 - Médias das porcentagens de viabilidade celular obtidas nas diferentes doses de radiação gama referentes aos três grupos de ensaios

\begin{tabular}{cccc}
\hline Dose de Radiação Gama \\
(Gy) & \multicolumn{4}{c}{ Grupos } \\
\cline { 2 - 4 } 0 & Grupo (A) & Grupo (B) & Grupo (C) \\
\hline 150 & $100,00 \pm 16,16$ & $100,00 \pm 14,45$ & $100,00 \pm 16,99$ \\
250 & $83,91 \pm 9,19$ & $/$ & $/$ \\
300 & $59,26 \pm 19,88$ & $57,65 \pm 19,96$ & $64,85 \pm 19,12$ \\
500 & $85,51 \pm 15,74$ & $/$ & $/$ \\
750 & $46,04 \pm 16,32$ & $24,40 \pm 14,57$ & $31,72 \pm 17,70$ \\
1000 & $28,59 \pm 16,26$ & $17,11 \pm 14,35$ & $16,22 \pm 20,45$ \\
& $31,38 \pm 19,19$ & $8,01 \pm 18,82$ & $13,80 \pm 19,99$ \\
\hline
\end{tabular}

Grupo (A): Cultura celular irradiada logo após a substituição do MEM contido nas microplacas por MEM suplementado com $5 \%$ de SFB. Grupo (B): Cultura celular irradiada logo após a substituição do MEM contido nas microplacas por PBS. Grupo (C), cultura celular irradiada com o MEM já contido nas microplacas.

A $\mathrm{DL}_{50}$ é a dose de radiação gama que promove a morte celular da metade da população utilizada no ensaio. Para a sua estimativa, foram projetados em gráficos os valores das porcentagens de viabilidade celular, apresentadas na TAB. 17, em função das doses de radiação gama.

As FIG. 19, 20 e 21 ilustram as curvas de viabilidade celular apresentadas pelos grupos (A), (B) e (C), respectivamente. 


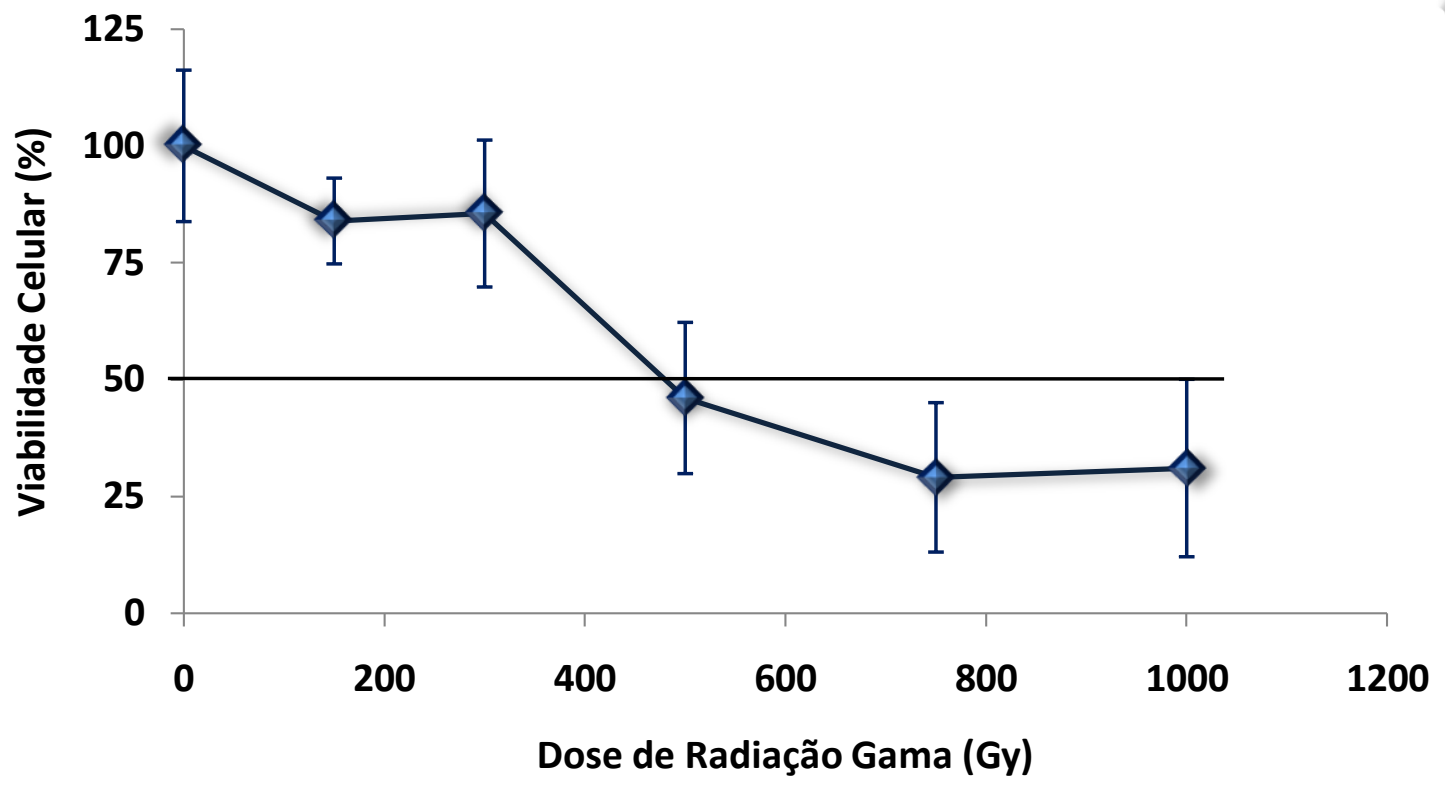

FIGURA 19 - Curva de viabilidade celular obtida no estudo da $\mathrm{DL}_{50}$ da radiação gama referente ao Grupo (A): Irradiação efetuada logo após a substituição do MEM contido nas microplacas por MEM suplementado com $5 \%$ de SFB

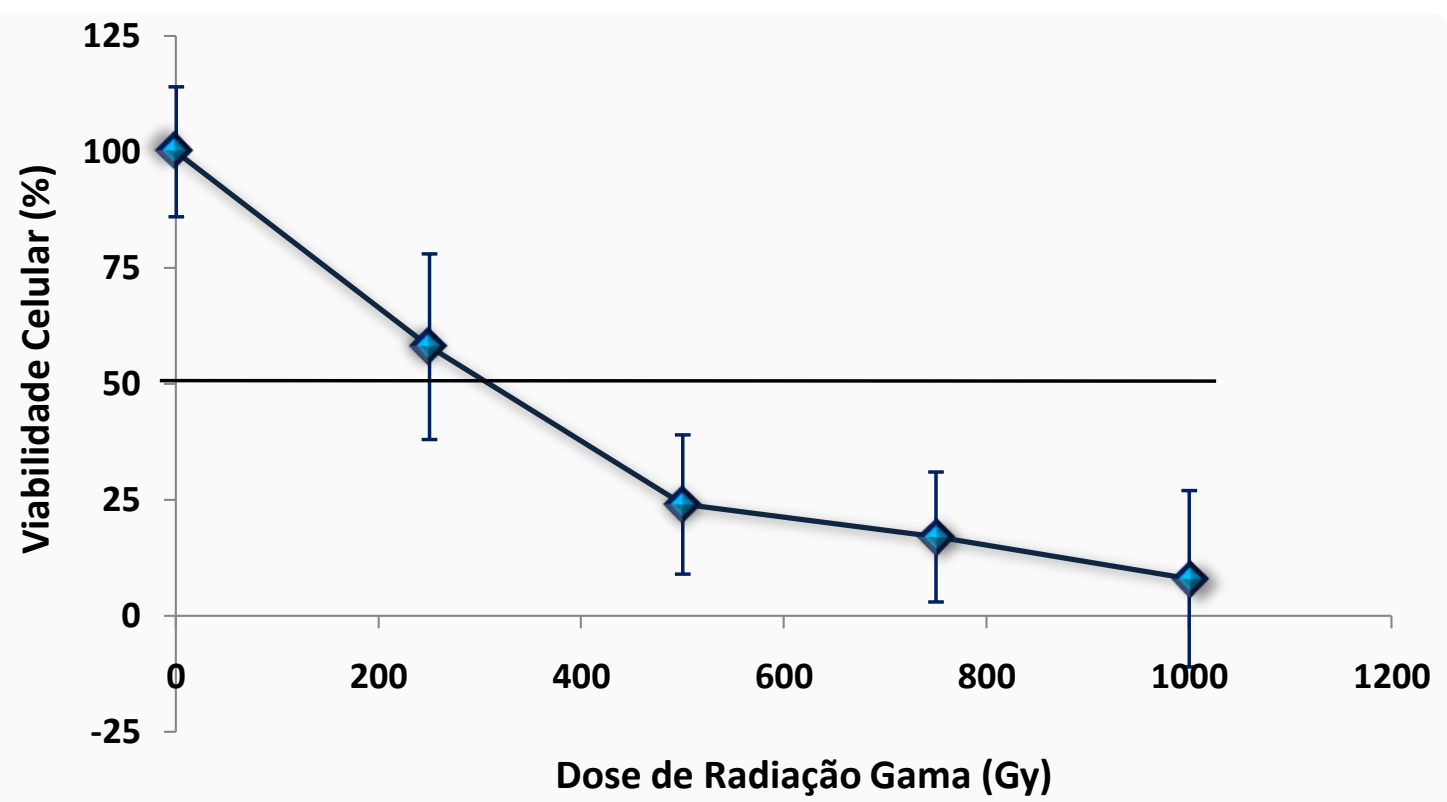

FIGURA 20 - Curva de viabilidade celular obtida no estudo da $\mathrm{DL}_{50}$ da radiação gama referente ao Grupo (B): Irradiação efetuada logo após a substituição do MEM contido nas microplacas por PBS 


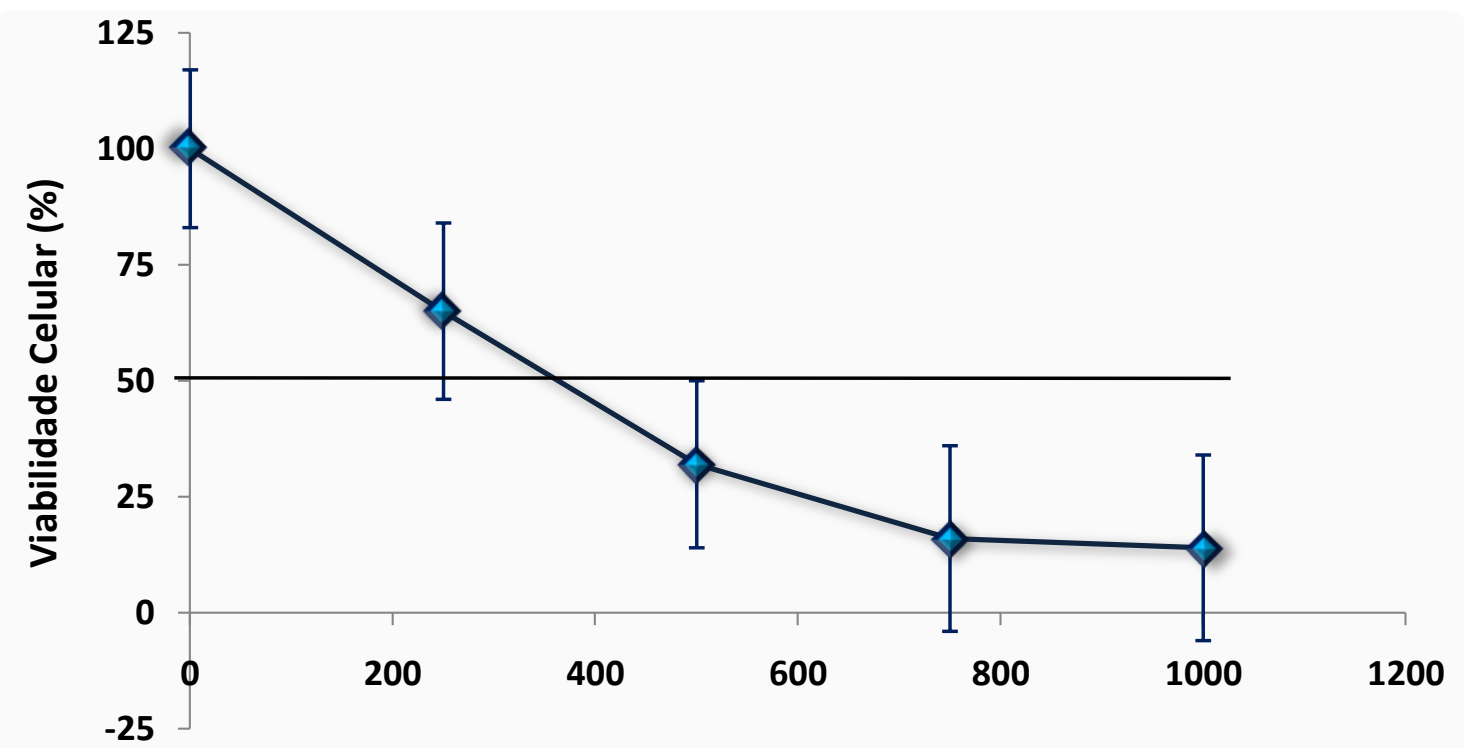

Dose de Radiação Gama (Gy)

FIGURA 21 - Curva de viabilidade celular obtida no estudo da $\mathrm{DL}_{50}$ da radiação gama referente ao Grupo (C): Irradiação das microplacas sem a substituição do MEM prévia a irradiação

A análise gráfica permite estimar a $D_{50}$ na intersecção entre a linha que representa $50 \%$ de viabilidade celular e a curva de sobrevida celular obtida no ensaio. Logo:

- Grupo (A), apresentou uma $\mathrm{DL}_{50}$ de $480 \mathrm{Gy;}$

- Grupo (B), obteve uma $\mathrm{DL}_{50}$ de 278 Gy;

- Grupo (C), mostrou uma $\mathrm{DL}_{50}$ de 354 Gy.

De acordo com as $\mathrm{DL}_{50}$ da radiação gama apresentadas pelos três grupos de estudo, foi verificado que o Grupo (A) necessitou de uma dose de radiação gama maior que os demais grupos para que a metade da sua população celular morresse. Fato este decorrente da interação da radiação gama com 0 MEM fresco suplementado com 5\% de SFB durante o processo de irradiação da cultura celular.

O Grupo (B) apresentou uma $\mathrm{DL}_{50}$ inferior a dos outros dois grupos, devido à presença do PBS durante a irradiação. O PBS proporcionou condições favoráveis à interação da radiação incidente com as células em cultura, 
resultando em danos celulares irreparáveis e consequentemente em uma $\mathrm{DL}_{50}$ inferior à dos outros dois grupos de estudo.

Já no Grupo (C), uma dose de radiação gama intermediária a dos grupos (A) e (B) foi o suficiente para se obter a morte da metade da população celular analisada devido à presença de um meio de cultura celular já metabolizado. Logo, o estudo destes três grupos possibilitou a verificação da influência exercida pelo meio contido na cultura celular durante o processo de irradiação.

Considerando o diferencial metodológico apresentado pelo Grupo (C) como o que mais se assemelha ao procedimento realizado no teste de radioproteção do resveratrol, a estimativa da faixa de dose de radiação gama para a determinação do efeito radioprotetor do composto foi realizada com base na $\mathrm{DL}_{50}$ apresentada por este grupo.

\section{3- Determinação in vitro do efeito radioprotetor do resveratrol}

Após a estimativa do índice de citotoxicidade do resveratrol e da dose letal $50 \%$ da radiação gama, foi efetuada a determinação do efeito radioprotetor do resveratrol em cultura celular.

Com os valores das DO transcritos para o programa "Microsoft Office Excel", foram calculadas as médias das DO, cujos valores representam os efeitos celulares promovidos pela ação da radiação gama na presença e na ausência do resveratrol, assim como as porcentagens de viabilidade celular em relação aos controle de células do ensaio.

O controle de células foi representado pelas microplacas submetidas à radiação gama na ausência do resveratrol, indicando 100\% de sobrevida celular.

As porcentagens de viabilidade celular proporcionadas pelas diferentes doses de radiação gama e concentrações de resveratrol foram calculadas pela equação:

\section{$\%$ Viabilidade Celular $=\left(\mathrm{DO}_{\mathrm{MR}} \times 100\right) / \mathrm{DO}_{\mathrm{CC}}$}

Onde, DOMR: Densidade óptica das microplacas expostas a diferentes concentrações de resveratrol e doses de radiação gama; $\mathrm{DO}_{\mathrm{CC}}$ : Densidade óptica do controle de células do ensaio. 
Inicialmente, os ensaios realizados para a verificação do efeito radioprotetor do resveratrol utilizaram microplacas contendo cultura celular de tecido conectivo de camundongo na mesma densidade de células analisada nos ensaios de $\mathrm{IC}_{50 \%}$ e $\mathrm{DL}_{50}\left(7,0 \times 10^{4}\right.$ células/poço).

Visando a obtenção de uma metodologia adequada a este estudo biológico, os primeiros ensaios de radioproteção do resveratrol foram realizados com alguns diferenciais metodológicos restritos ao processo de distribuição das soluções nos poços das microplacas, ao meio contido na microplaca durante a irradiação e ao processo de irradiação, sendo apresentados em grupos:

- Grupo (A):

- Distribuição das soluções de resveratrol nas microplacas: em triplicata;

- Meio contido na microplaca durante a irradiação: soluções de resveratrol.

- Grupo (B):

- Distribuição das soluções de resveratrol nas microplacas: em triplicata;

- Meio contido na microplaca durante a irradiação: PBS.

- Grupo (C):

- Distribuição das soluções de resveratrol nas microplacas: em triplicata;

- Meio contido na microplaca durante a irradiação: soluções de resveratrol;

- Processo de irradiação das microplacas: individualizado.

- Grupo (D):

- Distribuição das soluções de resveratrol nas microplacas: uma concentração de resveratrol em cada microplaca;

- Meio contido na microplaca durante a irradiação: soluções de resveratrol.

Para verificar a reprodutibilidade das metodologias, foram efetuados, em períodos diferentes, quatro ensaios do Grupo (A), um ensaio do Grupo (B), um ensaio do Grupo (C) e dois ensaios do Grupo (D).

As TAB. 18, 19, 20 e 21 expressam os valores médios das DO obtidos nos ensaios do Grupo (A). As TAB. 22 e 23 mostram os valores dos ensaios dos Grupos (B) e (C), respectivamente. Os valores médios das DO obtidos nos ensaios do Grupo (D) estão registrados nas TAB. 24 e 25. 
TABELA 18 - Médias das DO obtidas no ensaio 1 de radioproteção do resveratrol referente ao Grupo (A)

\begin{tabular}{ccccc}
\hline $\begin{array}{c}\text { Dose de Radiação } \\
\text { Gama (Gy) }\end{array}$ & \multicolumn{4}{l}{ Concentração de Resveratrol $(\boldsymbol{\mu M} / \mathbf{L})$} \\
\cline { 2 - 5 } & 0 & 6,25 & 12,5 & 25 \\
\hline 0 & $0,26 \pm 0,05$ & $0,28 \pm 0,05$ & $0,33 \pm 0,06$ & $0,34 \pm 0,07$ \\
300 & $0,31 \pm 0,04$ & $0,30 \pm 0,05$ & $0,29 \pm 0,04$ & $0,25 \pm 0,03$ \\
700 & $0,29 \pm 0,05$ & $0,31 \pm 0,04$ & $0,33 \pm 0,06$ & $0,28 \pm 0,03$
\end{tabular}

Diferenciais metodológicos do Grupo (A): distribuição em triplicata das soluções de resveratrol nas microplacas; irradiação da cultura celular na presença das soluções de resveratrol. 
TABELA 19 - Médias das DO obtidas no ensaio 2 de radioproteção do resveratrol referente ao Grupo $(\mathrm{A})$

\begin{tabular}{ccccc}
\hline $\begin{array}{c}\text { Dose de Radiação } \\
\text { Gama (Gy) }\end{array}$ & \multicolumn{4}{l}{ Concentração de Resveratrol $(\mu \mathrm{M} / \mathrm{L})$} \\
\cline { 2 - 5 } & 0 & 6,25 & 12,5 & 25 \\
\hline 0 & $0,27 \pm 0,05$ & $0,32 \pm 0,05$ & $0,34 \pm 0,05$ & $0,31 \pm 0,05$ \\
200 & $0,34 \pm 0,06$ & $0,35 \pm 0,07$ & $0,33 \pm 0,03$ & $0,22 \pm 0,04$ \\
400 & $0,37 \pm 0,07$ & $0,40 \pm 0,07$ & $0,43 \pm 0,06$ & $0,19 \pm 0,04$ \\
800 & $0,26 \pm 0,05$ & $0,35 \pm 0,07$ & $0,33 \pm 0,06$ & $0,12 \pm 0,02$ \\
\end{tabular}

Diferenciais metodológicos do Grupo $(\mathrm{A})$ : distribuição em triplicata das soluções de resveratrol nas microplacas; irradiação da cultura celular na presença das soluções de resveratrol.

TABELA 20 - Médias das DO obtidas no ensaio 3 de radioproteção do resveratrol referente ao Grupo (A)

\begin{tabular}{ccccc}
\hline $\begin{array}{c}\text { Dose de Radiação } \\
\text { Gama (Gy) }\end{array}$ & \multicolumn{4}{l}{ Concentração de Resveratrol $(\mu \mathrm{M} / \mathrm{L})$} \\
\cline { 2 - 5 } & 0 & 6,25 & 12,5 & 25 \\
\hline 0 & $0,78 \pm 0,10$ & $0,72 \pm 0,12$ & $0,70 \pm 0,12$ & $0,71 \pm 0,13$ \\
250 & $0,71 \pm 0,12$ & $0,73 \pm 0,11$ & $0,70 \pm 0,08$ & $0,51 \pm 0,08$ \\
500 & $0,59 \pm 0,05$ & $0,57 \pm 0,09$ & $0,56 \pm 0,05$ & $0,33 \pm 0,02$
\end{tabular}

Diferenciais metodológicos do Grupo $(\mathrm{A})$ : distribuição em triplicata das soluções de resveratrol nas microplacas; irradiação da cultura celular na presença das soluções de resveratrol. 
TABELA 21 - Médias das DO obtidas no ensaio 4 de radioproteção do resveratrol referente ao Grupo $(\mathrm{A})$

\begin{tabular}{cccccc}
\hline $\begin{array}{c}\text { Dose de Radiação } \\
\text { Gama (Gy) }\end{array}$ & \multicolumn{5}{c}{ Concentração de Resveratrol $(\mu \mathrm{M} / \mathrm{L})$} \\
\cline { 2 - 6 } & 0 & 6,25 & 12,5 & 25 & 30 \\
\hline 0 & $0,43 \pm 0,07$ & $0,85 \pm 0,06$ & $0,85 \pm 0,06$ & $0,79 \pm 0,09$ & $0,69 \pm 0,10$ \\
250 & $0,60 \pm 0,08$ & $0,85 \pm 0,09$ & $0,79 \pm 0,08$ & $0,58 \pm 0,08$ & $0,34 \pm 0,07$ \\
500 & $0,54 \pm 0,05$ & $0,75 \pm 0,05$ & $0,71 \pm 0,06$ & $0,41 \pm 0,08$ & $0,24 \pm 0,05$
\end{tabular}

Diferenciais metodológicos do Grupo $(\mathrm{A})$ : distribuição em triplicata das soluções de resveratrol nas microplacas; irradiação da cultura celular na presença das soluções de resveratrol.

TABELA 22 - Médias das DO obtidas no ensaio 5 de radioproteção do resveratrol referente ao Grupo (B)

\begin{tabular}{ccccc}
\hline $\begin{array}{c}\text { Dose de Radiação } \\
\text { Gama (Gy) }\end{array}$ & \multicolumn{4}{l}{ Concentração de Resveratrol $(\boldsymbol{\mu M} / \mathbf{L})$} \\
\cline { 2 - 5 } & 0 & 6,25 & 12,5 & 30 \\
\hline 0 & $0,35 \pm 0,05$ & $0,36 \pm 0,07$ & $0,34 \pm 0,06$ & $0,28 \pm 0,04$ \\
200 & $0,32 \pm 0,05$ & $0,32 \pm 0,06$ & $0,32 \pm 0,05$ & $0,21 \pm 0,03$ \\
400 & $0,37 \pm 0,04$ & $0,35 \pm 0,04$ & $0,30 \pm 0,04$ & $0,09 \pm 0,02$ \\
800 & $0,33 \pm 0,05$ & $0,34 \pm 0,04$ & $0,29 \pm 0,03$ & $0,08 \pm 0,01$
\end{tabular}

Diferenciais metodológicos do Grupo(B): distribuição em triplicata das soluções de resveratrol nas microplacas; substituição das soluções de resveratrol por MEM com $5 \%$ de SFB previamente à irradiação. 
TABELA 23 - Médias das DO obtidas no ensaio 6 de radioproteção do resveratrol referente ao Grupo $(\mathrm{C})$

\begin{tabular}{ccccc} 
Dose de Radiação & \multicolumn{4}{l}{ Concentração de Resveratrol $(\mu \mathrm{M} / \mathrm{L})$} \\
\cline { 2 - 5 } Gama (Gy) & 0 & 6,25 & 12,5 & 25 \\
\hline 0 & $0,34 \pm 0,04$ & $0,39 \pm 0,05$ & $0,36 \pm 0,04$ & $0,35 \pm 0,05$ \\
200 & $0,33 \pm 0,05$ & $0,37 \pm 0,07$ & $0,34 \pm 0,05$ & $0,31 \pm 0,05$ \\
400 & $0,36 \pm 0,04$ & $0,40 \pm 0,04$ & $0,40 \pm 0,05$ & $0,31 \pm 0,05$ \\
800 & $0,40 \pm 0,05$ & $0,37 \pm 0,04$ & $0,38 \pm 0,04$ & $0,31 \pm 0,03$
\end{tabular}

Diferenciais metodológicos do Grupo (C): distribuição em triplicata das soluções de resveratrol nas microplacas; irradiação individualizada das microplacas contendo as soluções de resveratrol.

TABELA 24 - Médias das DO obtidas no ensaio 7 de radioproteção do resveratrol referente ao Grupo (D)

\begin{tabular}{ccccc}
\hline $\begin{array}{c}\text { Dose de Radiação } \\
\text { Gama (Gy) }\end{array}$ & \multicolumn{4}{c}{ Concentração de Resveratrol $(\mu \mathrm{M} / \mathrm{L})$} \\
\cline { 2 - 5 } & 0 & 6,25 & 12,5 & 25 \\
\hline 0 & $0,34 \pm 0,04$ & $0,40 \pm 0,05$ & $0,55 \pm 0,06$ & $0,51 \pm 0,04$ \\
200 & $0,41 \pm 0,05$ & $0,45 \pm 0,07$ & $0,50 \pm 0,06$ & $0,36 \pm 0,07$ \\
400 & $0,28 \pm 0,04$ & $0,38 \pm 0,05$ & $0,50 \pm 0,08$ & $0,18 \pm 0,04$
\end{tabular}

Diferenciais metodológicos do Grupo (D): distribuição de uma concentração de resveratrol em cada microplaca; irradiação da cultura celular na presença das soluções de resveratrol. 
TABELA 25 - Médias das DO obtidas no ensaio 8 de radioproteção do resveratrol referente ao Grupo (D)

\begin{tabular}{cccccc}
\hline $\begin{array}{c}\text { Dose de } \\
\text { Radiação Gama }\end{array}$ (Gy) & \multicolumn{5}{c}{ Concentração de Resveratrol $(\boldsymbol{\mu M} / \mathrm{L})$} \\
\cline { 2 - 6 } & 0 & 6,25 & 12,5 & 25 & 30 \\
\hline 0 & $0,43 \pm 0,07$ & $0,62 \pm 0,09$ & $0,58 \pm 0,07$ & $0,57 \pm 0,06$ & $0,54 \pm 0,06$ \\
250 & $0,60 \pm 0,08$ & $0,46 \pm 0,09$ & $0,39 \pm 0,08$ & $0,33 \pm 0,05$ & $0,24 \pm 0,04$ \\
500 & $0,54 \pm 0,05$ & $0,53 \pm 0,06$ & $0,49 \pm 0,06$ & $0,30 \pm 0,06$ & $0,17 \pm 0,02$
\end{tabular}

Diferenciais metodológicos do Grupo (D): distribuição de uma concentração de resveratrol em cada microplaca; irradiação da cultura celular na presença das soluções de resveratrol.

As porcentagens de viabilidade celular foram calculadas utilizando-se os valores médios das DO apresentados pelas microplacas expostas a diferentes doses de radiação gama e concentrações de resveratrol em relação ao controle de células do ensaio.

As TAB. 26, 27, 28 e 29 expressam as médias de viabilidade celular obtidas pelo Grupo (A). As TAB. 30 e 31 mostram os valores referentes aos ensaios dos Grupos (B) e (C), respectivamente. Os valores médios das porcentagens de viabilidade celular obtidos pelo Grupo (D) estão registrados na TAB. 32. 
TABELA 26 - Porcentagens de viabilidade celular obtidas no ensaio 1 de radioproteção do resveratrol referente ao Grupo $(A)$

\begin{tabular}{ccccc}
\hline \multirow{2}{*}{$\begin{array}{c}\text { Dose de } \\
\text { Radiação Gama } \\
(\text { Gy) }\end{array}$} & \multicolumn{4}{l}{ Concentração de Resveratrol $(\mu \mathrm{M} / \mathrm{L})$} \\
\cline { 2 - 5 } & 0 & 6,25 & 12,5 & 25 \\
\hline 0 & $100,00 \pm 19,87$ & $100,00 \pm 19,32$ & $100,00 \pm 19,41$ & $100,00 \pm 19,93$ \\
300 & $118,70 \pm 14,52$ & $107,81 \pm 16,45$ & $86,61 \pm 15,14$ & $72,99 \pm 11,13$ \\
700 & $112,88 \pm 16,07$ & $109,97 \pm 13,50$ & $99,80 \pm 18,89$ & $83,43 \pm 10,11$
\end{tabular}

Diferenciais metodológicos do Grupo (A): distribuição em triplicata das soluções de resveratrol nas microplacas; irradiação da cultura celular na presença das soluções de resveratrol.

TABELA 27 - Porcentagens de viabilidade celular obtidas no ensaio 2 de radioproteção do resveratrol referente ao Grupo (A)

\begin{tabular}{ccccc}
\hline \multirow{2}{*}{$\begin{array}{c}\text { Dose de } \\
\text { Radiação Gama } \\
\text { (Gy) }\end{array}$} & \multicolumn{4}{l}{ Concentração de Resveratrol $(\mu M / L)$} \\
\cline { 2 - 5 } & 0 & 6,25 & 12,5 & 25 \\
\hline 0 & $100,00 \pm 19,18$ & $100,00 \pm 15,90$ & $100,00 \pm 14,62$ & $100,00 \pm 14,84$ \\
200 & $125,43 \pm 18,49$ & $107,42 \pm 19,40$ & $99,71 \pm 7,85$ & $70,68 \pm 16,61$ \\
400 & $133,47 \pm 19,44$ & $124,98 \pm 17,23$ & $129,33 \pm 14,43$ & $62,89 \pm 19,76$ \\
800 & $95,11 \pm 19,42$ & $109,24 \pm 19,89$ & $97,40 \pm 17,62$ & $39,56 \pm 17,86$
\end{tabular}

Diferenciais metodológicos do Grupo (A): distribuição em triplicata das soluções de resveratrol nas microplacas; irradiação da cultura celular na presença das soluções de resveratrol. 
TABELA 28 - Porcentagens de viabilidade celular obtidas no ensaio 3 de radioproteção do resveratrol referente ao Grupo $(A)$

\begin{tabular}{ccccc}
\hline \multirow{2}{*}{$\begin{array}{c}\text { Dose de } \\
\text { Radiação Gama } \\
(\text { Gy) }\end{array}$} & \multicolumn{4}{l}{ Concentração de Resveratrol $(\boldsymbol{\mu M} / \mathrm{L})$} \\
\cline { 2 - 5 } & 0 & 6,25 & 12,5 & 25 \\
\hline 0 & $100,00 \pm 12,45$ & $100,00 \pm 16,08$ & $100,00 \pm 17,44$ & $100,00 \pm 17,79$ \\
250 & $90,87 \pm 16,92$ & $100,17 \pm 15,71$ & $100,67 \pm 10,97$ & $71,41 \pm 15,01$ \\
500 & $74,76 \pm 8,41$ & $78,87 \pm 15,48$ & $79,72 \pm 9,09$ & $46,69 \pm 7,17$
\end{tabular}

Diferenciais metodológicos do Grupo $(\mathrm{A})$ : distribuição em triplicata das soluções de resveratrol nas microplacas; irradiação da cultura celular na presença das soluções de resveratrol.

TABELA 29 - Porcentagens de viabilidade celular obtidas no ensaio 4 de radioproteção do resveratrol referente ao Grupo $(A)$

\begin{tabular}{cccccc}
\hline Dose de & \multicolumn{5}{l}{ Concentração de Resveratrol $(\mu \mathrm{M} / \mathrm{L})$} \\
$\begin{array}{c}\text { Radiação } \\
\text { Gama (Gy) }\end{array}$ & 0 & 6,25 & 12,5 & 25 & 30 \\
\hline 0 & $100,00 \pm 15,49$ & $100,00 \pm 7,48$ & $100,00 \pm 6,68$ & $100,00 \pm 11,87$ & $100,00 \pm 14,97$ \\
250 & $138,25 \pm 13,35$ & $99,14 \pm 10,46$ & $93,11 \pm 10,26$ & $73,22 \pm 14,14$ & $50,09 \pm 19,61$ \\
500 & $125,42 \pm 9,34$ & $88,10 \pm 6,85$ & $83,90 \pm 8,31$ & $51,93 \pm 20,49$ & $34,92 \pm 20,37$
\end{tabular}

Diferenciais metodológicos do Grupo $(\mathrm{A})$ : distribuição em triplicata das soluções de resveratrol nas microplacas; irradiação da cultura celular na presença das soluções de resveratrol. 
TABELA 30 - Porcentagens de viabilidade celular obtidas no ensaio 5 de radioproteção do resveratrol referente ao Grupo (B)

\begin{tabular}{ccccc}
\hline $\begin{array}{c}\text { Dose de } \\
\text { Radiação } \\
\text { Gama (Gy) }\end{array}$ & \multicolumn{4}{l}{ Concentração de Resveratrol $(\mu M / L)$} \\
\cline { 2 - 5 } & 0 & 6,25 & 12,5 & 25 \\
\hline 0 & $100,00 \pm 14,56$ & $100,00 \pm 19,20$ & $100,00 \pm 18,31$ & $100,00 \pm 14,09$ \\
200 & $90,59 \pm 15,55$ & $88,23 \pm 19,12$ & $94,05 \pm 16,70$ & $75,20 \pm 14,24$ \\
400 & $105,98 \pm 11,77$ & $97,35 \pm 12,79$ & $89,01 \pm 12,95$ & $32,11 \pm 18,87$ \\
800 & $93,21 \pm 15,59$ & $94,39 \pm 12,59$ & $84,94 \pm 8,89$ & $29,29 \pm 13,84$ \\
\end{tabular}

Diferenciais metodológicos do Grupo(B): distribuição em triplicata das soluções de resveratrol nas microplacas; substituição das soluções de resveratrol por MEM com $5 \%$ de SFB previamente à irradiação.

TABELA 31 - Porcentagens de viabilidade celular obtidas no ensaio 6 de radioproteção do resveratrol referente ao Grupo (C)

\begin{tabular}{ccccc}
\hline $\begin{array}{c}\text { Dose de } \\
\text { Radiação } \\
\text { Gama (Gy) }\end{array}$ & \multicolumn{4}{c}{ Concentração de Resveratrol $(\boldsymbol{\mu M} / \mathbf{L})$} \\
\cline { 2 - 5 } & 0 & 6,25 & 12,5 & 25 \\
\hline 0 & $100,00 \pm 13,22$ & $100,00 \pm 14,02$ & $100,00 \pm 11,71$ & $100,00 \pm 13,28$ \\
200 & $96,60 \pm 16,19$ & $95,76 \pm 19,71$ & $95,46 \pm 14,79$ & $89,41 \pm 14,68$ \\
400 & $105,90 \pm 11,92$ & $102,57 \pm 10,04$ & $111,01 \pm 11,59$ & $88,53 \pm 17,54$ \\
800 & $117,13 \pm 12,71$ & $95,26 \pm 10,29$ & $104,72 \pm 10,17$ & $89,12 \pm 8,61$ \\
& & & & \\
\hline
\end{tabular}

Diferenciais metodológicos do Grupo (C): distribuição em triplicata das soluções de resveratrol nas microplacas; irradiação individualizada das microplacas contendo as soluções de resveratrol. 
TABELA 32 - Porcentagens de viabilidade celular obtidas no ensaio 7 de radioproteção do resveratrol referente ao Grupo (D)

\begin{tabular}{ccccc}
\hline $\begin{array}{c}\text { Dose de Radiação } \\
\text { Gama (Gy) }\end{array}$ & \multicolumn{4}{c}{ Concentração de Resveratrol $(\boldsymbol{\mu M} / \mathrm{L})$} \\
\cline { 2 - 5 } & 0 & 6,25 & 12,5 & 25 \\
\hline 0 & $100,00 \pm 12,79$ & $100,00 \pm 11,91$ & $100,00 \pm 10,61$ & $100,00 \pm 8,63$ \\
200 & $118,59 \pm 11,54$ & $112,38 \pm 16,55$ & $92,06 \pm 12,34$ & $70,80 \pm 19,56$ \\
400 & $81,04 \pm 15,25$ & $95,09 \pm 13,66$ & $90,91 \pm 16,73$ & $35,01 \pm 20,23$
\end{tabular}

Diferenciais metodológicos do Grupo (D): distribuição de uma concentração de resveratrol em cada microplaca; irradiação da cultura celular na presença das soluções de resveratrol.

TABELA 33 - Porcentagens de viabilidade celular obtidas no ensaio 8 de radioproteção do resveratrol referente ao Grupo (D)

\begin{tabular}{|c|c|c|c|c|c|}
\hline \multirow{2}{*}{$\begin{array}{c}\text { Dose de } \\
\text { Radiação } \\
\text { Gama } \\
\text { (Gy) }\end{array}$} & \multicolumn{5}{|c|}{ Concentração de Resveratrol ( $\mu \mathrm{M} / \mathrm{L})$} \\
\hline & 0 & 6,25 & 12,5 & 25 & 30 \\
\hline 0 & $100,00 \pm 15,49$ & $100,00 \pm 14,29$ & $100,00 \pm 12,58$ & $100,00 \pm 10,06$ & $100,00 \pm 10,53$ \\
\hline 250 & $138,25 \pm 13,35$ & $74,14 \pm 19,21$ & $68,13 \pm 19,55$ & $57,03 \pm 15,76$ & $43,69 \pm 18,88$ \\
\hline 500 & $125,42 \pm 9,34$ & $86,16 \pm 11,98$ & $85,59 \pm 12,41$ & $51,97 \pm 19,88$ & $31,23 \pm 11,15$ \\
\hline
\end{tabular}

Diferenciais metodológicos do Grupo (D): distribuição de uma concentração de resveratrol em cada microplaca; irradiação da cultura celular na presença das soluções de resveratrol.

Os resultados expressos nas TAB. 34 e 35 indicam a média da viabilidade celular calculados para os Grupos (A) e (D), respectivamente. 
TABELA 34 - Médias das porcentagens de viabilidade celular obtidas no estudo do efeito radioprotetor do resveratrol referentes ao Grupo $(A)$

\begin{tabular}{cccccc}
\hline $\begin{array}{c}\text { Dose de } \\
\text { Radiação } \\
\text { Gama }\end{array}$ & \multicolumn{5}{c}{ Concentração de Resveratrol ( $\mu M / L)$} \\
(Gy) & 0 & 6,25 & 12,5 & 25 & 30 \\
\hline 0 & $100,00 \pm 16,75$ & $100,00 \pm 14,70$ & $100,00 \pm 14,54$ & $100,00 \pm 16,11$ & $100,00 \pm 14,97$ \\
200 & $125,43 \pm 18,49$ & $107,42 \pm 19,40$ & $99,71 \pm 7,85$ & $70,68 \pm 16,61$ & $/$ \\
250 & $114,56 \pm 15,13$ & $99,65 \pm 13,08$ & $96,89 \pm 10,62$ & $72,31 \pm 14,57$ & $50,09 \pm 19,61$ \\
300 & $118,70 \pm 14,52$ & $107,81 \pm 16,45$ & $86,61 \pm 15,14$ & $72,99 \pm 11,13$ & $72,99 \pm 11,13$ \\
400 & $133,47 \pm 19,44$ & $124,98 \pm 17,23$ & $129,33 \pm 14,43$ & $62,89 \pm 19,76$ & $/$ \\
500 & $100,09 \pm 8,87$ & $83,49 \pm 11,16$ & $81,81 \pm 8,70$ & $49,31 \pm 13,83$ & $34,92 \pm 20,37$ \\
700 & $112,88 \pm 16,07$ & $109,97 \pm 13,50$ & $99,80 \pm 18,89$ & $83,43 \pm 10,11$ & $/$ \\
800 & $95,11 \pm 19,42$ & $109,24 \pm 19,89$ & $97,40 \pm 17,62$ & $39,56 \pm 17,86$ & $/$ \\
\hline
\end{tabular}

Diferenciais metodológicos do Grupo $(A)$ : distribuição em triplicata das soluções de resveratrol nas microplacas; irradiação da cultura celular na presença das soluções de resveratrol. 
TABELA 35 - Média das porcentagens de viabilidade celular obtidas no estudo do efeito radioprotetor do resveratrol referentes ao Grupo (D)

\begin{tabular}{|c|c|c|c|c|c|}
\hline \multirow{2}{*}{$\begin{array}{c}\text { Dose de } \\
\text { Radiação } \\
\text { Gama } \\
\text { (Gy) }\end{array}$} & \multicolumn{5}{|c|}{ Concentração de Resveratrol ( $\mu \mathrm{M} / \mathrm{L})$} \\
\hline & 0 & 6,25 & 12,5 & 25 & 30 \\
\hline 0 & $100,00 \pm 14,14$ & $100,00 \pm 13,10$ & $100,00 \pm 11,59$ & $100,00 \pm 9,34$ & $100,00 \pm 10,53$ \\
\hline 200 & $118,59 \pm 11,54$ & $112,38 \pm 16,55$ & $92,06 \pm 12,34$ & $70,80 \pm 19,56$ & / \\
\hline 250 & $138,25 \pm 13,35$ & $74,14 \pm 19,21$ & $68,13 \pm 19,55$ & $57,03 \pm 15,76$ & $43,69 \pm 18,88$ \\
\hline 400 & $81,04 \pm 15,25$ & $95,09 \pm 13,66$ & $90,91 \pm 16,73$ & $35,01 \pm 20,23$ & / \\
\hline 500 & $125,42 \pm 9,34$ & $86,16 \pm 11,98$ & $85,59 \pm 12,41$ & $51,97 \pm 19,88$ & $31,23 \pm 11,15$ \\
\hline
\end{tabular}

Diferenciais metodológicos do Grupo (D): distribuição de uma concentração de resveratrol em cada microplaca; irradiação da cultura celular na presença das soluções de resveratrol.

O efeito radioprotetor do resveratrol foi avaliado projetando-se em gráfico os valores da viabilidade celular (\%) em função da concentração de resveratrol $(\mu \mathrm{M} / \mathrm{L})$.

As FIG. 23, 24, 25 e 26 ilustram as curvas de viabilidade celular obtidas com base nos dados apresentados nas TAB. 34, 30, 31 e 35, respectivamente. 


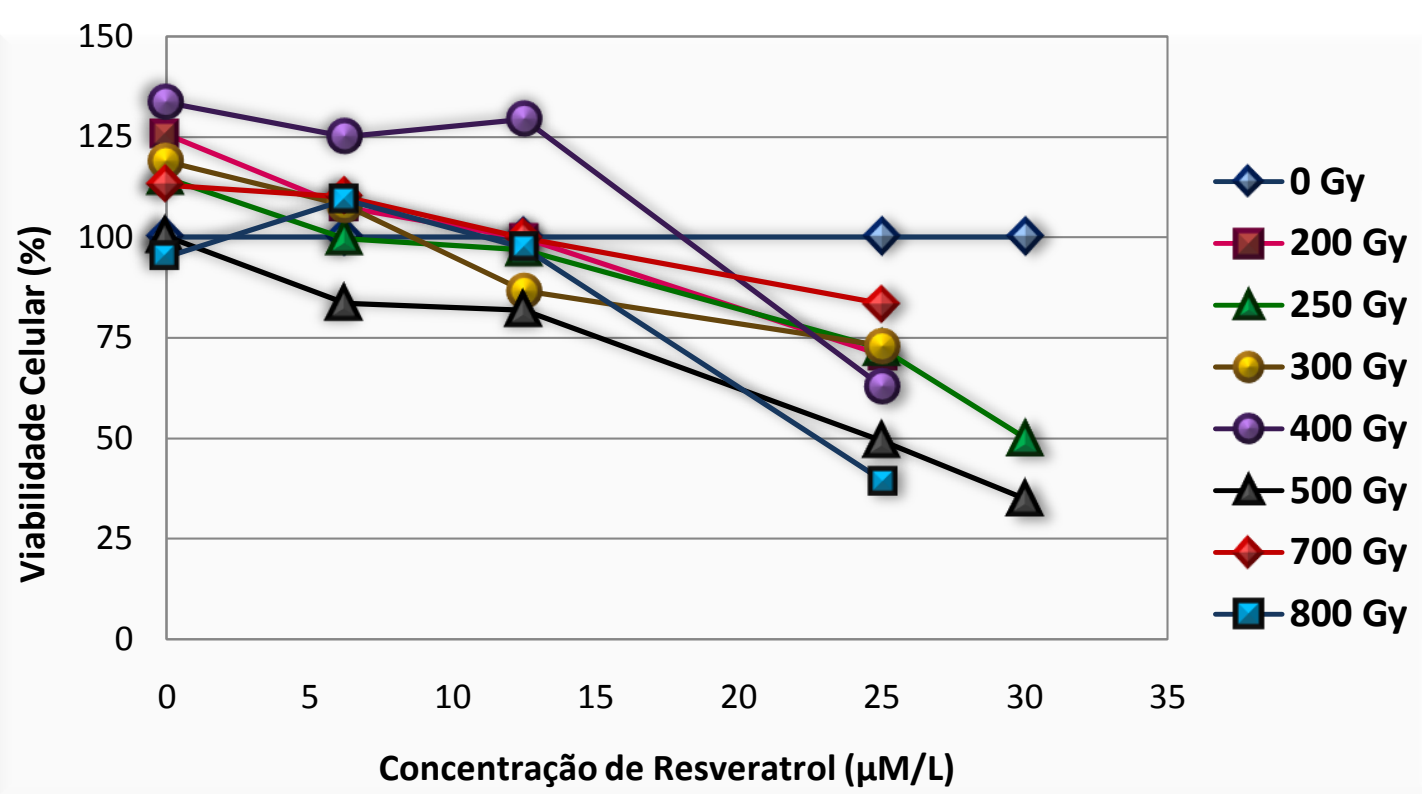

FIGURA 22 - Curvas de viabilidade celular obtidas no estudo do efeito radioprotetor do resveratrol referente ao Grupo $(A)$ : distribuição em triplicata das soluções de resveratrol nas microplacas; irradiação da cultura celular na presença das soluções de resveratrol.

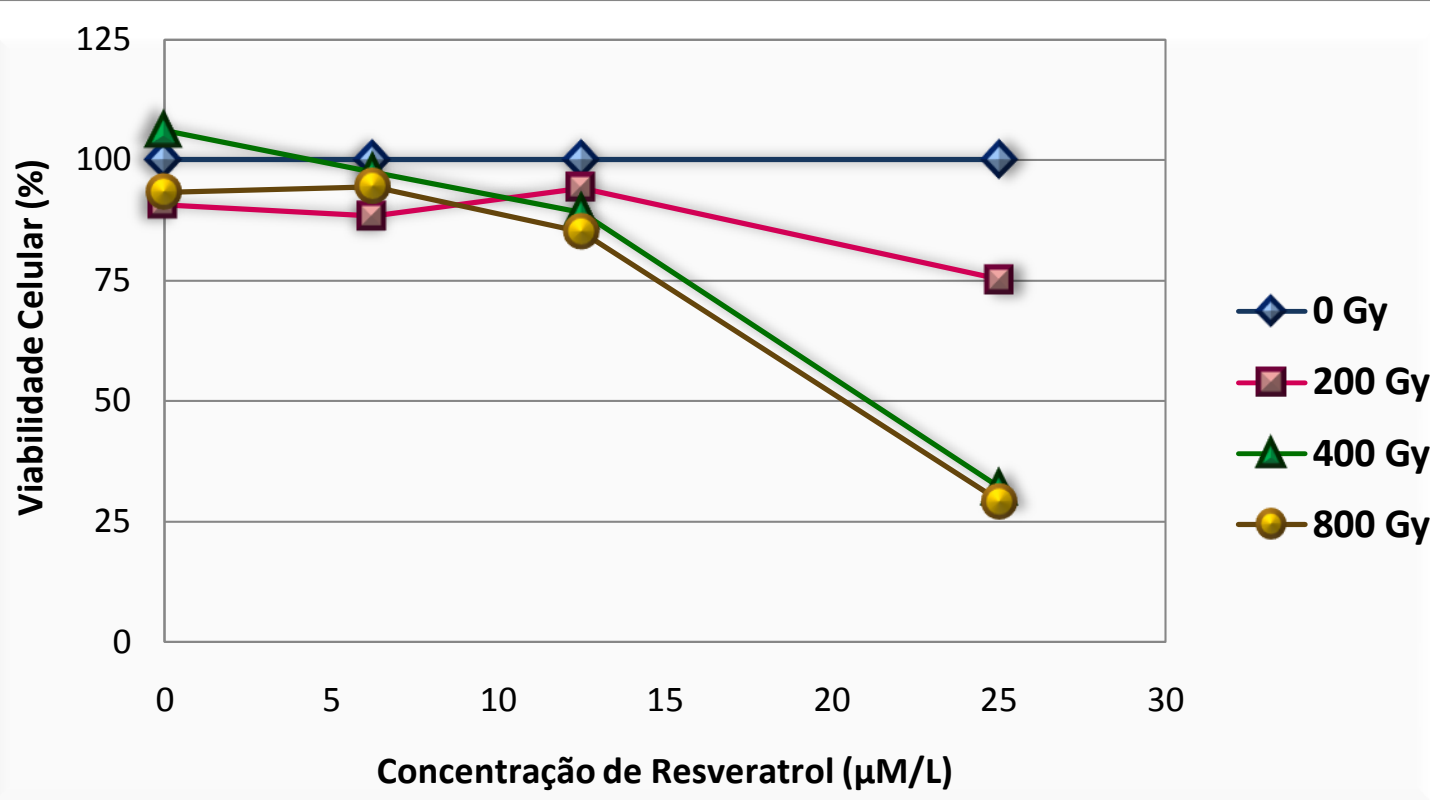

FIGURA 23 - Curvas de viabilidade celular obtidas no estudo do efeito radioprotetor do resveratrol referente ao Grupo (B): distribuição em triplicata das soluções de resveratrol nas microplacas; substituição das soluções de resveratrol por MEM com 5\% de SFB previamente à irradiação. 


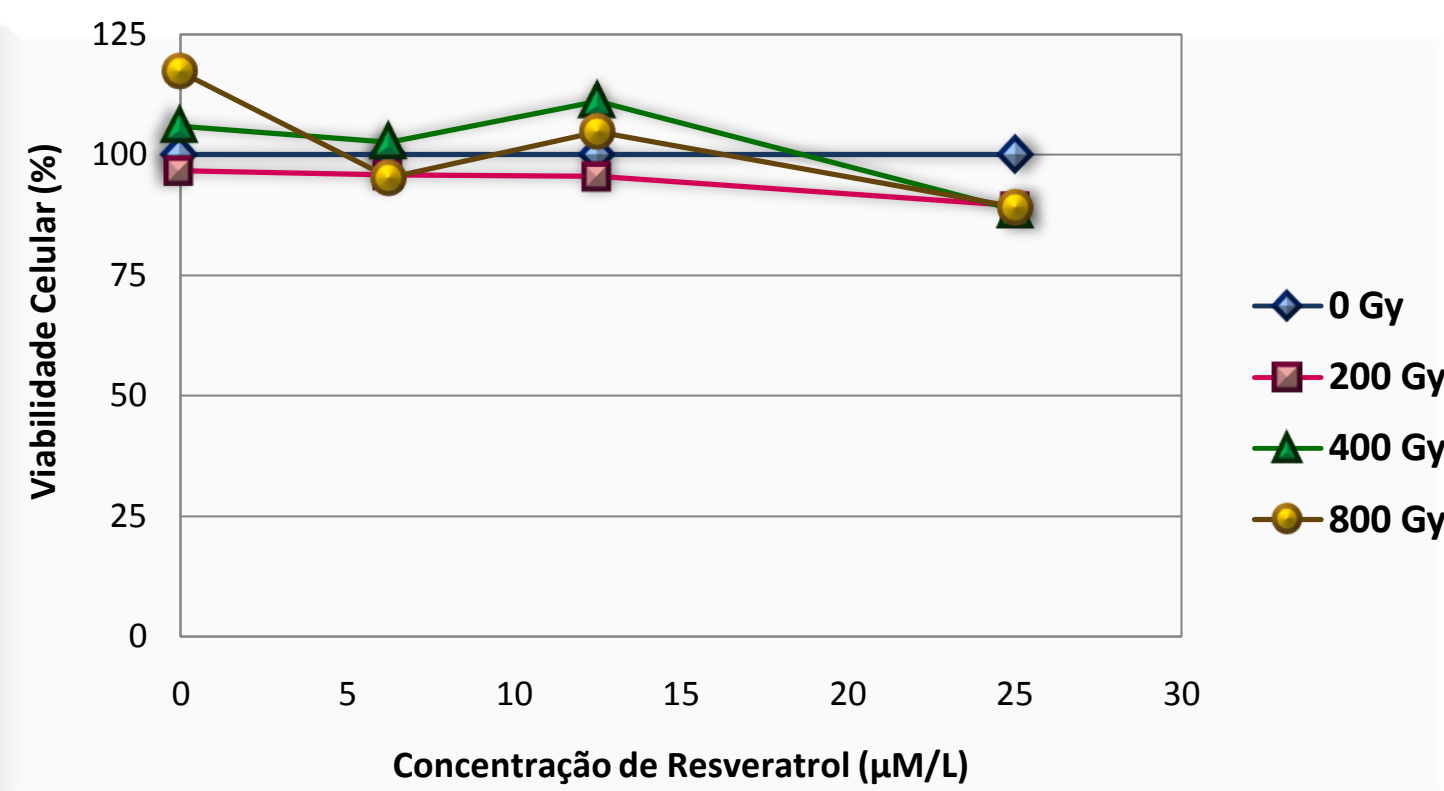

FIGURA 24 - Curvas de viabilidade celular obtidas no estudo do efeito radioprotetor do resveratrol referente ao Grupo $(\mathrm{C})$ : distribuição em triplicata das soluções de resveratrol nas microplacas; irradiação individualizada das microplacas contendo as soluções de resveratrol.

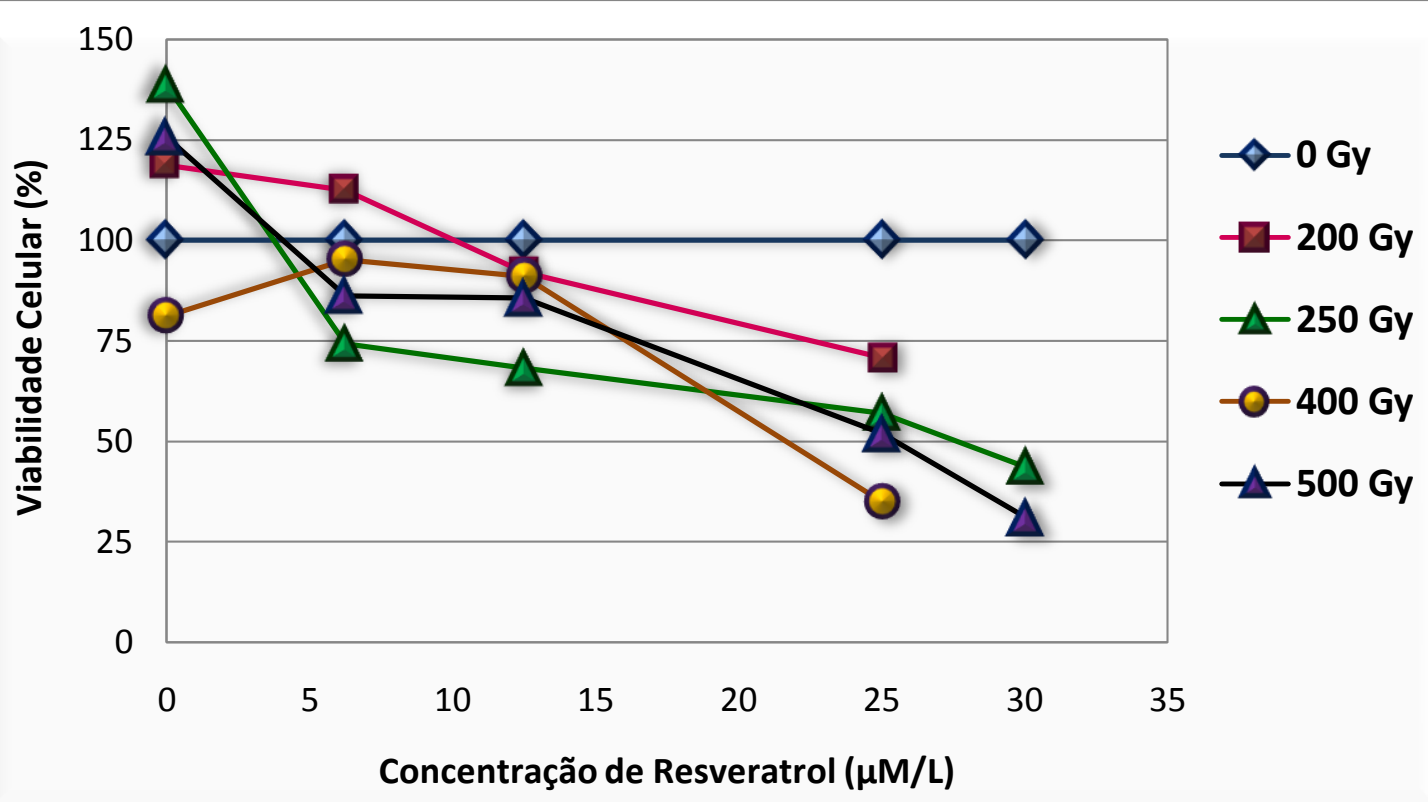

FIGURA 25 - Curvas de viabilidade celular obtidas no estudo do efeito radioprotetor do resveratrol referente ao Grupo (D): distribuição de uma concentração de resveratrol em cada microplaca; irradiação da cultura celular na presença das soluções de resveratrol. 
Pela análise dos dados obtidos pelos grupos de ensaios realizados em cultura de células com densidade de $7,0 \times 10^{4}$ células/poço, foi verificada uma incoerência nos valores de viabilidade celular referentes às microplacas não expostas ao resveratrol $(0 \mu \mathrm{M} / \mathrm{L}$ de resveratrol), os quais permaneceram em cerca de $100 \%$ na faixa de dose de radiação gama analisada. Logo, não foi possível determinar o efeito radioprotetor do resveratrol nesses quatro grupos de ensaios.

Com base nos resultados apresentados pelos ensaios anteriores e visando o aperfeiçoamento da metodologia, novos experimentos foram realizados em cultura celular numa densidade inferior.

A alteração no número de células da cultura celular foi necessária devido ao período de incubação da mesma na presença do resveratrol; período este inexistente no ensaio da $\mathrm{DL}_{50}$ e que possivelmente propiciou um crescimento exacerbado das células, interferindo nos resultados. Assim, um novo ensaio de radioproteção do resveratrol foi efetuado em microplacas com cultura celular numa densidade de 5,0 × $10^{4}$ células/poço, sendo a irradiação das microplacas realizada na presença das soluções de resveratrol.

As TAB. 32 e 33 expressam os valores médios das DO e as porcentagens de viabilidade celular referentes ao ensaio de radioproteção do resveratrol realizado em cultura celular numa densidade de 5,0 × $10^{4}$ células/poço.

TABELA 36 - Médias das DO obtidas no estudo do efeito radioprotetor do resveratrol realizado em cultura de células em uma densidade de $5,0 \times 10^{4}$ células/poço

\begin{tabular}{cccccc}
\hline $\begin{array}{c}\text { Dose de } \\
\text { Radiação } \\
\text { Gama } \\
\text { (Gy) }\end{array}$ & \multicolumn{4}{c}{ Concentração de Resveratrol $(\mu \mathrm{M} / \mathrm{L})$} & \\
\cline { 2 - 6 } & 0 & 6,25 & 12,5 & 25 & 30 \\
\hline 0 & $0,38 \pm 0,08$ & $0,65 \pm 0,07$ & $0,71 \pm 0,06$ & $0,33 \pm 0,06$ & $0,13 \pm 0,02$ \\
300 & $0,36 \pm 0,07$ & $0,50 \pm 0,05$ & $0,49 \pm 0,09$ & $0,08 \pm 0,02$ & $0,03 \pm 0,00$ \\
500 & $0,40 \pm 0,05$ & $0,43 \pm 0,08$ & $0,48 \pm 0,09$ & $0,05 \pm 0,01$ & $0,03 \pm 0,01$ \\
800 & $0,20 \pm 0,04$ & $0,36 \pm 0,05$ & $0,26 \pm 0,05$ & $0,06 \pm 0,01$ & $0,01 \pm 0,00$ \\
& & & & & \\
\hline
\end{tabular}


TABELA 37 - Porcentagens de viabilidade celular obtidas no estudo do efeito radioprotetor do resveratrol realizado em cultura de células em uma densidade de $5,0 \times 10^{4}$ células/poço

\begin{tabular}{cccccc}
\hline $\begin{array}{c}\text { Dose de } \\
\text { Radiação }\end{array}$ & \multicolumn{5}{c}{ Concentração de Resveratrol $(\mu \mathrm{M} / \mathrm{L})$} \\
\cline { 3 - 6 } Gama (Gy) & 0 & 6,25 & 12,5 & 25 & 30 \\
\hline 0 & $100,00 \pm 20,45$ & $100,00 \pm 10,93$ & $100,00 \pm 7,93$ & $100,00 \pm 19,62$ & $100,00 \pm 19,49$ \\
300 & $94,55 \pm 19,22$ & $77,54 \pm 10,46$ & $69,26 \pm 17,50$ & $25,05 \pm 19,81$ & $24,07 \pm 13,22$ \\
500 & $104,22 \pm 11,39$ & $65,81 \pm 18,31$ & $67,41 \pm 18,18$ & $15,33 \pm 18,48$ & $22,84 \pm 19,83$ \\
800 & $51,51 \pm 20,04$ & $55,42 \pm 14,34$ & $37,39 \pm 20,31$ & $18,88 \pm 19,41$ & $10,20 \pm 19,25$ \\
& & & & & \\
\hline
\end{tabular}

Projetando-se os valores das porcentagens de viabilidade celular em função das concentrações de resveratrol utilizadas no ensaio, foi obtido um gráfico que ilustra as curvas de sobrevida celular correspondentes as doses de radiação gama analisadas (FIG. 26). 


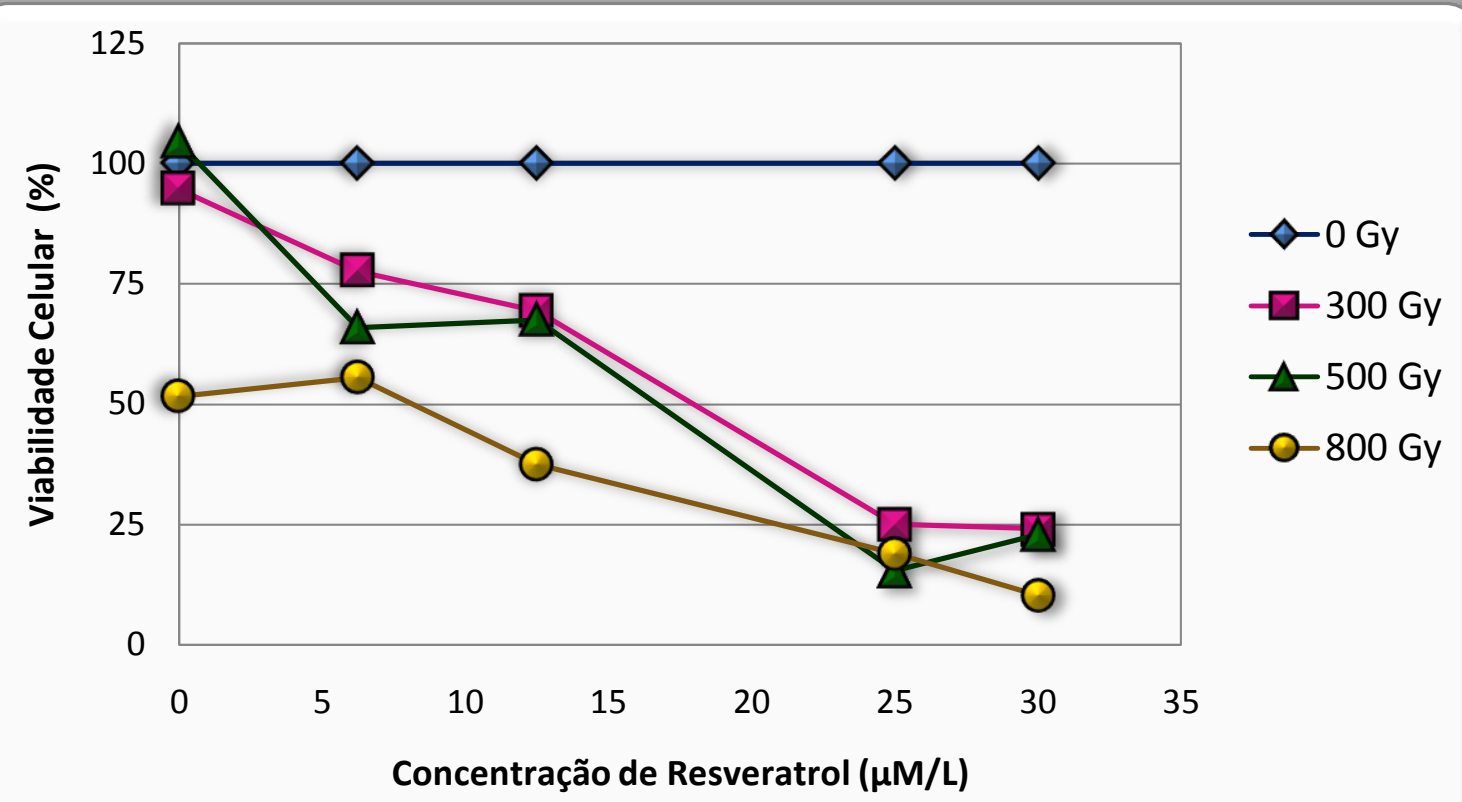

FIGURA 26 - Curvas de viabilidade celular obtidas no estudo do efeito radioprotetor do resveratrol realizado em cultura de células em uma densidade de 5,0 $\times 10^{4}$ células/poço

Pela análise dos dados (TAB. 37 e FIG. 26), pode-se verificar que as porcentagens de viabilidade celular apresentadas pelas microplacas não expostas ao resveratrol foram muito elevadas à faixa de dose de radiação gama a qual foram submetidas.

Numa nova tentativa de eliminar o fator responsável por essa incoerência observada nos resultados dos ensaios anteriores de radioproteção, foram utilizadas culturas celulares em uma densidade de 2,0 $\times 10^{4}$ células/poço, efetuado conforme a metodologia descrita inicialmente neste item.

Nas TAB. 38 e 39 estão registrados os valores médios das $\mathrm{DO}$ e as porcentagens de viabilidade celular obtidas no ensaio de radioproteção do resveratrol realizado em cultura celular com 2,0 x 104 células/poço. 
TABELA 38 - Médias das DO obtidas no estudo do efeito radioprotetor do resveratrol realizado em cultura de células em uma densidade de $2,0 \times 10^{4}$ células/poço

\begin{tabular}{cccccc}
\hline $\begin{array}{c}\text { Dose de } \\
\text { Radiação } \\
\text { Gama }\end{array}$ & \multicolumn{2}{c}{ Concentração de Resveratrol $(\mu \mathrm{M} / \mathrm{L})$} & & \\
\cline { 2 - 6 }$(\mathbf{G y})$ & 0 & 6,25 & 12,5 & 25 & 30 \\
\hline 0 & $0,39 \pm 0,07$ & $0,37 \pm 0,06$ & $0,18 \pm 0,03$ & $0,04 \pm 0,01$ & $0,03 \pm 0,01$ \\
300 & $0,27 \pm 0,03$ & $0,22 \pm 0,03$ & $0,11 \pm 0,02$ & $0,03 \pm 0,01$ & $0,02 \pm 0,00$ \\
500 & $0,18 \pm 0,04$ & $0,18 \pm 0,03$ & $0,08 \pm 0,02$ & $0,03 \pm 0,01$ & $0,02 \pm 0,00$ \\
800 & $0,09 \pm 0,02$ & $0,11 \pm 0,02$ & $0,04 \pm 0,01$ & $0,02 \pm 0,00$ & $0,01 \pm 0,00$
\end{tabular}

TABELA 39 - Porcentagens de viabilidade celular obtidas no estudo do efeito radioprotetor do resveratrol realizado em cultura de células em uma densidade de $2,0 \times 10^{4}$ células/poço

\begin{tabular}{cccccc}
\hline $\begin{array}{c}\text { Dose de } \\
\text { Radiação } \\
\text { Gama }\end{array}$ & \multicolumn{5}{c}{ Concentração de Resveratrol ( $\mu M / L)$} \\
(Gy) & 0 & 6,25 & 12,5 & 25 & 30 \\
\hline 0 & $100,00 \pm 18,29$ & $100,00 \pm 15,32$ & $100,00 \pm 19,13$ & $100,00 \pm 19,94$ & $100,00 \pm 19,86$ \\
300 & $69,41 \pm 12,12$ & $58,08 \pm 13,30$ & $58,94 \pm 19,48$ & $69,59 \pm 19,65$ & $67,32 \pm 15,07$ \\
500 & $46,39 \pm 19,59$ & $48,57 \pm 15,02$ & $41,97 \pm 19,78$ & $66,88 \pm 20,49$ & $64,48 \pm 15,15$ \\
800 & $22,86 \pm 19,60$ & $28,84 \pm 16,52$ & $23,38 \pm 20,26$ & $52,94 \pm 17,72$ & $31,36 \pm 19,80$
\end{tabular}

Os valores de viabilidade celular das microplacas com $0 \mu \mathrm{M} / \mathrm{L}$ de resveratrol obtidos nos ensaios realizados em cultura de células com densidade de 2,0 $\times 10^{4}$ células/poço, expostos na TAB. 39, apresentaram um perfil semelhante ao obtido no ensaio da dose letal $50 \%$, sendo observado um 
decréscimo da porcentagem de viabilidade celular em função do aumento da dose de radiação gama. Diante da coerência dos dados apresentados, a determinação do efeito radioprotetor do resveratrol foi realizada neste ensaio.

Para a análise gráfica dos dados obtidos, foram projetados os valores de viabilidade celular (\%) em função das concentrações do resveratrol $(\mu \mathrm{M} / \mathrm{L})$, apresentada pela FIG. 27.

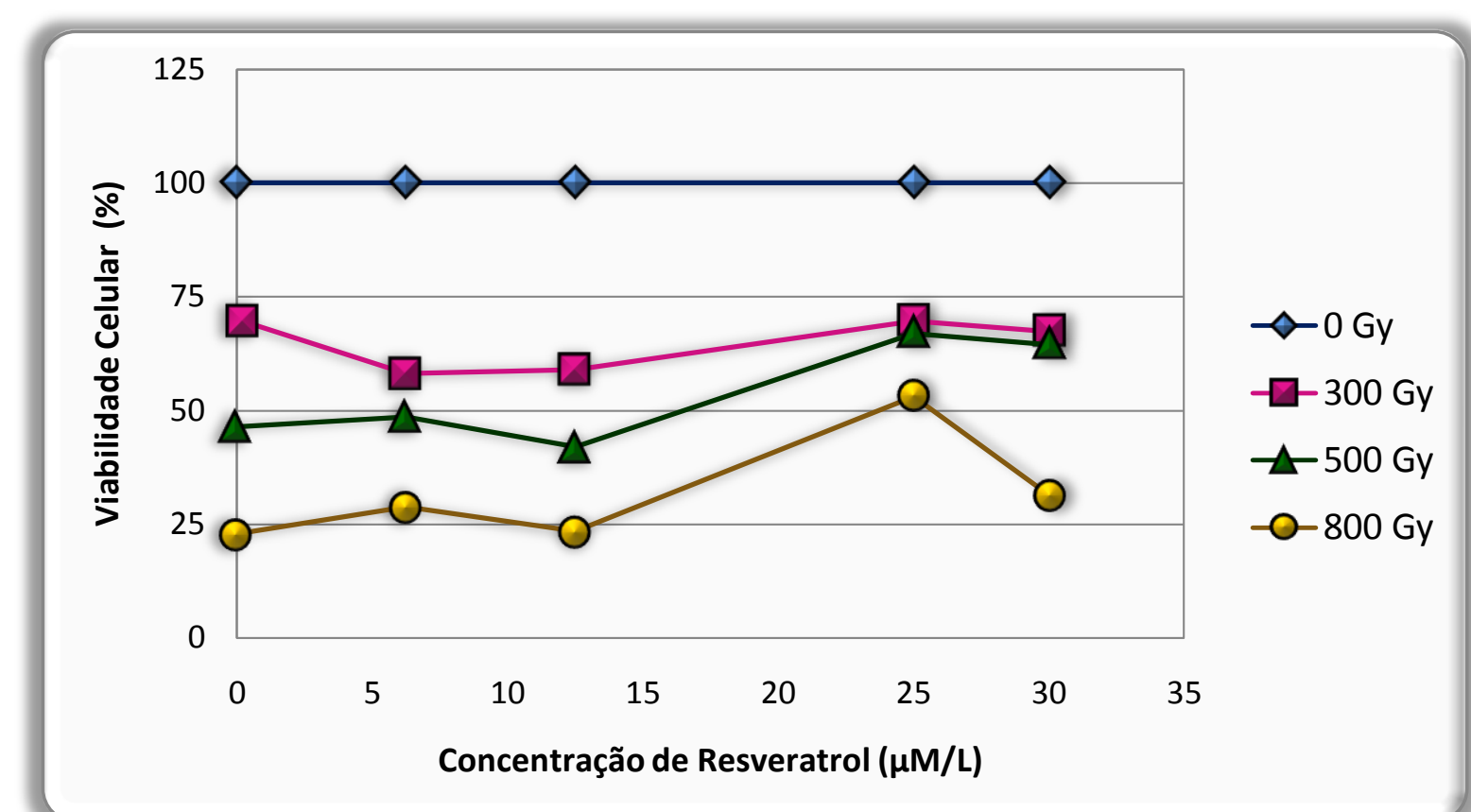

FIGURA 27 - Curvas de viabilidade celular obtidas no estudo do efeito radioprotetor do resveratrol realizado em cultura de células em uma densidade de $2,0 \times 10^{4}$ células/poço

Padronizando-se a viabilidade celular das microplacas submetidas à radiação gama sem o prévio tratamento com o resveratrol em cerca de $100 \%$, observa-se que as células previamente expostas ao resveratrol e submetidas à radiação gama apresentaram um aumento da viabilidade celular em função da concentração de resveratrol, sendo esta tendência mais acentuada entre as concentrações de $12,5 \mu \mathrm{M} / \mathrm{L}$ e $25 \mu \mathrm{M} / \mathrm{L}$.

O efeito radioprotetor evidenciado nesta análise foi recentemente verificado em camundongos tratados com 0 resveratrol e posteriormente submetidos à dose única de radiação gama (3,0 Gy). Neste estudo realizado por 
Carsten et al. (2008) foi constatado uma redução na incidência de aberrações cromossômicas resultantes tanto da interação com a radiação gama como de processos fisiológicos.

Os ensaios in vitro realizados para o estudo do efeito radioprotetor do resveratrol apresentaram vantagens metodológicas referentes à rapidez no período de teste, reprodutibilidade, custo reduzido e principalmente, redução do uso de animais de laboratório. 


\section{CONCLUSÕES}

O efeito radioprotetor exercido pelo resveratrol foi verificado em cultura celular de tecido conectivo de camundongo (NCTC Clone 929 do ATCC) com auxílio dos ensaios in vitro de citotoxicidade do resveratrol e da dose letal $50 \%$ da radiação gama, minimizando o uso de animais de laboratório.

Inicialmente foi realizada uma padronização das metodologias referentes aos ensaios in vitro da dose letal $50 \%$ da radiação gama $\left(\mathrm{DL}_{50}\right)$ e da verificação do efeito radioprotetor do resveratrol, partindo do ensaio de citotoxicidade pelo método de incorporação do corante vermelho neutro. A densidade da cultura celular adequada aos ensaios de citotoxicidade do resveratrol e da dose letal $50 \%$ da radiação gama foi de $7,0 \times 10^{4}$ células/poço. Já a densidade celular de $2,0 \times 10^{4}$ células/poço possibilitou a realização do teste de radioproteção do resveratrol. A discrepância nos valores das densidades celular utilizadas nos testes biológicos foi decorrente do período adicional de incubação da cultura celular necessária ao teste de radioproteção do resveratrol.

$\mathrm{O}$ índice de citotoxicidade $\left(\mathrm{IC}_{50 \%}\right)$ do resveratrol apresentou uma concentração de aproximadamente $50 \mu \mathrm{M} / \mathrm{L}$, concentração esta necessária para o resveratrol induzir $50 \%$ de morte da população celular em estudo.

A dose letal $50 \%\left(\mathrm{DL}_{50}\right)$, dose de radiação gama que induz $50 \%$ de morte celular da população analisada, foi de aproximadamente $354 \mathrm{~Gy}$, sendo este valor variável de acordo com o meio contido na cultura celular durante o processo de irradiação.

O estudo in vitro do efeito radioprotetor do resveratrol evidenciou uma maior resistência das células em cultura aos efeitos danosos oriundos da interação da radiação gama, quando irradiadas na presença do resveratrol. $O$ potencial radioprotetor do resveratrol foi mais acentuado nas concentrações entre $12,5 \mu \mathrm{M} / \mathrm{L}$ e $25,0 \mu \mathrm{M} / \mathrm{L}$.

Este trabalho proporcionou dados inéditos sobre 0 potencial radioprotetor do resveratrol in vitro e evidenciou a sua baixa toxicidade em cultura celular de tecido conectivo de camundongo. Os dados obtidos ao longo deste trabalho contribuem para o desenvolvimento de futuros estudos in vivo, ampliando 
o conhecimento das propriedades biológicas do resveratrol em processos fisiológicos e patológicos.

Estudos sobre o potencial radioprotetor do resveratrol associados a sua reconhecida capacidade de prevenir a carcinogênese contribuem para a avaliação do potencial clínico do resveratrol visando reduzir ou inibir os efeitos nocivos da radiação para a população de risco. 


\section{REFERÊNCIAS BIBLIOGRÁFICAS}

1 ADRIAN, M.; JEANDET, P.; BESSIS, R.; JOUBERT, J.M. Induction of phytoalexin (resveratrol) synthesis in grapevine leaves treated with aluminum chloride (AICI). J. Agric. Food Chem., v. 44, p. 1979-1981, 1996.

2 ADRIAN, M.; JEANDET, P.; DOUILLET-BREUIL, A.C.; TESSON, L.; BESSIS, R. Stilbene content of mature Vitis vinifera berries in response to UV-C elicitation. J. Agric. Food Chem., v. 48, p. 6103-6105, 2000.

3 ASENSI, M.; MEDINA, I.; ORTEGA, A.; CARRETERO, J.; BAÑO, M.C.; OBRADOR, E.; ESTRELA, J.M. Inhibition of cancer growth by resveratrol is related to its low bioavailability. Free Radic. Biol. Med., v. 33, p. 387-398, 2002.

4 ATTEN, M.J.; ATTAR, B.M.; MILSON, T.; HOLIAN, O. Resveratrol-induced inactivation of human gastric adenocarcinoma cells through a protein kinase C-mediated mechanism. Biochem. Pharmacol., v. 62, p. 1423-1432, 2001.

5 BÉLIVEAU, R.; GINGRAS, D. Os alimentos contra o câncer: a prevenção e o tratamento do câncer pela alimentação. Petrópolis: Editora Vozes, 2007.

6 BISHAYEE, A.; DHIR, N. Resveratrol-mediated chemoprevention of diethylnitrosamine-initiated hepatocarcinogenesis: inhibition of cell proliferation and induction of apoptosis. Chem. Biol. Interact., v. 179, p. 131-144, 2009.

7 CARERI, M.; CORRADINI, C.; ELVIRI, L.; NICOLETTI, I.; ZAGNONI, I. Direct HPLC analysis of quercetin and trans-resveratrol in red wine, grape, and winemaking byproducts. J. Agric. Food Chem., v. 51, p. 5226-5231, 2003.

8 CARSTEN, R.E.; BACHAND, A.M.; BAILEY, S.M.; ULLRICH, R.L. Resveratrol reduces radiation-induced chromosome aberration frequencies in mouse bone marrow cells. Radiat. Res., v. 169, p. 633-638, 2008.

9 CELOTTI, E.; FERRARINI, R.; ZIRONI, R.; CONTE, L.S. Resveratrol content of some wines obtained from dried Valpolicella grapes: Recioto and Amarone. J. Chromatogr. A, v. 730, p. 47-52, 1996. 
10 CHAVES, A.A.; JOSHI, M.S.; COYLE, C.M.; BRADY, J.E.; DECH, S.J.; SCHANBACHER, B.L.; BALIGA, R.; BASURAY, A.; BAUER, J.A.

Vasoprotective endothelial effects of a standardized grape product in humans. Vascul. Pharmacol., v. 50, p. 20-26, 2009.

11 CHEN, X.; HE, H.; WANG, G.; YANG, B.; REN, W.; MA, L.; YU, Q. Stereospecific determination of cis- and trans-resveratrol in rat plasma by HPLC: application to pharmacokinetic studies. Biomed. Chromatogr., v. 21, p. 257-265, 2007.

12 CHOI, S.Y.; KIM, S.; SON, D. ; LEE, P. ; LEE, J. ; LEE, S. ; KIM, D.S. ; PARK, Y. ; KIM, S.Y. Protective effect of (4-Methoxybenzylidene)-(3methoxynophenyl)amine against neuronal cell death induced by oxygen and glucose deprivation in rat organotypic hippocampal slice culture. Biol. Pharm. Bull., v. 30, p. 189-192, 2007.

13 CHUKWUMAH, Y.C.; WALKER, L.T.; VERGHESE, M.; OGUTU, S. Effect of frequency and duration of ultrasonication on the extraction efficiency of selected isoflavones and trans-resveratrol from peanuts (Arachis hypogaea). Ultrason. Sonochem., v. 16, p. 293-299, 2009.

14 DOCHERTY, J.J.; FU, M.M.H.; STIFFLER, B.S.; LIMPEROS, R.J.; POKABLA, C.M.; DE LUCIA, A.L. Resveratrol inhibition of herpes simplex virus replication. Antiviral Res., v. 43, p. 135-145, 1999.

15 DOCHERTY, J.J.; SMITH, J.S.; FU, M.M.; STONER, T.; BOOTH, T. Effect of topically applied resveratrol on cutaneous herpes simplex virus infections in hairless mice. Antiviral Res., v. 61, p. 19-26, 2004.

16 DOUILLET-BREUIL, A.C.; JEANDET, P.; ADRIAN, M.; BESSIS, R. Changes in the phytoalexin content of various Vitis Spp. in response to ultraviolet $\mathrm{C}$ elicitation. J. Agric. Food Chem., v. 47, p. 4456-4461, 1999.

17 DOWD, S.B.; TILSON, E.R. Practical radiation protection and applied radiobiology. 2.ed. Philadelphia, P.A.: Saunders Company, 1999.

18 DU, F.Y.; XIAO, X.H.; LI, G.K. Application of ionic liquids in the microwaveassisted extraction of trans-resveratrol from Rhizma Polygoni Cuspidati. J. Chromatogr. A, v. 1140, p. 56-62, 2007.

19 EL-MOWAFY, A.M.; ALKHALAF, M. Resveratrol activates adenylyl-cyclase in human breast cancer cells: a novel, estrogen receptor-independent cytostatic mechanism. Carcinogenesis, v. 24, p. 869-873, 2003. 
20 FABIÃO, C. O vinho na Lusitânia: reflexões em torno de um problema arqueológico. Revista Portuguesa de Arqueologia, v. 1, p. 169-198, 1998.

21 FAJARDO, L.F.; BERTHRONG, M.; ANDERSON, R.E. Radiation pathology. New York, N.Y.: Oxford, 2001.

22 FRÉMONT, L. Minireview: Biological effects of resveratrol. Life Sci., v. 66, p. 663-673, 2000.

23 GEHM, B.D.; MC ANDREWS, J.M.; CHIEN, P.Y.; JAMESON, J.L. Resveratrol, a polyphenolic compound found in grapes and wine, is an agonist for the estrogen receptor. Proc. NatI. Acad. Sci. U.S.A., v. 94, p. 14138-14143, 1997.

24 GETOFF, N. Radiation-induced degradation of water pollutants-state of the art. Radiat. Phys. Chem., v. 47, p. 581-593, 1996.

25 GOLDBERG, D.M.; HAHN, S.E.; PARKES, J.G. Beyond alcohol: beverage consumption and cardiovascular mortality. Clin. Chim. Acta, v. 237, p. 155187, 1995a.

26 GOLDBERG, D.M.; KARUMANCHIRI, A.; NG, E.; YAN, J.; DIAMANDIS, E.P.; SOLEAS, G.J. Direct gas chromatographic - mass spectrometric method to assay cis-resveratrol in wines: preliminary survey of its concentration in commercial wines. J. Agric. Food Chem., v. 43, p. 1245-1250, $1995 \mathrm{~b}$.

27 GOLDBERG, D.M.; YAN, J.; NG, E.; DIAMANDIS, E.P.; KARUMANCHIRI, A.; SOLEAS, G.; WATERHOUSE, A.L. Direct injection gas chromatographic mass spectrometric assay for trans-resveratrol. Anal. Chem., v. 66, p. 3959-3963, 1994.

28 GOLKAR, L.; DING, X.Z.; UJIKI, M.B.; SALABAT, M.R.; KELLY, D.L.; SCHOLTENS, D.; FOUGHT, A.J.; BENTREM, D.J.; TALAMONTI, M.S.; BELL, R.H.; ADRIAN, T.E. Resveratrol inhibits pancreatic cancer cell proliferation through transcription induction of macrophage inhibitory cytokine-1. J. Surg. Res., v., 138, p. 163-169, 2007.

29 HATHWAY, D.E.; SEAKINS, J.W.T. Hydroxystilbenes of Eucalyptus wandoo. Bioch., v. 72, p. 369-374, 1959.

30 HEREDIA, A.; DAVIS, C.; REDFIELD, R. Synergistic inhibition of HIV-1 in activated and resting peripheral blood mononuclear cells, monocyte-derived macrophages, and selected drug-resistant isolates with nucleoside analogues combined with a natural product, resveratrol. J. Acquir. Immune Defic. Syndr., v. 25, p. 246-255, 2000. 
31 INTERNATIONAL ORGANIZATION FOR STANDARDIZATION. Biological evaluation of medical devices, part 5, tests for cytotoxicity: in vitro methods, 1999. (ISO 10993-5).

32 JANG, M.; CAI, L.; UDEANI, G.O.; SLOWING, K.V.; THOMAS, C.F.; BEECHER, C.W.W.; FONG, H.H.S.; FARNSWORTH, N.R.; KINGHORN, A.D.; MEHTA, R.G.; MOON, R.C.; PEZZUTO, J.M. Cancer chemopreventive activity of resveratrol, a natural product derived from grapes. Science, v. 275, p. 218220, 1997.

33 JANNIN, B.; MENZEL, M.; BERLOT, J.P.; DELMAS, D.; LANÇON, A.; LATRUFFE, N. Transport of resveratrol, a cancer chemopreventive agent, to cellular targets: plasmatic protein binding and cell uptake. Biochem. Pharmacol., v.68, p. 1113-1118, 2004.

34 JEANDET, P.; DOUILLET-BREUIL, A.C.; BESSIS, R.; DEBORD, S.; SBAGHI, M.; ADRIAN, M. Phytoalexins from the Vitaceae: biosynthesis, phytoalexin gene expression in transgenic plants, antifungal activity, and metabolism. $J$. Agric. Food Chem., v. 50, p. 2731-2741, 2002.

35 LEIRO, J.; ÁlVAREZ, E.; ARRANZ, J.A.; LAGUNA, R.; URIARTE, E.; ORALLO, F. Effects of cis-resveratrol on inflammatory murine macrophages: antioxidant activity and down-regulation of inflammatory genes. J. Leukoc. Biol., v. 75, p. 1156-1165, 2004.

36 LEONARD, S.S.; XIA, C.; JIANG, B.H.; STINEFELT, B.; KLANDORF, H.; HARRIS, G.K.; SHI, X. Resveratrol scavenges reactive oxygen species and effects radical-induced cellular responses. Biochem. Biophys. Res.

Commun., v. 309, p. 1017-1026, 2003.

37 LIMA, M.T.R.; WAFFO-TÉGUO, P.; TEISSEDRE, P.L.; PUJOLAS, A.; VERCAUTEREN, J.; CABANIS, J.C.; MÉRILLON, J.M. Determination of stilbenes (trans-astringin, cis- and trans-piceid, and cis- and trans-resveratrol) in Portuguese wines. J. Agric. Food Chem., v. 47, p. 2666-2670, 1999.

38 LIN, H.Y.; SHIH, A.; DAVIS, F.B.; TANG, H.Y.; MARTINO, L.J.; BENNETT, J.A.; DAVIS, P.J. Resveratrol induced serine phosphorylation of p53 causes apoptosis in a mutant p53 prostate cancer cell line. J. Urol., v. 168, p. 748755, 2002.

39 MAHADY, G.B.; PENDLAND, S.L.; CHADWICK, L.R. Resveratrol and red wine extracts inhibit the growth of $C a g A+$ strains of Helicobacter pylori in vitro. Am. J. Gastroenterol., v. 98, p. 1440-1441, 2003.

40 METTLER JUNIOR, F.A.; UPTON, A.C. Medical effects of ionizing radiation. 2.ed. Philadelphia, P.A.: Saunders Company, 1995. 
41 MILOSO, M.; BERTELLI, A.A.E.; NICOLINI, G.; TREDICI, G.; Resveratrolinduced activation of the mitogen-activated protein kinases, ERK1 and ERK2, in human neuroblastoma SH-SY5Y cells. Neurosci. Lett., v. 264, p. 141-144, 1999.

42 NADERALI, E.K. Obesity and cardiovascular dysfunction: a role for resveratrol? Obes. Res. Clin. Pract., v. 3 p. 45-52, 2009.

43 OLAS, B.; WACHOWICZ, B.; SALUK-JUSZCZAK, J.; ZIELINSKI, T. Effect of resveratrol, a natural polyphenolic compound, on platelet activation induced by endotoxin or thrombin. Thromb. Res., v. 107, p. 141-145, 2002.

44 OPIPARI JUNIOR, A.W..; TAN, L.; BOITANO, A.E.; SORENSON, D.R.; AURORA, A.; LIU, J.R. Resveratrol-induced autophagocytosis in ovarian cancer cells. Cancer Res., v. 64, p. 696-703, 2004.

45 PAN, Q.H.; WANG, L.; LI, J.M. Amounts and subcellular localization of stilbene synthase in response of grape berries to UV irradiation. Plant Sci., v. 176, p. 360-366, 2009.

46 PERVAIZ, S. Chemotherapeutic potential of the chemopreventive phytoalexin resveratrol. Drug Resist. Updat., v. 7, p. 333-344, 2004.

47 PEZET, R.; GINDRO, K.; VIRET, O.; SPRING, J.L. Glycosylation and oxidative dimerization of resveratrol are respectively associated to sensitivity and resistance of grapevine cultivars to downy mildew. Physiol. Mol. Plant Pathol., v. 65, p. 297-303, 2004.

48 PICKELEMAN, J. A glass a day keeps the doctor. Am. Surg., v. 56, p. 395397, 1990.

49 ROGERO, S.O.; LUGÃO, A.B.; IKEDA, T.I.; CRUZ, A.S. Teste in vitro de citotoxicidade: estudo comparativo entre duas metodologias. Mat. Res., v. 6, p. 317-329, 2003.

50 ROMERO-PÉREZ, A.I.; LAMUELA-RAVENTÓS, R.M.; ANDRÉS-LACUEVA, C.; LA TORRE-BORONAT, M.C. Method for the quantitative extraction of resveratrol and piceid isomers in grape berry skins. Effect of powdery mildew on the stilbene content. J. Agric. Food Chem., v. 49, p. 210-215, 2001.

51 ROMERO-PÉREZ, A.I.; LAMUELA-RAVENTÓS, R.M.; WATERHOUSE, A.L.; LA TORRE-BORONAT, M.C. Levels of cis- and trans-resveratrol and their glucosides in white and rosé Vitis vinifera wines from Spain. J. Agric. Food Chem., v. 44, p. 2124-2128, 1996. 
52 SAUTTER, C.K.; DENARDIN, S.; ALVES, A.O.; MALLMANN, C.A.; PENNA, N.G.; HECKTHEUER, L.H. Determinação de resveratrol em sucos de uva no Brasil. Ciênc. Tecnol. Aliment., v. 25, p. 437-442, 2005.

53 SCHÖPPNER, A.; KINDL, H. Purification and properties of a stilbene synthase from induced cell suspension cultures of peanut. J. Biol. Chem., v. 259, p. 6806-6811, 1984.

54 SCHRÖDER, G.; BROWN, J.W.S.; SCHRÖDER, J. Molecular analysis of resveratrol synthase cDNA, genomic clones and relationship with chalcone synthase. Eur. J. Biochem., v. 172, p. 161-169, 1988.

55 SGAMBATO, A.; ARDITO, R.; FARAGLIA, B.; BONINSEGNA, A.; WOLF, F.I.; CITTADINI, A. Resveratrol, a natural phenolic compound, inhibits cell proliferation and prevents oxidative DNA damage. Mutat. Res., v. 496, p. 171180, 2001.

56 SOLEAS, G.J.; DIAMANDIS, E.P.; GOLDBERG, D.M. Resveratrol: a molecule whose time has come? And gone? Clin. Biochem., v. 30, p. 91-113, 1997.

57 SOUTO, A.A.; CARNEIRO, M.C.; SEFERIN, M.; SENNA, M.J.H.; CONZ, A.; GOBBI, K. Determination of trans-resveratrol concentrations in brazilian red wines by HPLC. J. Food Compost. Anal., v. 14, p. 441-445, 2001.

58 SUN, A.Y.; SIMONYI, A.; SUN, G.Y. The "french paradox" and beyond: neuroprotective effects of polyphenols. Free Radic. Biol. Med., v. 32, p. 314318, 2002.

59 TRELA, B.C.; WATERHOUSE, A.L. Resveratrol: isomeric molar absorptivities and stability. J. Agric. Food Chem., v. 44, p. 1253-1257, 1996.

60 VAN ETTEN, H.D.; MANSFIELD, J.W.; BAILEY, J.A.; FARMER, E.E. Two classes of plant antibiotics: phytoalexins versus "phytoanticipins". Plant Cell, v. 6 , p. 1191-1192, 1994.

61 VINGTDEUX, V.; DRESES-WERRINGLOER, U.; ZHAO, H.; DAVIES, P.; MARAMBAUD, P. Review: Therapeutic potential of resveratrol in Alzheimer's disease. BMC Neurosci., v. 9, suppl. 2-S6, 2008.

62 VITRAC, X.; BORNET, A.; VANDERLINDE, R.; VALLS, J.; RICHARD, T.; DELAUNAY, J.C.; MÉRILLON, J.M.; TEISSÉDRE, P.L. Determination of stilbenes $(\delta$-viniferin, trans-astringin, trans-piceid, cis- and trans-resveratrol, $\epsilon$ viniferin) in brazilian wines. J. Agric. Food Chem., v. 53, p. 5664-5669, 2005. 
63 VITRAC, X.; DESMOULIÈRE, A.; BROUILLAUD, B.; KRISA, S. ; DEFFIEUX, G. ; BARTHE, N. ; ROSENBAUM, J. ; MÉRILLON, J.M. Distribution of $\left[{ }^{14} \mathrm{C}\right]-$ trans-resveratrol, a cancer chemopreventive polyphenol, in mouse tissues after oral administration. Life Sci., v. 72, p. 2219-2233, 2003.

64 WALLE, T.; HSIEH, F.; DE LEGGE, M.H.; OATIS JUNIOR, J.E.; WALLE, U.K. High absorption but very low bioavailability of oral resveratrol in humans. Drug Metab. Dispos., v. 32, p. 1377-1382, 2004.

65 WANG, D.; XU, Y.; LIU, W. Tissue distribution and excretion of resveratrol in rat after oral administration of Polygonum cuspidatum extract (PCE).

Phytomedicine, v. 15, p. 859-866, 2008.

66 WHYTE, L.; HUANG, Y.Y.; TORRES, K.; MEHTA, R.G. Molecular mechanisms of resveratrol action in lung cancer cells using dual protein and microarray analyses. Cancer Res., v. 67, p. 12007-12017, 2007.

67 WIEDER, T.; PROKOP, A.; BAGCI, B.; ESSMANN, F.; BERNICKE, D.; SCHUZE-OSTHOFF, K.; DÖRKEN, B.; SCHMALZ, H.G.; DANIEL, P.T.; HENZE, G. Piceatannol, a hydroxylated analog of the chemopreventive agent resveratrol, is a potent inducer of apoptosis in the lymphoma cell line BJAB and in primary, leukemic lymphoblasts. Leukemia, v. 15, p. 1735-1742, 2001.

68 WORLD HEALTH ORGANIZATION. Global status report on acohol 2004. Geneva: WHO, 2004. Disponível em:

<http://whqlibdoc. who.int/publications/2004/9241562722 (425KB).pdf>.

Acesso em: 07 mar. 2009.

69 WORLD HEALTH ORGANIZATION. WHO public hearing on harmful used of alcohol. Geneva: WHO, v. 6, 2009. Disponível em:

<http://www.who.int/substance abuse/activities/6individuals.pdf $>$. Acesso em: 07 mar. 2009.

70 YU, C.; SHIN, Y.G.; CHOW, A.; LI, Y.; KOSMEDER, J.W.; LEE, Y.S.; HIRSCHELMAN, W.H.; PEZZUTO, J.M.; MEHTA, R.G.; BREEMEN,R.B. van. Human, rat, and mouse metabolism of resveratrol. Pharm. Res., v. 19, p. 1907 - 1914, 2002. 